$$
S B
$$$$
993
$$$$
\text { - R5 }
$$$$
1852
$$ 


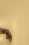







\section{9}

TH E

\section{PESTS OF THE FARM;}

BEING AN ACCOUNT OF THE VARIOUS

DEPREDATING ANIMALS, BIRDS, AND INSECTS

WHICH

ANNOY THE ANERICAN FARMER.

WITH

DIRECTIONS FOR THEIR DES'TRUCTION.

WITH ILLUSTRATIONS ON WOOD.

$$
\begin{gathered}
\text { NEW YORK: } \\
\text { C. M. S A X TON, }
\end{gathered}
$$

A GRICULTURAL BOOK PUBLISHER. 1852 .

\section{\&}

, 


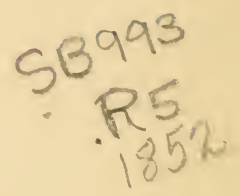

Entered according to act of Congress, in the year 1852, by C. M. SAXTON,

in the Clerk's Office of the District Court of the United States, for the Southern District of New York.

30,438

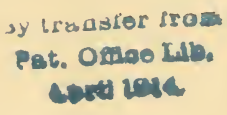

S. W. BENEDICT, Stereotyper and Printer, 16 Spruce street, $N$. $\boldsymbol{Y}$.

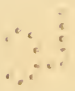




\title{
PUBLISHER'S ADVERTISEMENT.
}

The Publisher, having found the want of small, cheap Books, of acknowledged merit, on the great topics of farming economy, and meeting for those of such a class a constant demand, offers, in his Rural Handbooks, of which this is one, works calculated to fill the void.

He trusts that a discerning Public will both buy and read these little Treatises, so admirably adapted to all classes, and fitted by their size for the pocket, and thus readable at the fireside, on the road; and in short everywhere.

\author{
C. M. SAXTON, \\ Agricultural Book Publisher.
}




\section{EDITOR'S PREFACE.}

ThE title and purpose of this little book, were suggested by the English one of Richardson. Beside the name, this has little connection with that, as it is wholly American, some trifling portion only haring been taken from it. The pests of the American farm being nearly all American, it was necessary to draw its matter from American sources. The Editor is indebted mainly to Godman and Audubon for the portion relating to Quadrupeds; to Wilson, Bonaparte, Ord and Audubon for that relating to Birds; and to Harris and Miss Morris for that relating to Insects.

The matter contained in this little book is nowhere else accessible in one rolume, nor in popular shape. To obtain the information here given, many expensive ones, without this, must have been consulted; and while these circumstances should commend it to every farmer, the subject matter should command his attention and secure his interest.

A. S. 


\section{0 N T ENTS.}

\section{SECTION I.}

\section{QUADRUPEDS.}

The Wild Cat, page 8-Northern or Canadian Lynx, 9-The Skunk, 10The Weasel, 13-The Otter, 17-The American Porcupine, 18-The Mole, 19-The European Rabbit, 23-The Hare or American Rabbit, 25-The Fox, 27-Wolves, 30; the Common Wolf, 30; the Prairie or Barking Wolf, 32; the American Black Wolf, 33-The Woodchuck or Marmot, 35-The Raccoon, 37-The Black Bear, 40-Squirrels, 45; the Cat Squirrel, 45; the Black Squirrel, 45; the common Grey Squirrel, 45; the common Red Squirrel, 46; the Ground Squirrel or Chipmunk, 47-Rats, 48-Mice, 56-Ferrets, 59.

\section{SECTION II.}

\section{PREDACIOUS BIRDS.}

Predacious Birds, p. 60-The Eagle, 60-The Bald Eagle or White Headed Eagle, 61-The Sea or Gray Eagle, 64-The Crow, 65-The Raven, 69-Hawks, 70; American Sparrow Hawk, 70; the Red Tailed Hawk, 72-Owls, 72; the Barred Owl, 72; the Little Owl, 74; the Red Owl, 75; the Great Horned Owl, 75.

\section{SECTION III.}

\section{INSECTS.}

Insects, p. 76-Wire Worm, 77-Iules, 80-May Bugs, 81-Rose Bugs, 82-Pea Bug, 84-The Apple Worm, 85-The Apple tree Borer, 88-The Turnip Fly or Beetle, 89-Potato Fly, 90-Grasshoppers 
and Locusts, 91-Locusts, 92-Plant Lice, 94-Bark Lice, 96-Peach tre. Borer, 97-Caterpillars, 98; Yellow Bear Caterpillar, 98; the Salt Marsh Caterpillar, 99; Apple tree Caterpillar, 101; Lackey Cates pillar, 103-Locust tree Borers, 106-Apple, Cherry and Plum tree Caterpillars, 108; Corn Caterpillar, 111; Cut Worms, 112-The Plum Weevil or Curculio, 115-Canker Worms, 118-The Hop Caterpillar, 123-The Bee Moth, 124-The Grain Moth, 127-The Hessian Fly, 130. 


\section{THE PESTS OF THE FARN.}

Avy scientific mode of arrangement, in the treatment of such a very diversified subject as the present, would only prove a source of unnecessary toil and mystification to the practical reader. The principal living pests from whose annoyances farmers, or those holding land, whether as farmers or mere country gentlemen, are likely to suffer, are easily divisible into three great sections-viz., quadrupeds, birds, and insects. I adopt the latter term in its old and widest sense-viz., as applying not merely to insecta, but to worms, slugs, and other land molluses infesting plants and fruits. Under the first head, of Quadrupeds, will be the WILD CAT, the Skunk, the Weasel, the Otter, the Hedgehog or Porcupine, the Mole, the Rabit, the Hare, the Rat, the Mouse, the Fox, the Opossum, the Mink, the Muskrat, the Wolf, and the Raccoon. Under the second head will be Predacious Birds, such as the Eagle, the Raven, the Owl, the Kite, the Hawk, \&c., whose predatory habits tend usually towards the same quarter, and which may to a great extent be destroyed, or their ravages guarded against, in the same manner and by the same means. Under the third, will be Insects, properly so called, as Beetles, Weevils, Wasps, Flies, the WIreworm, the Turnip-fly, the Beetle, the various Caterpillars, and other ravenous larvoe; nor shall I omit some account of the aphis vastator, to whose devastation many persons attribute the loss of the potato; and, observe, I shall not confine my observations to such creatures as $I$ know to be pests, but shall further describe such as are only suspected, and also those which are calumniated, which I know not to be pests, many of which, indeed, are on the contrary servicecble, and to be regarded as friends rather than as foes, to be preserved rather than extirpated. 
SECTION I.

QUADRUPEDS.

The Wild CAT.-In form, the Wild Cat closely resembles its domesticated namesake; it is, however, more compactly built, is of larger size, and its tail is not only shorter, but blunter at the point. From the latter circumstance has arisen the not yet obsolete fable of wild, demon-like cats, being found, with hooks or spikes at the extremity of the tail; for, in the common Wild Cat, the extremity of the tail is usually destitute of hair, and is not unfrequently furnished with a hard and nail-like process, proceeding from a sort of unaccountable exposure of the last joint of the tail. The domestic cat will also occasionally become wild. This is not, as might be supposed, the descendant of the Wild Cat, but is of Egyptian origin. It will, however, breed with the Wild Cat, and I have ascertained that the progeny are fertile. The young are also fertile among themselves; and, hence, according to the admitted theory of zoologists, they are of the one species.

When the domestic cat becomes wild, it is, by many degrees, a more troublesome and more crafty enemy than the naturally wild animal. Whether naturally wild, or only having been rendered so by circumstances, however, both animals present the same characteristics of disposition, habit, and place of abode. Their prey is the same, their habitudes are the same, and, consequently, the same mode of destruction will be found to apply to both. The principal specific difference between the wild and the common Cat is the length of the intestines - those of the Wild Cat being considerably shorter.

The Wild Cat exceeds the common cat in size, standing usually upwards of eighteen inches in height. The body is shorter in proportion; the lips are always black, and the prevailing color of the fur a rusty or reddish grey. This fur will be found to make a warm and comfortable lining for winter shoes.

Now, as to the destruction of the cat, either traps or poison will effect it with facility. A steel spring-trap is best, and I prefer the square to the round form. Chain it firmly to some fixed object; bait with a dead fowl or piece of meat, smeared or rubbed with valerian. The cat is so very fond of the odor of this substance, hence familiarly termed "cat-mint," that it will go anywhere for 
the purpose of rolling upon it. The annexed cut represents the best form of trap for this purpose. You should proceed with cau-

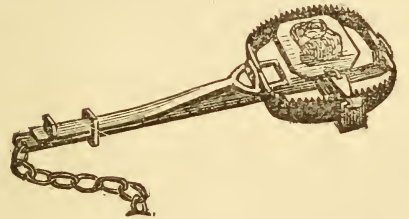

tion to release the captive felon. Should any blood be spilled upon the trap, wash it off, and change the bait every night.

Northern or Canadian Lynx.-The northern lynx is a fierce and subtle creature, exhibiting most of the traits of character which distinguish animals of the cat kind. To the smaller quadrupeds, such as rabbits, hares, lemings, \&c., it is exceedingly destructive, never leaving the vicinities they frequent until their numbers are altogether destroyed, or exceedingly thinned. But the ravages of the northern lynx are not confined to such small game; it drops from the branches of trees on the necks of deer, and clinging firmly with its sharp hooked claws, ceases not to tear at the throat and drink the blood of the animal until it sinks exhausted and expires. It attacks sheep and calves in the same manner, and preys upon wild turkeys and other birds, which it is capable of surprising, even on the tops of the highest trees.

The northern lynx is fearful of man, offers very little resistance when attacked, and is easily killed by a smart blow over the back. This animal is not often found to approach closely to settlements, though occasionally it does, when it is destructive to sheep and calves, but frequents the plains and woods where the animals on which it subsists are obtained in the greatest abundance.

The northern lynx has a large body and strong legs, and measures about three feet from the tip of its nose to the end of its tail, which is about six or seven inches long, and black for half its length towards the extremity. The head is thick and round, and the ears sharp and tipped with a tuft of black hair. There are four or five small undulating bands on the cheeks, and the labial whiskers are white. The animal is about sixteen inches high.

The general color of the northern lynx is deep reddish, marked on the flanks with small oblong spots of a reddish brown, with small round spots of the same color on the limbs. The ears are black externally, but covered by an angular space of shining $1^{*}$ 
ash color; the eyes are surrounded by a whitish circle to a black longitudinal mark above them, running from each side toward the front. The back is never marked by a black band along its middle.

In summer dress the pelage is short, the hair being brown at

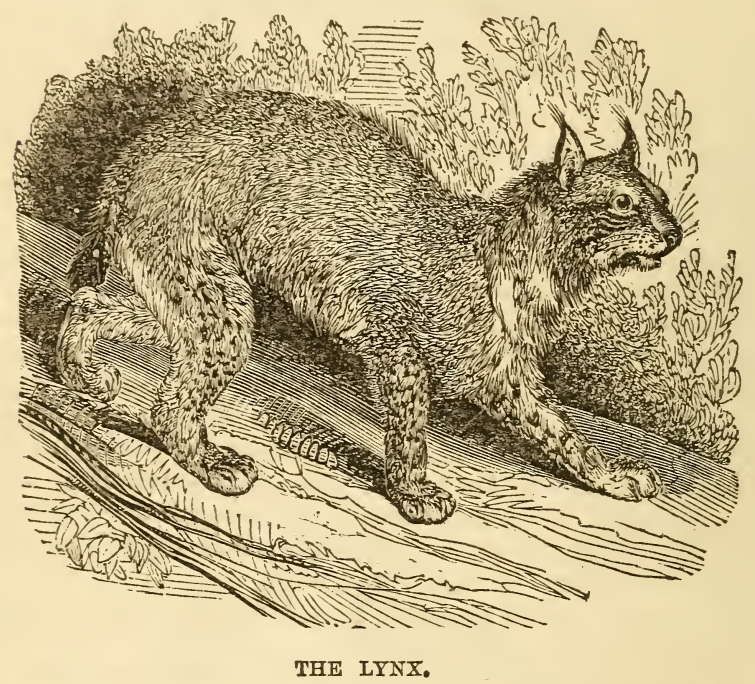

the base and of a bright red at the point. In winter the hairs are longer and all their points are whitish; the silky hairs, which are most numerous and long in winter, render the color of the animal ash or whitish, which in summer gives place to the more decided red, marked with brown spots. The lynx is to be shot or caught by traps, like the wild cat.

The Skurk.-Pedestrians, called by business or pleasure to ramble through the country during the morning or evening twilight, occasionally see a small and pretty animal a short distance before them in the path, scampering forward without appearing much alarmed, and advancing in a zig-zag or somewhat serpentine direction. Experienced persons generally delay long enough to allow this unwelcome fellow-traveler to withdraw from the path: but it often happens that a view of the animal arouses the ardor 
of the observer, who in his fondness for sport thinks not of any result but that of securing a prize. It would be more prudent to rest content with pelting this quadruped trom a safe distance, or to drive it away by shouting loudly; but almost all inexperienced persons, the first time such an opportunity occurs, rush forward with intent to run the animal down. This appears to be an easy task ; in a few moments it is almost overtaken; a few more strides, and the victim may be grasped by its long and waving tail-but that tail is now suddenly curled over the back, its pace is slackened, and in one instant the condition of thing's is entirely reversed; - the lately triumphant pursuer is eagerly flying from his intended prize, involved in an atmosphere of stench, gasping for breath, or blinded and smarting with pain, if his approach were sufficiently close to allow of his being struck in the eyes by the pestilent fluid of the skunk. Should the attack on this creature be led by a dog, and he be close at hand when the disgusting discharge is made, he runs with tail between his legs howling away, and by thrusting his nose into the soil as he retreats, tries to escape from the horrible effluvium which renders the air in the immediate vicinity of the skunk too stifling to be endured. Thus is an animal, possessed of very trifling strength and no peculiar sagacity, protected by the hand of nature against the most powerful and destructive enemies. A few glands secrete a most noisome and intolerably stinking fluid, and this scattered with peculiar force upon the body of his enemies, or even in the air, is sufficient to disarm the violence of most quadrupeds, and induce man himself rather to avoid than to seek an encounter.

The organs by which this fluid is formed, are placed near the termination of the digestive tube, and the ducts from the glands open into the rectum, by the aid of whose muscles the fluid is ejected with astonishing force, and is aimed with great accuracy, rarely missing the object, if discharged while within the proper distance. The faculty this animal possesses of annoying its enemies by the discharge of the fluid just mentioned, causes it rather to be shunned than hunted, which the value of its skin would otherwise be sure to occasion.

The skunk inhabits the whole of North America, and is also found throughout a considerable part of the southern portion of the continent. As the colored markings vary exceedingly in different individuals, it is not surprising that naturalists have made several species of this animal, though without any foundation in 
nature. All the species proposed by systematic writers are reducible to one, the subject of this article, Mephitis Americana, or American skunk.

The fetor produced by the skunk is especially characterized by all who have experienced it as suffocating or stifling, which is owing to its peculiar concentration. The predominant odor is that of muskiness, but in so condensed and aggravated a form as to render it almost insupportable, even at a considerable distance from the spot where it is first discharged. A very good idea may be formed of this stench by breaking and smelling a leaf or stalk of the plant called skunk cabbage (the Dracontium fetidum, or pathos fetidum), resembling it in every respect except in strength, which perhaps no artificial accumulation of this vile scent could ever equal.

The fluid ejected by the skunk is not merely offensive by its stench, but also in consequence of its highly stimulating and acrimonious qualities. When any of it is thrown into the eyes, it is productive of very violent and dangerous inflammation; we must suppose that this peculiar acrimony, rather than any mere offensiveness of odor, is the cause of the marked repugnance evinced by dogs, as these animals show not the slightest sign of uneasiness from the presence of the most nauseous and putrid effluvia from animal or vegetable substances, yet run howling and trying: to thrust their noses into the ground after having been exposed to this pungent perfume from the skunk.

In its extreme volatility it bears a considerable resemblance to true musk. The smallest drop is sufficient to render a garment detestable to the wearer and his companions for a great duration of time, and without any perceptible diminution of intensity. Washing, smoking, baking and burying articles of dress, and in fact every effort short of destroying the materials of which they are made, seem to be equally inefficient for its removal. This scent is not only thus enduring when the fluid is sprinkled upon clothing, but the spot where the animal is killed, or where the matter was ejected, retains it for a great length of time.

If the skunk be killed while unsuspicious of the approach of danger, or before time has been allowed for the discharge of his artillery of perfume, the animal is not in any way disagreeable, and may be approached closely or even eaten without the least unpleasantness, if the glands be carefully taken out. Its flesh, when the odorous parts have been carefully removed, is said to be 
well flavored, and resembles that of a pig considerably. It is eaten by the Indians, and occasionally by hunters, with much relish.

The skunk is most generally found in the forests or their immediate vicinity, having its den either in the hollow of an old tree or stump, or an excavation in the ground. It feeds upon the young and eggs of birds, and on small quadrupeds, wild fruits, \&c. Occasionally the skunk gains access to the poultryyard, where it does much mischief by breaking and sucking the eggs, or by killing the fowls. When resident in the vicinity of farm-houses, it remains for a long time without giving notice of its presence by emitting its offensive fluid, which proves how ridiculous is the notion that the urine of this animal is the source of its disgusting fetor ; for were this the fact, the whole country it inhabits would be rendered almost insupportable to every other creature.

We have already stated that the color of the hair is various in different individuals of this species at different seasons and periods of life. Very commonly it is of a blackish brown over the whole of the body, except on the top of the head, or immediately between the ears where there is a white spot, and the tip of the tail, also, is white. Some individuals have a slight white mark on the breast. The hairs of the tail are long and bushy, and, with the exception of their tips, are of a dark brown color. But, as heretofore stated, scarcely two of them are colored precisely in the same way. The length of a full-grown skunk is about eighteen inches, and the tail about seven, the long hair at the extremity making nearly one-half of this length.

The best way of destroying the skunk is the trap. The same form of trap recommended for the wild cat will answer, but it should be of smaller size. Box-traps have been recommended; but I have little confidence in them, and prefer the steel. A few leaves or grass should be cast orer the trap, in order to disguise its character. The skunk is not a very sagacious animal, however, and his want of cunning renders his capture, by the preceding method, very easy. If a box-trap be used at all, let it be a long one, open at both ends; cast bushes over it ; bait and trail the bait for some distance along: the path at both extremities of the trap.

The Weasel-Among the small quadrupeds inhabiting America, few are to be found equaling the weasel or ermine in 
beauty-perhaps none that excel it in the qualities of courage, graceful celerity of movement, and untiring activity. Its whole aspect inspires the beholder with an idea of its character which is well supported by its actions. The long and slender body, bright and piercing eyes, keen teeth and sharp claws, clearly show that, however diminutive the animal may appear, it is destined by nature to destroy other creatures more numerous and less powerful than those of its own race; this length and slenderness of body are accompanied by a peculiar degree of flexibility, and by a strength of limb, which, in so small an animal, may be fairly esteemed surprising. There is scarcely an opening through which its prey can enter, where the weasel cannot follow, and having once gained access, its instinctive destructiveness is only allayed when no other victim remains to be slaughtered.

In the northern parts of this continent, and the northern portions of Asia, the ermine is found in the greatest abundance; yet it is by no means limited to northern regions, since it is found throughout a vast expanse of country, reaching from the highest northern latitudes to the middle states of the Union. In the middle and eastern states it is most generally known as the weasel; farther north it is called stoat in its summer, and ermine in its winter pelage of pure white.

The habits of the ermine weasel are very analogous to those of the common weasel of Europe, and as its general configuration is so nearly similar, it is not surprising that this animal should have been confounded with the European species. This weasel frequents the barns and out-houses of plantations, and its retreat is generally well secured beneath the floors or rafters, amid accumulations of timber or stone, or in similar situations. Mice and various other depredators on the granary are the special objects of its pursuit, and the rapid multiplication of many of these devourers of grain could scarcely be sufficiently restrained, were it not that the weasel is capable of tracing them throughout their labyrinths, and possesses the disposition to destroy all that come within its reach. If the efforts of this weasel were confined to the destruction of these little depredators, we might consider it as the best friend to the husbandman; but occasionally a contribution is levied on the hen-roost, and the morning's light exhibits an universal slaughter of the poultry, whose throats are cut, or heads eaten off. It is scarcely possible to prevent such occurrences when these animals are resident in the vicinity, as they can gain access 
where few other creatures can enter; then their swiftness of motion and keen bite soon render the escape of their victims impossible.

Still it must be acknowledged that there are many situations in which the services of this little animal may bo esteemed a positive good; for such is the fecundity of many of the depredators on the grain, that nothing short of the destruction of the whole crop would ensue, were it not that the weasel is continually thinning their ranks and killing greater numbers than are required for its mere subsistence.

The disposition which makes this weasel so useful under ordinary circumstances, forbids an attempt to increase its usefulness by domestication, for the purpose of freeing our houses from mice, \&c. Notwithstanding it might be so far tamed as to take up its residence about our dwellings, it would be exceedingly dangerous to expose the lives of the inmates to the blood-thirstiness of this quadruped, which is rendered doubly dangerous from the circumstance of seeking its prey during the hours devoted by man to sleep.

The weasel is found in greater abundance on barren grounds or open plains than in the woods, which in all probability is owing to the greater number of mice that frequent the former situations.

While pursuing their prey, weasels are said to resemble little hounds running upon a trail; their tails are carried horizontally, while with eager haste and most agile movements they follow their prey by the scent. Except when in their summer dress, it is very difficult to distinguish their actions, as in winter their pure white pelage is so nearly the color of the snow, as to render it almost impossible to see them. When the weasel is hunted and closely pursued, like other species of this genus, it has the faculty of ejecting from a peculiar glandular apparatus, a fluid of a powerful musky odor; this, though it may serve to retard the pursuit of some of its enemies, is too harmless a resource to save the weasel from the hands of man.

There is but little probability of taming the weasel unless it be captured very young, and even then the period of its mildness would pass away with its early youth. When caught in a trap and subsequently kept in a cage, it exhibits every sign of the most unappeasable disposition to kill or injure every being it is able to master. Various attempts have been made to domesticate the weasel, but all without success, and frequently the restlessness and 
impatience of the animal has appeared to increase with the duration of its imprisonment.

We have mentioned that in the eastern and middle part of the United States the ermine weasel frequents out-houses, stone-heaps, piles of timber, \&c., and though capable of following its prey into small holes, does not burrow in the earth.

The ermine weasel, in its summer dress, is of a light ferruginous or chestnut-brown color over the whole of the head; this color extends in a rounded spot below the angle of the jaw; the whole back, sides, and half of the tail next the body being of the same color. The other portion of the tail is blackish, becoming gradually darker as it approaches the extremity, where it is quite black, and the hairs terminate in a point resembling that of a camel's hair pencil. The external and anterior half of the fore-legs are of the same color as the upper part of the body, and there are three small spots of white over the base of the toes of the right foot, and one on the left, over the first or shortest digit.

The under part of the animal is nearly of a pure white, beginning at the extremity of the under jaw and spreading broadly as it passes over the throat; where it forms a point on each side, almost reaching to the base of the ear. The white then narrows slightly in descending the neck, spreads broadly upon the breast, and then suddenly growing narrower, passes down the inner and posterior part of the fore legs. Thence it passes along the belly, where it is again narrowed, and then spreading out widely at the groin, it terminates at the upper and anterior part of the thigh, becoming visible for a short distance on its outside.

The fur in summer is short, soft and silky to the touch, not varying perceptibly in length except on the snout, where it is quito short, and covering the digits of the fore and hind feet, where it is rather longer than on the other parts, and conceals the nails entirely. On the tail the hairs are longer and coarser than on the rest of the body, though still soft.

The ermine weasel, in its winter pelage dress, is of a pure white over the whole head, body, and limbs; half of the tail to its extremity only retaining its black color. This white color is so pure in the northern regions as to render it almost impossible to distinguish these animals upon the snow, when the ends of their tails are not in sight. The whiteness is not always thus pure, but the fur is slightly tinted with pale yellow on the tip. 
The ear of the ermine weasel is broad at its base, and the orifice leading to the internal ear large ; the ears are not covered with fur on their posterior surface, lut by a very short down. On the superior and anterior part of the external ear, there is some hair of considerable length growing from that part of the ear which would correspond with the helix and anti-helix of the human ear, and almost covering the concha. The eyes of this animal are small and black, yet prominent, clear, and lustrous.

The fur of the ermine becomes longer, thicker, and finer in winter than in summer; this effect seems to be a general consequence of rigorous seasons on all animals, without reference to the permanence or mutability of their coloring.

To take these pests, use such square steel traps as are already described, but smaller; bait with small birds, their tails dipped in musk and aniseed; the weasel displaying as strong a predilection for this substance as the cat does for valerian.

The Common Otter varies in size-some adult specimens measuring no more than thirty-six inches in length, tail inclusive; while others, again, are to be found from four and a half to five feet long. The head of the otter is broad and flat; its muzzle is broad, rounded, and blunt; its eyes small and of a semicircular form; the body is long, rounded, and very flexible; legs short and muscular; feet furnished with fire sharp clawed toes, webbed to three-quarters of their extent; tail long, muscular, somewhat flattened, and tapering to its extremity. The color of the otter is a deep blackish brown; the sides of the head, the front of the neck, and sometimes the breast, brownish grey or dusky white. The belly is usually, but not invariably, darker than the back; the fur is short, and of two kinds; the inferior or woolly coat is exceedingly fine and close; the longer hairs are soft and glossy, those on the tail rather stiff and bristly. On either side of the nose, and just below the chin, are two small light-colored spots. So much for the appearance of the otter; we now come to its dwelling.

The native haunt of the otter is the river bank, where, amongst the reeds and sedge, it forms a deep burrow, in which it brings forth and rears its young. Its principal food is fish, which it catches with singular dexterity. It lives almost wholly in the water, and seldom leaves it except to devour its prey; on land it does not usually remain long at any one time, and the slightest alarm is sufficient to cause it to plung'e into the stream. Yet, natural as seems a watery residence to this creature, its burrow is per- 
fectly dry ; were it to become otherwise, it would be quickly abandoned. The entrance, indeed, is invariably under water, but its course then points upwards into the bank, towards the surface of the earth, and it is even provided with several lodges or apartments at different heights, into which it may retire in case of floods, throwing up the earth behind it as it proceeds into the recesses of its retreat; and when it has reached the last and most secure chamber, it opens a small hole in the roof for the admission of atmospheric air, without which the animal could not of course exist many minutes; and should the flood rise so high as to burst into this last place of refuge, the animal will open a passage through the roof, and venture forth upon land, rather than remain in a damp and muddy bed. During severe floods, otters are not unfrequently surprised at some distance from the water, and taken.

In a wild state, the otter is fierce and daring-will make a determined resistance when attacked by dogs-and being endued with no inconsiderable strength of jaw, it often punishes its assailants terribly. I have myself seen it break the fore-leg of a stout terrier.

The otter is easily rendered tame, especially if taken young, and may be taught to follow its master like a dog, and even to fish for him, cheerfully resigning its prey when taken, and dashing into the water in search of more.

The common otter is only to be regarded as a pest when fishponds or rivers are concerned. His habits are interesting, and of a gentle and inoffensive description, and his race is not so numerous as to require or deserve extirpation.

The American Porcupine.-The American Porcupine exhibits none of the long and large quills which are so conspicuous and formidable in the European species, and the short spines or prickles which are thickly set over all the superior parts of its body are covered by a long coarse hair, which almost entirely conceals them. These spines are not more than two inches and a half in length, jet form a very efficient protection to our animal against every other enemy but man. Too slow in its movements to escape by flight, on the approach of danger the porcupine places his head between his legs, and folds his body into a globular mass, erecting his pointed and barbed spines. The cunning caution of the fox, the furious violence of the wolf, and the persevering attacks of the domestic dog, are alike fruitless. At every attempt to bite the porcupine, the nose and mouth of the aggressor are severely wound- 
ed, and the pain increased by every renewed effort, as the quills of the porcupine are left sticking in the wounds, and the death of the assailant is frequently the consequence of the violent irritation and inflammation thus produced.

In the remote and unsettled parts of Pennsylvania the porcupine is still occasionally found, but south of this state it is almost unknown. According to Catesby it never was found in that direction beyond Virginia, where it was quite rare. In the Hudson's Bay country, Canada, and New England, as well as in some parts of the western states, throughout the country lying between the Rocky Mountains and the great western rivers, they are found in great abundance, and are highly prized by the aboriginals, both for the sake of their flesh and their quills, which are extensively employed as ornaments to their dresses, pipes, weapons, \&c.

The porcupine passes a great part of its time in sleep, and appears to be a solitary and sluggish animal, very seldom leaving its haunts, except in search of food, and then going but to a short distance. The bark and buds of trees, such as the willow, pine, ash, \&c., constitute its food during the winter season; in summer, various wild fruits are also eaten by it.

The porcupine is only a pest, as he may occasion the death of a valuable dog. The method of destroying him is by the gun and by traps.

The Mole.-The mole is, by most agriculturists, ranked among the most troublesome pests of their farm; while others again deny that it deserves this bad character, and are even disposed to expatiate on its utility. It is certain that the mole is of carnivorous, nay, I should perhaps say, of insectivorous habits-its food consisting chiefly of worms, slugs, snails, beetles, cockchafers, grubs, and other such creatures. In destroying these there can be no doubt but that the mole does good service to the farmer, and deserves so far to be looked on with some degree of favor. On the other hand, however, it is no less true that in forming its burrow, the mole throws up a heap of earth, known as a molehill, which is apt to interfere with the progress of the mowers. Some say that the holes also are serviceable to the soil, by throwing up the subsoil, and thus renewing the surface, but it must be at the same time admitted that this burrowing loosens and often disinters the roots of grain. Whether, therefore, this animal is to be regarded as a pest or not, depends on the opinion of the individual farmer on whose lands he may make his appearance. 
There are two kinds of moles that are pests-viz., the shrewmole and the star-nose mole.

The shrew-mole is found abundantly in North America, from Canada to Virginia; often living at no great distance from watercourses, or in dykes thrown up to protect meadows from inundation. But so far from exclusively inhabiting such places, as stated in various books, I have found them in far greater numbers at a very considerable distance from any water-course, and in high oftener than low grounds. In the country they frequent the gardens, where their subterranean galleries are sometimes productive of vexation to the farmer, especially as the animal occasionally courses along the rows of pea-rines, \&c., apparently for the purpose of feeding on their roots. This, we shall hereafter learn, is most probably an error, and we may find good reasons for believing that the shrew-mole should be considered rather as a benefactor than a depredator.

The shrew-mole burrows with great quickness, and travels under ground with much celerity : nothing can be better constructed for this purpose than its broad and strong hands, or fore-paws, armed with long and powerful claws, which are very sharp at their extremities, and slightly curved on the inside. These are thrust forward so as to be even with the extremity of the flexible snout, and the earth to be removed is pressed outwards, and at the same time thrown backwards with remarkable quickness. The soft and polished fur with which this animal is corered, preventing a great degree of friction, tends to facilitate its subterranean march.

Numerous galleries, communicating with each other, enable the shrew-mole to travel in various directions, without coming to the surface, which they appear to do very rarely, unless their progress is impeded by a piece of ground so hard as to defy their strength and perseverance. The depth of their burrows depends very materially on the character of the soil, and the situation of the place : sometimes we find them running for a great distance, at a depth of from one to three inches, and again we trace them much deeper; after following such a gallery for several yards, it occasionally communicates with another going deep into the earth.

The most remarkable circumstance connected with these burrows is the number of hills of loose dirt which are frequently formed over the surface of them. These hills of loose earth are usually found in considerable numbers, at a distance of two feet or a little more apart, being from four to six inches high, and about 
the same in diameter. I have often examined these eminences, and have never been able fully to understand how they are formed; a slight motion is observed at the surface, and presently this loose earth is seen to be worked up through a small orifice, whence, falling on all sides, by its accumulation the hills just mentioned are produced. It seems to be brought from some distance, for on breaking up the gallery, it is evident that more earth had been thrown out than could have been removed in excavating the immediately adjoining portions of the burrow. In one instance I have seen the shrew-mole show the extremity of its snout from the centre of one of these loose hills, where it had come at mid-day, as if for the purpose of enjoying the sunshine, without exposing its body to the full influence of the external air.

Under ordinary circumstances the burrows are simply ovalarched galleries, running forward either straight or in gentle curvatures, at the depth heretofore mentioned, and they are most regular in soils abounding in earth-worms. In the dry and sandy soil I have found them very irregular in direction and depth, and in the woods, uniformly leading round the roots of trees, under which large excavations are frequently to be traced. We can readily understand the object of these excarations when we recollect that the ants very often have their nests in such situations, and their larvæ or eggs constitute a favorite food of the shrew-mole. The burrows made by this animal are sometimes found to terminate under large stones, where it resorts to gather the insects, which are numerous in such situations. I have traced a burrow of this sort close to a barn wall, and then following it nearly around the whole house, have found that it passed under every large stone in its vicinity, although not directly in the general course of the gallery, the cavity being much larger beneath the stones than elsewhere.

The farorite food of the shrew-mole is the earth-worm; grubs and insects of various kinds he destroys in great quantities, and it may fairly be questioned whether the good done in this way does not more than overbalance any evil attendant on its presence. It is true that this animal is accused of eating grass roots, and roots of succulent vegetables, and may thus be productive of some mischief in gardens, but scarcely to so great a degree as to constitute a serious evil. The presence of the shrew-mole in fields of Indian corn appears to be decidedly advantageous from the destruction of great numbers of slug's and worms; but in dry seasons these animals, if numerous, may injure small grain or grasses to a consider- 
able extent, not only by the wounds they inflict on the root with their sharp claws, but by raising the sod while forming their burrows, so as to withdraw the roots from the influence of the moist soil below.

The Star-Nose Mole frequents the banks of rivulets, and the soft soil of adjacent meadows, where their burrows are most numerous, and apparently interminable ; in many places it is scarcely possible to advance a step without breaking down their galleries, by which the surface is thrown into ridges, and the surface of the green sward in no slight degree disfigured. The excavations which are most continuous, and appear to be most frequented, are placed at a short distance below the grass roots, on the banks of small streams; these are to be traced along their margins, following every inflexion, and making frequent circuits in order to pass large stones or roots of trees, to regain their usual proximity to the surface nearest the water.

The form of the burrow does not perceptibly differ from that made by the shrew-mole; but very few hills are to be found in the localities inhabited by the star-nose. The chamber-cell resembles that described in the last chapter, being a space of several inches dug out of some spot where the clay is tenacious, and the cell least exposed to injury from the weather or other accidents.

The system of dentition peculiar to this genus, would lead to the inference that the quality of its food must in some respects differ from that used by the shrew-mole; but on this point it is not easy to say more, than that as the star-nose prefers moist and low situations, and the shrew-mole is most frequently found in dry, and rather elevated spots, they feed on the larvæ and insects proper to such places, which are doubtless of dissimilar kinds. In a state of captivity both animals feed readily on flesh, either raw or cooked, and neither seem to show any fondness for, nor willingness to eat, vegetable matter.

My duty consists merely in pointing out the most efficacious method of destroying the animal: those farmers who think he should be rather protected than warred against, are not obliged to use the means I merely place within their reach.

Few dogs will kill or even mouth the mole, and if a dead one be presented to a dog, he will usually curl up his lips, and turn from it in apparent disgust. I have heard this asserted of cats also, but am not positive of the correctness of the idea, never having myself made the experiment. Traps and poison are the means 
best calculated to effect their extirpation. The ordinary mole-trap is to be obtained from any of the agricultural implement-makers, or any of the farm seed-shops. The principle of its construction depends on a spring formed of some elastic sort of twig, stuck in the ground, and bent until its other extremity is attached to the trap. The trap is placed in the mole's run, and is baited with earth-worms or a bit of raw meat. On the mole entering the trap and setting the spring at liberty, it is suddenly caught up, a noose drawn tight by the reaction of the twig, and the mole suspended by the neck.

I recently met with what I conceive to be a far more efficacious, and less troublesome mode of destroying moles.

Take a quantity of fresh worms, put them in a wooden box, with a small quantity of carbonate of barytes in powder, and let them remain for an hour or two; then find out the runs where the moles leave the fences for the land, lay in every run five or six worms, and continue doing so as long as the worms are taken away by the moles. I was infested with moles before I used this remedy, which was about fifteen years since, but have never been injured since, by giving a little attention to them in the spring.

The European Rabbit has been introduced into America, and will soon be spread widely.

The rabbit is unquestionably, when left to its own unrestrained devices, a very serious pest, but an animal which may, nevertheless, with proper management, be rendered a very considerable source of emolument, while the annoyance they have occasioned will be, at the same time, abated.

If you would have rabbits and only profit, never suffer by them; keep them in enclosures, and provide them with well-sheltered huts. The hutches should stand on dry ground, and be well ventilated. If sloping, so much the better, as this allows the wet to run, and let there be tanks placed in front to receive it. It is, when mixed with straw, valuable as manure.

Be careful while you have your rabbit-house well ventilated, that it at the same time afford them sufficient shelter, and be carefully preserved from damp. Do not give green food in a wet state; it is apt to produce the rot. If, however, a proportionate quantity of oats or other hard food be given, you need have no fear on this head. Keep them clean. Let the breeding-boxes have two apartments-one for day, and the other, furnished with a bed, for night. Do not give more food than will be consumed 
at one time, and keep the bucks apart. The doe will breed at five or six months old, and she carries her young thirty days. But the buck should not be again admitted to her until about four days after kindling, and he should be kept from her during her pregnancy, or he will cause her to cast her young. The young may be weaned at the age of from four to five weeks. The number of young produced at each litter is from ten to thirteen. If the doe be weak after parturition, she may be given beer caudle, which she will drink greedily, or warm grains, or tepid milk and water. Uats may be given daily.

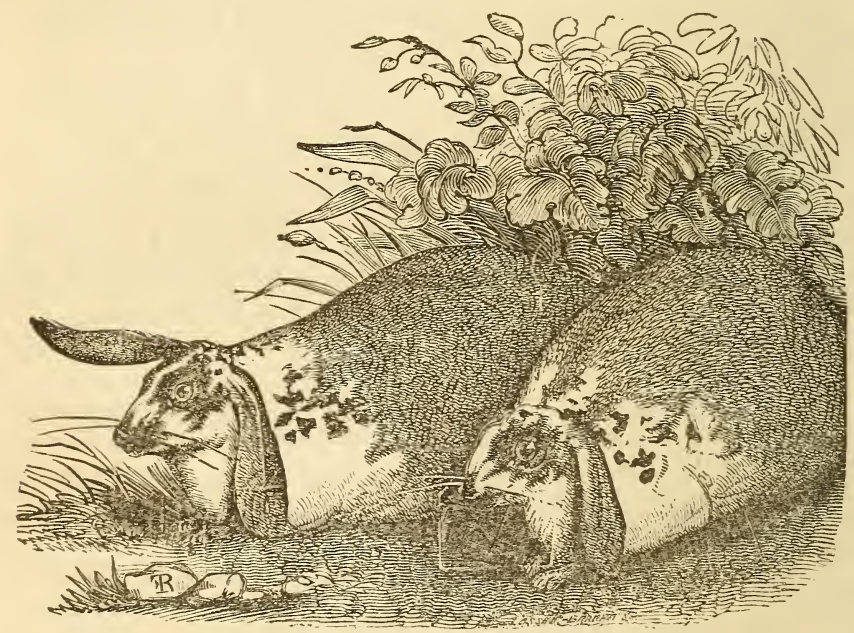

THE RABBIT.

Now as to the Rabbit in the character of a nuisance: you can never be fully on your guard against his visits, and one is destroyed vnly to make room for another. Nooses placed in the paths he is known to frequent are recommended by some.

The Rabbit commits but little mischief amongst the green crops in comparison with its ravages amongst young trees, and growing plants; and they may be prevented from injuring these by a very simple process. Mix common coal tar with equal portions of cowdung and lime, and with a brush smear the stems to the height of 
about thirty inches from the ground. The repetition of this treatment annually will effectually preserve the trees from their attacks, while the numbers of the rabbits must, of course, be kept within proper bounds by shooting or ferreting. There are also different descriptions of net used for taking rabbits, some account of which may prove useful. The fold-nets are so laid as to form an enclosure between the burrows and the usual place of feeding; into these the rabbits are driven by dogs at night. The entrance is then closed, and in the morning the rabbits are secured.

The spring-net is so constructed, as to close on pressure; it is laid round a grain or hay-stack, and numbers will be thus taken. The best mode of taking rabbits is by means of the trap. For this purpose dig a pit in the run most commonly frequented, and have it considerably wider at the bottom than at the top; across this lay a board, so nicely balanced upon a central pin, that the weight of the rabbit is sufficient to weigh it down at the extremity, while, at the same time, that weight removed, the board will resume its former position. Numbers will be taken by this method. It may be useful to remark that a rabbit is very tenacious of life, and that it will frequently, if shot in the rear, succeed in making its escape; in shooting them, aim, therefore, always for the head; if there be an earth near, and it be only struck behind, it will be sure to escape into it, and perish and rot uselessly in its burrow.

The Hare.-This is the true name, but the animal is frequently in America called the rabbit.

In various parts of the Union the American hare is exceedingly common, and large numbers are annually destroyed for the sake of their flesh and fur.

The timidity and defencelessness characteristic of the genus, are well illustrated in this species, which has no protection against its numerous enemies, and can escape by flight alone. Its peculiar color must, however, minister to its safety, as it is so similar to the general color of the soil as to require a close attention to distinguish the animal, which is usually passed without being observed by such as are not especially in search of it. Yet the swiftness and other natural advantages of the hare, insufficient to secure it from the artifices of man, or from being preyed upon by various beasts and birds, would not prevent the species from soon being extinguished, were it not for its remarkable fecundity.

During the day-time the hare remains crouched within its form, which is a mere space of the size of the animal, upon the surface 
of the ground, cleared of grass, and sheltered by some over-arching plant; or else its habitation is in the hollowed trunk of a tree, or under a collection of stones, \&c.

It is commonly at the earliest dawn, while the dew-drops still glitter on the herbage, or when the fresh verdure is concealed beneath a mantle of glistening frost, that the timorous hare ventures forth in quest of food, or courses undisturbed over the plains. Occasionally during the day, in retired and little frequented parts of the

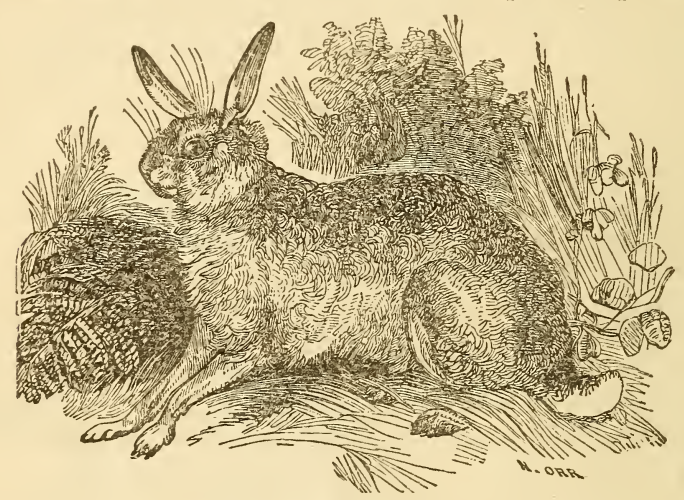

THE HARE.

country, an individual is seen to scud from the path, where it has been basking in the sun; but the best time for studying the habits of the animal is during moon-light nights, when the hare is to be seen sporting with its companions in unrestrained gambols, frisking with delighted eagerness around its mate, or busily engaged in cropping its food. On such oceasions the turnip and cabbage fields suffer severely, where these animals are numerous, though in general they are not productive of serious injury. However, when food is scarce, they do much mischief to the farmers, by destroying the bark on the young trees in the nurseries, and by cutting valuable plants.

The hare is not hunted in this country as in Europe, but is generally roused by a dog, and shot, or is caught in various snares and traps. In its movements our hare closely resembles the common hare of Europe, bounding along with great celerity, and would no doubt, when pursued, resort to the artifices of doubling, \&c., 
so well known to be used by the European animal. The American hare breeds several times during the year, and in the southern states even during the winter months, having from two to four or six at a litter.

In summer dress the American hare is dark brown on the upper part of its head, a lighter brown on the sides, and of an ash color below. The ears are wide and edged with white, tipped with brown, and very dark on their back parts; their sides approach to an ash color. The inside of the neck is slightly ferruginous; the belly and the tail are small, dark above, and white below, having the inferior surface turned up. The hind legs are corered with more white than dark hairs, and both fore and hind feet have sharp pointed, narrow, and nearly straight nails.

In winter the fur is nearly twice the length of what it is in summer, and is altogether, or very nearly, white. The weight of the animal is about seven pounds.

This species is about fourteen inches in length. The hind legs are ten inches long, by which circumstance it is most strongly distinguished from the common rabbit of Europe.

The use of coal tar, as described in reference to the rabbit, will be found equally efficacious in preserving trees from the attacks of this animal, and the painting of gate-posts and paling's of a white color at intervals, will, to a great degree, scare them from the more valuable crops. Hares are to be destroyed by the gun, by snares, traps, nets, de.

The Fox.-The Fox is a serious pest of the farm; and though of service in the destruction of other pests, yet his depredations far exceed his usefulness in the destruction of rabbits, hares, mice, moles, \&c.

There are several rarieties of foxes. Those which are mainly farm depredator's are the Red Fox and the Gray Fox.

The red fox is found throughout North America, and is the species which frequently has been thought identical with the common fox of Europe, to which it bears a resemblance sufficiently striking to mislead an incidental observer. But by the fineness of its fur, its liveliness of color, length of limbs and slenderness of body, as well as the form of its skull, it is obviously distinguished.

Red foxes are very numerous in the middle and southern states of the Union, and are everywhere notorious depredators on the poultry-yards. Their haunts are most commonly in exceedingly dense thickets, where they can scarcely be followed, even by dogs. 
Like all his kindred species, the red fox is distinguished by the possession of keen senses and great sagacity or craftiness, which enables him almost to bid defiance to traps, while his strength and swiftness of foot render it extremely difficult to capture him in the chase. Once fairly roused by the hounds, this animal dashes off with great speed, and soon far outstrips pursuit, and did he not lose the advantage of his celerity by remitting his efforts, might soon render the exertions of the sportsman nugatory. But the

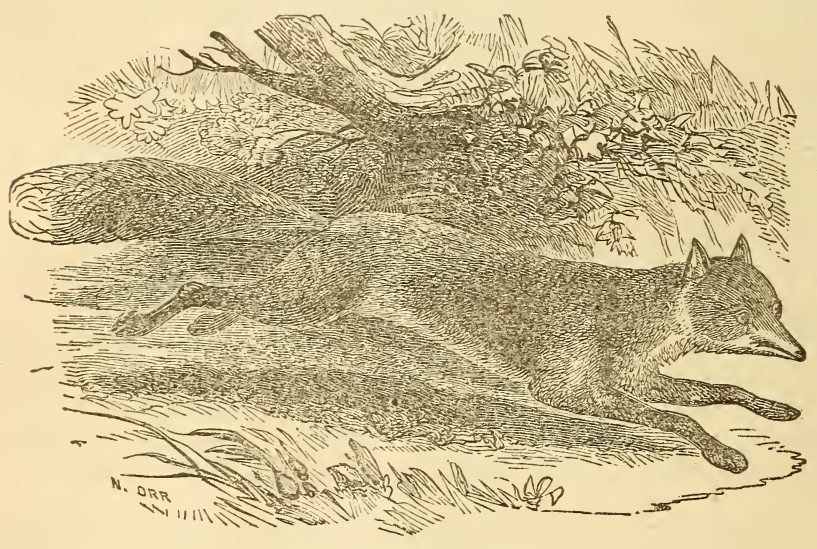

THE FOX.

persevering hounds again and again drive him to his utmost specl, and eventually wear him down, though not until a wide extent of country has been traversed, and huntsmen, horses and dogs have suffered severely from fatigue.

The general color of this fox when in full summer pelage, is bright ferruginous on the head, back and sides, but less brilliant towards the tail. Beneath the chin it is white, while the throat and neck are a dark gray, which color is continued along the anterior part of the belly in a narrower stripe that passes along the breast. The under parts of the body towards the tail are very pale red; and the anterior parts of the fore legs and feet, as well as the fronts of the inferior part of the hind legs, are 
black. The tail is very bushy, but less ferruginous than the body, the hairs being mostly terminated with black, which is more obnous toward the extremity than at the origin of the member, giving the whole a dark appearance. A few of the hairs are lighter at the end of the tail, but not sufficiently to allow us to state that it is tipped with white.

In summer the fur of the red fox is long, fine, brilliant in color, and lustrous over the whole body. In winter its length and dens?ness is considerably increased. The red fox is nearly two feet long and about eighteen inches ligh: the tail is about sixteen inches long. The peltry is of considerable value, and employed in various ways by the manufacturers.

The gray fox is very common throughout this country, and is found more immediately in the vicinity of human habitations than either of the other species. It is pursued by our sportsmen with more pleasure than the red fox, because it does not immediately forsake its haunts and run for miles in one direction, but, after various doublings, is generally lilled near the place whence it first started.

The gray fox, like all the species we described, exhibits considerable differences of color at different ages and in different states of pelage. The length of the head and body is about twenty-four, and of the tail eleven inches. The general color of the animal is grizzly, becoming gradually darker from the fore shoulders to the posterior parts of the back, produced by the intermixture of fulvous hairs with those constituting the mass of the pelage, which are thus colored; near the body the hair is rather plumbeous, then yellowish, then white, and then uniformly tipped with lustrous black. The front, from the top of the head to the edge of the orbits, is gray, while the rest of the face, from the internal angle of the eye to within half an inch of the extremity of the snout, is blackish; at the extremity on each side of the granulated black tip of the nose it is of a yellowish white. A fine line of black tipped hairs extends upwards and outwards, from half an inch below the internal angle of the eyes until it is intersected by a similar black line about half an inch beyond the external angle of the eye, thus forming a very acute triangle, whose base is on the side of the face. This blackish gray triangle, joined to the peculiar sharpness of the face, and the line produced by the black whiskers on the sides of the nose, singularly increase the appearance of slyness and cunning expressed in the physiognomy of this animal. 
The face below this triangle is white, and the latter color is continued semicireularly upon the upper part of the throat.

The under jaw is blackish, this color extending along the line of the mouth, and passing about half an inch beyond the junction of the lips at the angle. The inner surface of the ears is clothed with short light yellowish hair; their tips on the outside are blackish gray, and the whole of the rest of their posterior surface is yellow, which color descends encircling the neck, and is the only color on the anterior parts, with the exception of a white spot on the breast. The inferior parts of the body are white, tinted slightly in some individuals with faint reddish brown. The tail is thick and bushy, and the fur on the upper side is pale yellow, slightly tipped with black; the under parts are rust colored, and the end entirely black.

The most common method of destroying foxes is by hounds and. the gun. If near his burrow, to avoid the dogs, he will take to the earth, and has then to be dug out; he will sometimes ascend an inclined tree, and is then to be shot or the tree felled, when the dogs will dispatch him. He may be taken by traps and snares, but of these he is very wary. The most easy means are poisoned meats, prepared and used as pointed out for the destruction of wolves.

Wolves.-There are several varieties of wolves, viz. :-The Common Wolf, - the Prairie or Barking Wolf,-the Dusky Wolf - and the Black Wolf. The common, prairie, and black ones are those only which are pests of the farm. In all new settlements, and in the prairie region of our country, these species are dangerous enemies to the domestic animals of the farmer.

The Common Wolf.-When the aboriginal Americans first gave place to European adventurers, and the forests which had flourished for ages undisturbed, began to fall before the unsparing axe, the vicinity of the settler's lonely cabin resounded with the nightly howlings of wolves, attracted by the refuse provision usually to be found there, or by a disposition to prey upon the domestic animals. During winter, when food was most difficult to be procured, packs of these famished and ferocious creatures were ever at hand, to run down and destroy any domestic animal found wandering beyond the enclosures, which their individual or combined efforts could overcome, and the boldest house-dog' could not venture far from the door of his master without incurring the risk of being killed and devoured. The common wolf was then to be 
found in considerable numbers throughout a great extent, if not the whole of North America ; at present it is only known as a resident of the remote wooded and mountainous districts where man has just commenced to fix his abode.

The common wolf of America is considered to be the same species as the wolf of Europe, and in regard to habits and manners, gives every evidence of such an identity. Like all the wild animals of the $\log$ kind, they unite in packs to hunt down animals which individually they could not master, and during their sexual season, engage in the most furious combats with each other for the possession of the females.

The common wolf is possessed of great strength and fierceness, and is what is generally called a cruel animal, tearing the throat of his victim, drinking its blood, and rending it open for the purpose of devouring its entrails. The great strength of its jaws enables the wolf to carry off with facility an animal nearly as large as itself, and makes its bite exceedingly severe and dangerous. Aged or wounded animals, as well as the hinds and fawns of the deer, sheep, lambs, calves and pigs, are killed by these wolres, and the horse is said to be the only domestic animal which can resist them with success. They gorge with much greediness upon all sorts of carrion, which they can discover at great distances; and wherc such provision is to be obtained in great plenty, they become very fat and lose their ferocity to a singular degree.

When this wolf has been caught in a trap, and is approached by man, it is remarked to be exceedingly cowardly, and occasionally suffers itself to be beaten without offering the slightest resistance. If a dog be set upon a wolf thus captured, the assault is patiently endured so long as his master is present; but as soon as the wolf is freed from the restraint imposed by the presence of his captor, he springs upon and throttles the dog, which, if not speeclily assisted, pays the forfeit of his presumption and temerity with his life. The voice of this wolf is a prolonged and melancholy howl, which, when uttered by numerous individuals at once, is discordant and frightful. The period of gestation, \&e., in this species is in every respect analogous to that of the common dog:

Animals exposed to so much suffering from hunger, we may readily believe, are in no way exclusive in their preference of food, and these wolves may be said to feed on every creature they can master, or on the remains of any animal left by the natives.

The common wolf is about four feet and a half in length, 
including the tail, which is rather more than a foot long. The height, before, is two feet three inches; behind, it is two feet four inches. The tail is bushy and bending downwards, having upon it hairs upwards of five inches in length.

The general color of this wolf is reddish brown, intermixed with ferruginous and black; but a great variety is to be observed in the coloring of the wolf, as found in the northern, middle, and southern regions, exhibiting gradations from grizzly white to pure black.

The Prairie or Barking Wolf.-This wolf frequents the prairies or natural meadows of the west, where troops or packs containing a considerable number of individuals are frequently seen following in the train of a herd of buffalo or deer, for the purpose of preying on such as may die from disease, or in consequence of wounds inflicted by the hunters. At night they also approach the encampments of travelers, whom they sometimes follow for the sake of the carcasses of animals which are relinquished, and by their discordant howlings, close to the tents, effectually banish sleep from those who are unaccustomed to their noise. According to Say's observation they are more numerous than any of the other wolves which are found in North America.

The barking wolf closely resembles the domestic dog of the Indians in appearance, and is remarkably active and intelligent. Like the common wolf, the individuals of this species frequently unite to run down deer, or a buffalo calf which has been separated from the herd, though it requires the fullest exercise of all their speed, sagacity and strength, to succeed in this chase. They are very often exposed to great distress from want of food, and in this state of famine are under the necessity of filling their stomachs with wild plums, or other fruits no less indigestible, in order to allay in some degree the inordinate sensations of hunger.

This wolf barks in such a manner as to resemble the domestic dog. very distinctly; the first two or three notes are not to be distinguished from those produced by a small terrier, but differs from that of the dog by adding to these sounds a lengthened scream.

The barking wolf is about three feet and a-half in length, of which the tail forms thirteen and a-half inches, exclusive of the hair at its extremity. The ears are four inches long from the top of the head, and the distance from the anterior canthus of the eye to the end of the snout is three inches and three-fourths.

The general color of the barking wolf is cinerious, or gray intermingled with black, and dull fulvous or cinnamon above. The 
hair is of a dusky lead color at base, of a dull cinnamon in the middle of its length, and gray or black at tip, being of greater length along the middle of the back and other parts of the body. The ears are erect and rounded at tip, having the hair on the back part of a cinnamon color, and dark plumbeous at base, while that on the inside is gray.

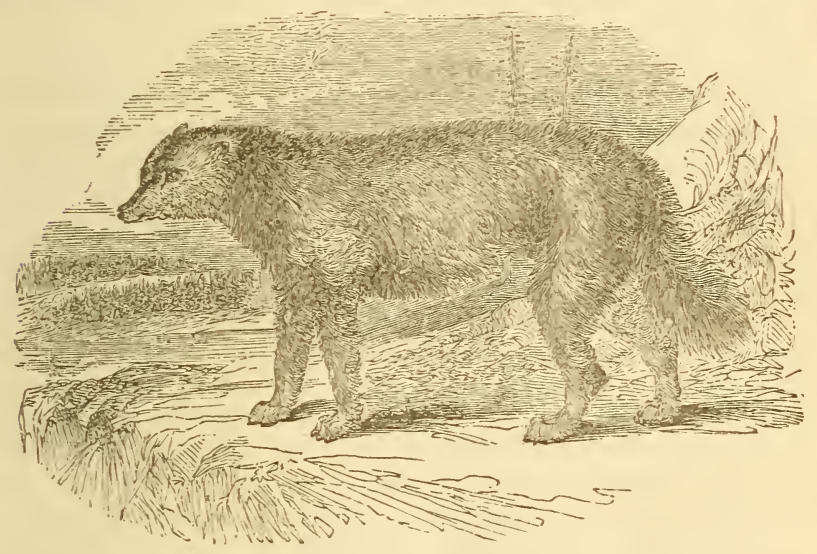

THE BLACK WOLF。

The American Black Wolf.-The American black wolf, although less common than the other varieties, is considered more dangerous and ferocious, sometimes making sad havoc among sheep and lambs. It is found more or less abundant throughout the wooded districts of the Canadas, the northern states, and of the entire Alleghany range, to their termination in Georgia.

The length of this animal is about five feet eight inches, of which the tail occupies one foot eight inches; the hejght at the fore shoulders about two feet three inches, and the girth of the body about two feet seven inches. The general color of the body is brownish-black, somewhat mottled with darker shades; the belly much lighter, with a broad stripe of black, undefined at the edges, running up the breast; the back blackish, very slightly mottled with white, caused by the intermixture of different hairs; the body is corered with a soft, thick down, light gray at the roots, 
and brownish gray at the end; besides this fur, there is likewise a longer hair which is the general color of the animal; this hair on the back is white at the roots, then black, then pure white, then black again at the tip, giving a speckled appearance to the back. The tail is large and bushy; the hair long, loose, and nearly black, as also is the throat and breast. The feet and legs are black; the hair on the front of the legs close, bristly, and shining. The head is black with the face covered with short, close hair; the nose pointed, small, and black ; the ears short, pointed, and upright.

The black wolf is much stronger than a dog of the same size, and his mode of biting is very different from that of a dog. Instead of retaining his hold, like a dog, when he seizes his enemy, he bites by repeated snaps, given, however, with great force, often lacerating the flesh a foot or more to each jerk. Like all carnivorous animals, his thirst for blood is irresistible, and he often kills his rictim without devouring the carcass, drinking the blood, the only part agreeable to his palate. When pressed with hunger, he destroys every other creature he can master, and it is believed that, during the year, he consumes at least thirty times his own weight of animal food, which, in cultivated countries, renders his injurious character more apparent, from the large number of domestic animals he necessarily must slay. In winter, when the ground is covered with snow, and he finds his prey to be scarce in his natural haunts, he becomes exceedingly bold, intrudes into the sheep-folds and pig-sties, and even into villages or populous towns, in quest of food.

The ordinary method of capturing wolves is in winter, by means of a steel trap. It has been found, however, that the most successful method of destroying them is, to drug small sausages with strychnine, or nux vomica, and hang them on the boughs of trees, at such a height, that the wolf must leap to obtain them. Under these circumstances the animal swallows the bait at once, and has not time to find out that it contains any suspicious admixture, which he often does, if the poison be applied to the carcasses of sheep, horses, \&c. Another mode of poisoning them is this : The kernels of nux vomica are grated or powdered, then mixed up with three or four times their bulk of fat or grease, and honey (wolves are very fond of the latter), and made into balls about as large as a hen's egg. These are placed in the woods, covered with a piece of flesh or tripe, and some offal is hung on a tree near the spot, to 
attract the wolves by its scent. The poison once taken is sure to prove fatal, before the animals can proceed many rods.

The common and the black wolf are usually destroyed in two ways. When annoyed by them the farmers frequently unite, and by a general battue destroy them. This is effected, by forming about the observed retreats of the wolf, a large circle of two or three miles in diameter. The hunters gradually close in on the point of hiding, and hedge the wolf in, when he is easily destroyed.

A frequent means of destruction is a deep pit. This is dug so deep as to prevent the wolf from jumping out, once he is in. The pit is baited with a dead sheep or animal or carrion. The wolf jumps down for his prey, gorges himself, and then seeks to escape, but in vain. His howlings soon inform the farmer or hunter of his imprisonment, when the pit is visited and the prisoner killed.

The prairie wolf is too sagacious to be caught by traps. He may be poisoned like the other varieties. He is frequently shot. Occupying the open prairie he is good game for the grayhound, and is often chased by him. Once the grayhound sights him, if in the open prairie, the wolf must be near the cover of a wood, or he has not the least chance of an escape. Being small, a brace of grayhounds soon dispatch him. He may be taken in pits, but is very shy of them.

The WoODCHUCK.-This animal is the arctomys monax or marmot. Among the country people it bears the name of woodchuck and ground-hog, the latter being expressive of its habits of burrowing and peculiar voracity.

The woodchuck is the cause of great injury, especially to the farmers engaged in the cultivation of clover, as their numbers become very considerable, and the quantity of herbage they consume is really surprising. They are more capable of doing mischief from the circumstance of their extreme vigilance and acute sense of hearing, as well as from the security afforded them by their extensive subterranean dwellings.

When about to make an inroad upon a clover-field, all the woodchucks resident in the vicinity quietly and cautiously steal toward the spot, being farored in their march by their gray color, which is not easily distinguished. While the main body are actively engaged in cropping the clover-heads and gorging their ample cheek-pouches, one or more individuals remain at some dis- 
tance in the rear as sentinels. These watchmen sit erect, with their fore-paws held close to their breast, and their heads slightly inclined to eatch every sound which may move the air. Their extreme sensibility of ear enables them to distinguish the approach of an enemy long before he is sufficiently near to be dangerous, and the instant the sentinel takes alarm he gives a clear shrill whistle, which immediately disperses the troop in every direction, and they speedily take refuge in their deepest caves. The time at which such incursions are made is generally about mid-day, when

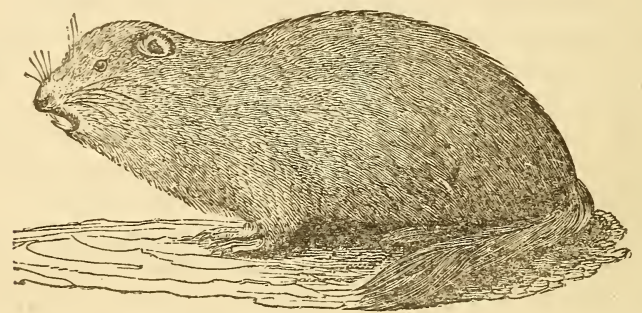

THE WOODCHUCK.

they are less liable to be interrupted than at any other period, either by human or brute enemies.

The habitations of the woodchuck are formed by burrowing into banks, the sides of hills, or other similar situations, by which the access of water is prevented. In forming the burrow, where the ground is soft, the fore-paws are the principal agents; the strength of the animal's fore limbs is very great. Where the soil is hard and compact, the long cutting teeth are very freely and efficiently employed, and we have been surprised to see large stones and lumps of hardened clay dug out in this way.

The burrows extend to great distances under ground, and terminate in various chambers, according to the number of inhabitants. In these, very comfortable beds are made by the woodchuck, of dry leaves, grass, or any soft dry rubbish to be collected. It is really surprising to see the vast quantity of such material an individual will cram into his mouth to carry off for this purpose. He firsts grasps with the teeth as much as he possibly can; then sitting erect, with both fore-paws he stuffs the mass projecting on each side deeper into the mouth, and having arranged it satisfactorily, takes up successive portions, which are treated in like man- 
ner; during the whole time the head is moved up and down to aid in filling the mouth to the very utmost. This is repeated until every fragment at hand is collected, and the whole transferred to the sleeping apartment, into which the woodchuck retires towards the decline of the day, and remains there until the morning is far advanced. At some seasons of the year the woodchuck is seen out on moonlight nights at a considerable distance from the burrow, either in search of better pasture or looking for a mate; on such occasions, when attacked by a dog, the woodehuck makes battle, and when the individual is full-grown, his bite is very severê. The teeth of the dog give him vast superiority in the combat, as when once he seizes, he is sure of the hold until the parts bitten are torn through, while the woodchuck can merely pinch his foreteeth together, and must renew his attempts very frequently. The fight is also soon ended by the dog seizing the woodchuck by the small of the back, and crushing the spine so as to disable his antagonist effectually.

The woodchuck is to be destroyed by dogs. The most of farm dogs are very fond of pursuing them. If the woolchuck escape to his hole, the dog will readily dig him out. But a speedier way is to smoke his hole, and drive him out, when the dog readily catches and destroys him. He is easily shot, and may be handily taken in traps.

The RAccoox.-There are few parts of the American continent in which the Racoon has not, at some periol, been found native, from the borders of Nootka Sound to the forests of Mexico, and still more southern regions.

Were we to form an opinion of this animal's character solely from external appearances, the mingled expression of sagacity and innocence exhibited in his aspect, his personal neatness and gentle movements, might all incline us tọ believe that he possessed a guileless and placable disposition. But in this, as in most other cases, where judgments are formed without sufficient examination, we should be in error, and find, that to the capricious mischievousness of the monkey, the racoon adds a blood-thirsty and vindictive spirit, peculiarly his own. In the wild state, this sanguinary appetite frequently leads to his own destruction, which his nocturnal habits might otherwise avert; but as he slaughters the tenants of the poultry-yard with indiscriminate ferocity, the vengeance of the plundered farmer speedily retaliates on him the death so liberally dealt among the feathered victims. This destructive propensity of 
the raccoon is more remarkable, when we observe that his teeth are not unsuited for eating fruits. When he destroys wild or domestieated birds, he puts to death a great number without consuming any part of them, except the head, or the blood which is sucked from the neck.

Being peculiarly fond of sweet substances, the raccoon is occasionally very destructive to plantations of sugar cane, and of Indian corn. While the ear of the Indian corn is still young, soft and tender, "in the milk," it is very sweet, and is then eagerly sought by the raccoons; troops of them frequently enter fields of maize, and in one night commit extensive depredations, both by the quantity of grain they consume, and from the number of stalks they break down by their weight.

The raccoon is an excellent climber, and his strong sharp claws effectually secure him from being shaken off the branches of trees. In fact, so tenaciously does this animal hold to any surface upon which it can make an impression with its claws, that it requires a considerable exertion of a man's strength to drag him off; and as long as even a single foot remains attached, he continues to cling with great force.

The conical form of the head, and the very pointed and flexible character of the muzzle or snout, are of great importance in aiding the raccoon to examine every vacuity and crevice to which he gains access; nor does he neglect any opportunity of using his natural advantages, but explores every nook and cranny, with the most persevering diligence and attention, greedily feeding on spiders, worms, or other insects which are discovered by the scrutiny. Where the opening is too small to give admittance to his nose, he employs his fore-paws, and shifts his position or turns his paws sidewise, in order to facilitate their introduction and effect his purpose. This disposition to feed on the grubs or larvæ of insects must render this animal of considerable utility in forest lands, in consequence of the great numbers of injurious and destructive insects he consumes. He is also said to catch frogs with considerable address, by slily creeping up, and then springing on them, so as to grasp them with both paws.

The size of the raccoon varies with the age and sex of the individual. A full grown male may be stated to have the body a foot, or a few inches more, in length ; the highest part of the back is about a foot from the ground, while the highest part of the shoulder is ten inches. The head is about five, and the tail rather 
more than eight inches long. The female is larger than the male in every respect, at least such is the fact in relation to the raccoons now in my possession, which, however, have not yet attained their full growth. They are of the same age, and the female is strongly distinguished from the male by the black markings on all parts of the body being more purely black, and the fur and hair longer, thicker, and more glossy than that of the male; these peculiarities, in addition to her greater size, uniformly lead strangers to suppose this individual to be the male, instead of the female. The pelage of the male is not only less purely black at the extremities of the hairs, but there is a much greater intermixture of fawn-colored hair than in the female, giving more of a rusty appearance to the whole surface of his body. A young raccoon of thirty days old is about the size of a common cat of a year old, though the greater length of its legs and the bushiness of its pelage, make it at first sight appear much larger.

The general color of the body is a blackish gray, which is paler on the under part of the body, and has over considerable part of the neck, back and sides, some fawn or light rust-colored hair intermixed. The general gray color is owing to the manner in which the hairs are alternately ringed with black and dingy white. The tail is very thickly corered with hair, and is marked by five or six black rings round it, on a yellowish white ground.

The head, which is about five inches long, is very triangular, and from its pointed snout reminds us of the aspect of the fox : the snout terminates in a smooth and shining black membrane, through which the nostrils open, having the slit to rise slightly at the sides. The nose is prolonged considerably beyond the upper jaw, and this, together with its great flexibility, gives the animal great advantages in exploring little crevices and crannies for insects, \&c. The pupils of the eyes are round; the ears are oval, or rather elliptic, and of a yellowish white color on their extremities and anterior edges. The face is whitish, in front, but there is a black patch surrounding the eye, that descends entirely to the lower jaw, over the posterior part of which it is diffused, and a black line running from the top of the head down the middle of the face, ending below the eyes. The rest of the hair between the eyes, the ears, and eye-brows, is almost entirely white, and discted downwards. The hair on the muzzle is usually very short; on the feet also, and on one-half of the legs ; the short hair of the 
fect and legs is of a dirty whitish color. The whiskers on the upper lip are long and strong.

All the feet have five toes each, terminated by strong curved and pointed claws; and each foot is furnished with five thick and very alastic tubercles beneath. The first toe or thumb of the forefoot is the shortest of all; the little or external finger is next in length, and then the fore-finger; the remaining two are equal. The first tubercle, which is a very strong one, is situated near the wrist; the second is at the base of the little finger; the third at the root of the inner finger or thumb; the fourth opposite the second digit, and the fifth opposite the two longest. The hind feet are throughout similar, except that the first tubercle is farther distant from the heel.

The pelage of the raccoon is subject to considerable variations of color at different periods of life, and in different individuals. The rings on the tail and the patches around the eyes are, however, uniform and constant. The tail of the raccoon is not affected by the coldest weather; hence this quadruped is never known to gnaw his tail, as has been observed of animals closely allied to it in configuration and habits.

As the habits of the raccoon are nocturnal he is not easily shot. He may readily be taken by snares and traps. He is frequently hunted at night in August and September, during the period of green corn, with dog's. He escapes to a tree, which is cut down, and the dogs seize him as he comes to the ground.

The Black Bear.-There are three varieties of the Bear in America, viz. : the American or Black Bear, the Grizzly Bear, and the Polar Bear. The Black Bear alone is a pest of the farm.

This bear is found throughout North America, from the shores of the Arctic Sea to its most southern extremity.

The black bear, under ordinary circumstances, is not remarkably ferocious, nor is he in the habit of attacking man without provocation. But when wounded, he turns on the aggressor with great fury, and defends himself desperately. This disposition is more fully manifested during the coupling season, because the males are then highly excited, and are not so inert and clumsy as in the autumn, when they are exceedingly fat.

When the winters are severe at the north, and they find a difficulty of procuring food, they travel to the southern regions in considerable bodies.

The sight and hearing appear to be the most acute of the 
senses in this bear. Although he kills many small animals, he does not follow them by the smell. When he walks, his gait is heavy and apparently awkward, and when running is not much less so, but his strength of body enables him to move with considerable celerity, and for a long time.

The females bring forth their young in the winter time, and exhibit for them a degree of attachment which nothing can surpass. They usually have two cubs, which are suckled until they are well grown. The fondness existing between the mother and cubs seems to be mutual, and no danger can separate her from them, nor anything, short of death itself, induce her to forsake them.

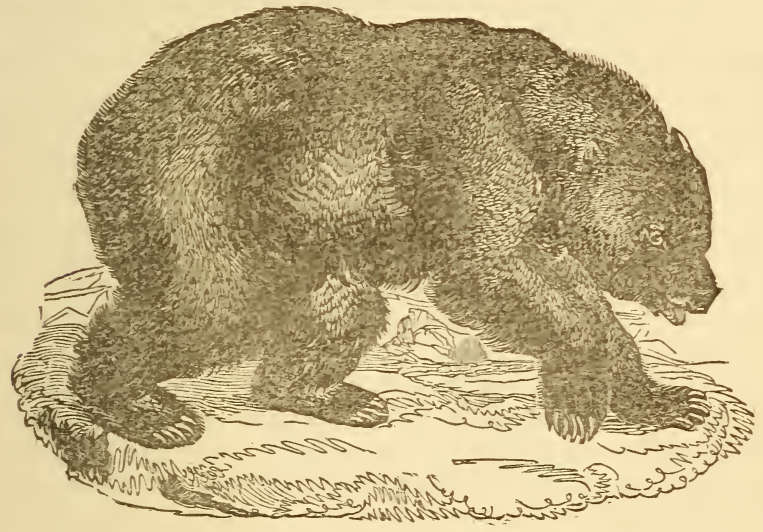

THE BEAR.

Black bears are still numerous in the wooded and thinly settled parts of the States of the Union, and where their farorite food is plenteous they grow to a great size, and afford a large quantity of oil.

The food of this animal is principally grapes, plums, whortleberries, persimmons, bramble and other berries; they are also particularly fond of the acorns of the live oak. They are also very fond of the different kinds of nuts and esculent roots, and often ramble to great distances from their dens in search of whort'eberries, mulberries, and indeed all sweet flavored and spicy fruits: birds, small quadrupeds, insects, and eggs, are also devoured by 
them whenever they can be obtained. They are occasionally very injurious to the frontier settlers, by their incursions in search of potatoes and young corn, both of which are favorite articles of food; their claws enable them to do great mischief in potato grounds, as they can dig up a large number in a very short time, and where the bears are numerous their ravages are occasionally very extensive.

In the north, the flesh of the black bear is fittest for the table after the middle of July, when the berries begin to ripen, though some berries impart a very disagreeable flavor to their flesh. They remain in good condition until the following January or February; late in the spring they are much emaciated, and their flesh is dry and disagreeable in consequence of their long fasting through the season of their torpidity. Their flesh is also rendered rank and disagreeable by feeding on herring spawn, which they seek and devour with greediness, whenever it is to be obtained. The southern Indians kill great numbers of these bears at all seasons of the year, but no inducement can be offered to prevent them from singeing off the hair of all that are in grood condition for eating, as the flesh of the bear is as much spoiled by skinning as pork would be; the skins these people bring the traders are consequently only such as are obtained from bears that are too poor to be eaten.

The black bear is in fact very indiscriminate in his feeding; and though suited by nature for the almost exclusive consumption of vegetable food, yet refuses scarcely anything when pressed by hunger. He is moreover voracious as well as indiscriminate in satisfying his appetite, and frequently gorges until his stomach loathes and rejects its contents. He seeks, with great assiduity, for the larvæ or grub-worms of various insects, and exerts a surprising degree of strength in turning over large trunks of fallen trees, which, whenever sufficiently decayed to admit of it, he tears to pieces in search of worms.

The usual residence of the black bear is in the most remote and secluded parts of the forest, where his den is either in the hollow of some lecayed tree, or in a cavern formed among the rocks. To this place he retires when his hunger is appeased, and in the winter he lies coiled up there during the long period of his torpidity. The female of the black bear, during the period of gestation, which commences in the month of October, and continues for 
about one hundred and twelve days, leads a retired and concealed life.

In the northern parts of this continent, the subterraneous retreats of the black bear may be readily discovered by the mist which uniformly hangs about the entrance of the den, as the animal's heat and breathing prevent the mouth of the cave from being entirely closed, however deep the snow may be. As the black bear usually retires to his winter quarters before any quantity of snow has fillen, and does not again venture abroad, if undisturbed, until the end of March or beginning of April, he must consequently spend at least four months in a state of torpidity, and without obtaining food. It is therefore not surprising that, although the bear goes into his winter quarters in a state of excessive fatness, he should come out in the spring of the year extremely emaciated.

The northern Indians occasionally destroy the bear by blocking up the mouth of the cave with logs of wood, and then breaking: open the top of it, kill the animal with a spear or gun. Sometimes they throw a noose round his neck, draw him up to the top of the hole, and kill him with a hatchet.

The black bear is occasionally captured in large and strong steel traps, well secured by a chain to a neighboring tree, and laid in a path over which a freshly-killed carcass has been drawn along;or he is taken in a noose suspended from a strong sapling. $\Lambda$ common mode of hunting this animal is to follow him with two or three well-trained dog's. When he finds that he is pursued, he generally pushes directly forward for eight or ten miles, or farther, if not overtaken; as the dog's come up with him their repeated attacks cause him to turn for the purpose of striking at them, and if they do not dexterously avoid his blows they will be killed, as he strikes with very great force. To aroid the vexation produced by the dogs, he mounts a tree, ascending for twenty or thirty feet, but is allowed very little rest, for the hunter now approaching, he throws himself to the earth, and hurries onwards, being still pursued and worried by the dog's. Again he is obliged to take refuge in a tree, and sometimes climbs as near as possible to the top, endeavoring to conceal himself among the foliage. The hunter now strikes against the trunk of the tree, as if engaged in cutting it down; the poor bear soon betrays his hiding-place, and slipping to the end of the longest branch, gathers his body up, and drops from a vast height to the ground, whence he often appears to re- 
bound for several feet, and then runs off as actively as he can. At length, worn out by frequently repeated exertions to escape, he is finally shot, while attempting to screen himself by aid of the trunk of a tree, or while employed in resisting the attacks of the dogs.

Among other modes of lilling the black bear the Indians employ a trap composed of logs, which, when the animal attempts to remove the bait, either falls on his body and kills him outright, or secures him until he is put to death by the proprietor of the snare.

The black bear, like all the species of this genus, is very tenacious of life, and seldom falls unless shot through the brain or heart. An experienced hunter never advances on a bear that has fallen, without first stopping to load his rifle, as the beast frequently recovers to a considerable degree, and would then be a most dangerous adversary. The skull of the bear appears actually to be almost impenetrable, and a rifle ball, fired at a distance of ninety-six yards, has been flattened against it, without appearing to do any material injury to the bone. The best place to direct blows against the bear is upon his snout; when struck elsewhere, his dense, woolly coat, thick hide and robust muscles, render manual violence almost entirely unavailing.

When the bear is merely wounded, it is very dangerous to attempt to kill him with such a weapon as a knife or tomahawk, or indeed anything which may bring one within his reach. In this way hunters and others have paid very dearly for their rashness, and barely escaped with their lives.

The black bear, in common with other species of this genus, endeavors to suffocate an adversary by violently hugging and compreșsing its chest. A man might end such a struggle in a few instants, if one hand be sufficiently at liberty to grasp the throat of the animal with the thumb and fingers, externally, just at the root of the tongue, as a slight degree of compression there will generally suffice to produce a spasm of the glottis, that will soon suffocate it beyond the power of offering resistance or doing injury.

The black bear differs from other species of the genus by having the nose and forehead nearly on the same line, though the forehead is slightly prominent. The palms of the hands and soles of the feet are very short, and the whole body is covered with long, shining, straight black hair, which is by no means harsh to the touch. The sides of the face are marked with fawn color, and a small spot of the same exists in some individuals in front of the 
eye; others have the muzzle of a clear light yellow, with a white line commencing on the root of the nose and reaching to each side of the angle of the mouth. This continues over the cheek to a large white space, mixed with a slight fawn color, covering the whole of the throat, whence a narrow line descends upon the breast.

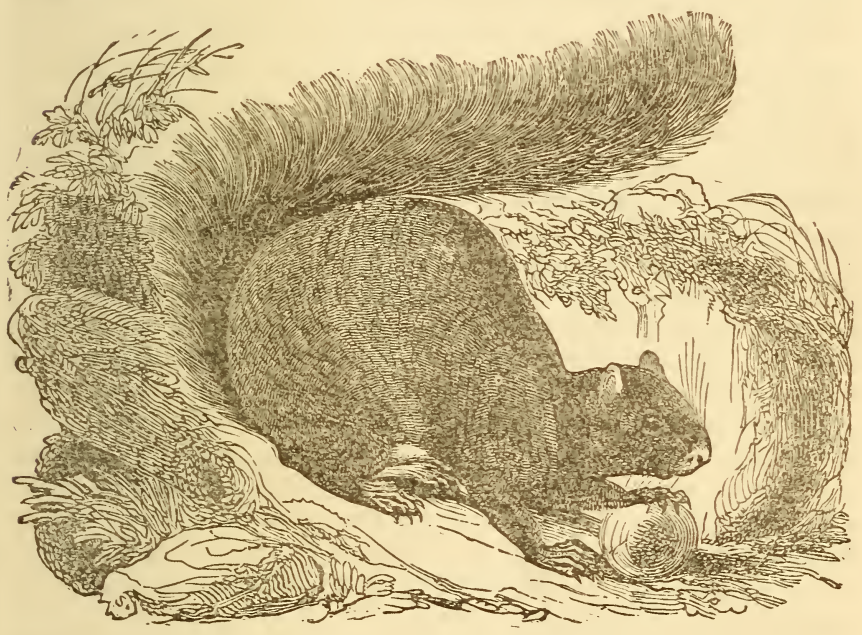

THE SQUIRREL.

SQUrRRELs.-There are several varieties of Squirrels.

The Fox Squirrel is common in the southern States, and is not troublesome.

The Cat Squirrel is found in great abundance throughout the oak and chesnut forests of this country, and is not to any extent a depredator.

The Black Squirrel is very common, and at times very destructive in the Indian corn fields. The black squirrel, in summer, is rather gray on the back and sides, though the whole color of the body is black, with some gray interspersed, and of a reddish brown on the under parts. In winter the color is a pure black all over the body.

The Common Gray Squirrel.-This species, still exceedingly 
common throughout the United States, was once so excessively multiplied as to be a scourge to the inhabitants, not only consuming their grain, but exhausting the public treasury by the amount of premiums given for their destruction.

The gray squirrel prefers the oak, hickory and chesnut woods, where it finds a copious supply of nuts and mast, of which it provides large hoards for the winter. Their nests are placed chiefly in tall oak trees at the forks of the branches; these nests are very comfortable, being thickly covered and lined with dried leaves. During cold weather the squirrels seldom leave these snug retreats, except for the purpose of visiting their store-houses, and obtaining a supply of provisions. It has been observed that the approach of uncommonly cold weather is foretold when these squirrels are seen out in unusual numbers, gathering a larger stock of provisions, lest their magazines should fail. This, however, is not an infallible sign, at least in vicinities where many hogs are allowed to roam at large, as these keen-nosed brutes are very expert at discovering the winter hoards of the squirrel, which they immediately appropriate to their own use.

If the gray squirrels confined themselves to the diet afforded by the forest trees, the farmers would profit considerably thereby. But, having once tasted the sweetness of Indian corn and other cultivated grains, they leave acorns and such coarse fare to the hogs, while they invade the corn fields, and carry off and destroy a very large quantity. This species is remarkable among all our squirrels for its beauty and activity.

The gray squirrel varies considerably in color, but is most commonly of a fine bluish gray, mingled with a slight golden hue. This golden color is especially obvious on the head, along the sides, where the white hair of the belly approaches the gray of the sides, and on the anterior part of the fore and superior part of the hind feet, where it is very rich and deep. This mark on the hind feet is very permanent, and evident even in those varieties which differ inost from the common color. There is one specimen in the Philadelphia Museum of a light brownish red on all the superior parts of the body.

The Common Red Squirrel, or Hudson's Bay Squirrel of Naturalists.-This beautiful species is very common in the northern and western parts of this country, and, where seldom disturbed, are so fearless as to allow themselves to be approached almost within reach. 
The common red squirrel is, perhaps, more remarkable for its neatness and beauty than any of its kindred species, which, in habits and manners, it closely resembles. It is between seven and eight inches long, having a tail five inches in length. Its whiskers are very long and black; the superior parts of the body are of a reddish brown color, varying in intensity, and shaded with black. On the inferior parts the general color is a tarnished or yellowish white; the under part of the head and front of the fore limbs are reddish brown, like the back; the insides of the thighs are colored like the belly; on each flank there is a distinctly marked black line, separating the colors of the back and belly. The tail is of a reddish brown color, and is very beautiful.

The red squirrel is a great pest in orchards. He will frequently destroy a hundred pears in a day to get the seeds, which alone he eats.

The Ground Squirrel (commonly called the Chipmunk, Hacky or Hackee, Ground, or Striped Squirrel).-Few persons have traveled without becoming acquainted with this pretty animal, which, though very different in its general appearance from its kindred tenanting the lofty forest-trees, still approaches to them so closely in personal beauty and activity, as always to command the attention of the most incidental observer.

This squirrel is most generally seen scudding along the lower rails of the common zig-zag or "Virginia" fences, which afford him at once a pleasant and secure path, as in a few turns he finds a safe hiding-place behind the projecting angles, or enters his burrow undiscovered. When no fence is near, or his retreat is cut off, after having been out in search of food, he becomes exceedingly alarmed, and runs up the nearest tree, uttering a very shrill cry or whistle, indicative of his distress, and it is in this situation that he is most frequently made captive by his persecuting enemies, the mischievous school-boys.

The ground squirrel makes his burrow generally near the roots of trees, along the course of fences and old walls, or in banks adjacent to forests, whence he obtains his principal supplies of food. The burrows frequently extend to very considerable distances, having several galleries or lateral excavations, in which provisions are stored for winter use. The burrow has always two openings, which are usually far distant from each other; it very rarely happens that the animal is dug out, unless it be accidentally during the winter season. 
The ground squirrel is rather more than five inches in length, from the nose to the root of the tail ; the last is about two inches and a half long. The general color of the head and upper parts of the body is reddish brown, all the hairs on these parts being gray at base. The eyelids are whitish, and from the external angle of each eye a black line runs towards the ear, while on each cheek there is a reddish brown line. The short rounded ears are covered with fine hairs, which are on the outside of a reddish brown color, and within of a whitish gray. The upper part of the neck, shoulders, and base of the hair on the back, are of a gray brown, mingled with whitish.

On the back there are five longitudinal black bands, which are at their posterior parts bordered slightly with red. The middle one begins at the back of the head, the two lateral ones on the shoulders; they all terminate at the rump, whose color is reddish. On each side two white separate the lateral black bands. The lower part of the flanks and sides of the neck are of a paler red; the exterior of the fore feet is of a grayish yellow ; the thighs and hind feet are red above. The upper lip, the chin, throat, belly, and internal face of the limbs are of a dirty brown. The tail is reddish at its base, blackish below, and has an edging of black.

The ground squirrel is sadly injurious to corn or grain fields, just planted or sown, when the fields are near woods. The squirrel digs up the grain, and renders planting or sowing again necessary.

The gun is the main means for the destruction of the various squirrels.

RATS, MICE, AND THEIR KIND.

WE have hitherto been discussing subjects, presenting rather a doubtful aspect, as affording the possibility of the query arising as to the positive or actual title which they hold to rank amongst the "Pests" of "the Farm." The present article is designed to embrace an inquiry into the character of a class of animals relative to which no possible mistake can exist, - a class of animals whose depredations are universally felt-animals noxious to all, and possessed of no single redeeming quality which can elicit the defence of any one advocate. As to extermination meaning extirpation, that is an end that, even with the greatest assiduity on the part of man, it would be next to hopeless to expect to arrive at; none will question 
the right which man, as the heaven-appointed lord of the creation, possesses to protect his property from the inroads of the invaders, and to check, by every means within his power, the extension of any race of animals, who, if they are to live, must live to his detriment, upon the fruit of his labor. Of all four-footed vermin, perhaps, rats and mice, with their varieties, are the greatest foes to the agriculturist, nay, to man generally. It is, in short, but a choice between their extermination and his; for if suffered to increase in numbers, unchecked, the time would not be far distant when the entire globe would but suffice to furnish food for their rapacious appetites, to the exclusion of the human race, created by our Divine Maker himself its legitimate sovereign and lord. Sentimental theorists need not fear the extinction of this troublesome tribe; let us proceed with all our vigor-let us call into exercise every resource of human cunning, and we shall still find ourselves, to a great extent, baffled by these diminutive marauders, who, despite of all our efforts, continue to thrive, to multiply, to grow fat upon the products of our toil. The utmost that we can effect is to decimate their ranks; we may diminish their numbers, but extirpate them-never! I am far from blaming the poor creatures for their predatory habits. I am fully aware, that in following them, they do but follow certain instincts implanted for wise purposes in their natures, and which, when the earth was yet scantily peopled, and artificial culture comparatively unknown, must have conduced greatly to utility. So it was at creation-so it has been. But many tribes of animals were then created by the Almighty with a view to so many special purposes. According as man advances in knowledge and consequent improvement, so does the necessity for the intervention of brutal aid decrease, until at length what was at first a blessing, will if suffered to remain, become a pest. So it was with the Rat. In earlier ages, when man had no settled habitation, but roved to and fro upon the earth, killing, eating, and wasting, the aid of such animals, as scavengers, was most necessary, in order to maintain the atmosphere in such a pure and healthful condition as was necessary for his support. As cultivation of the soil commenced and progressed, and as the nomadic habits to which I allude ceased, so did the necessity cease for these animals to exist in their wonted numbers. We may, therefore, legitimately conclude, I think, that when it becomes, as it has become, a positive battle between the rats and man for the produce of the ground, and when that produce owes its existence to the labor of the latter, that 
he possesses every legitimate right to exterminate, if he can, his vermin foes, root and branch, and to cry, with the clearest of consciences, "War-war to the-" trap!

There are three descriptions of Rat generally known as a nuisance to the farmer or merchant: the common Brown or Norway Rat, the indigenous Black Rat, and the Water Rat. The last mentioned is seldom a true rat; for what is usually known as Water Rat is not a rat at all, but an animal of an allied genus, properly to be called Vole. The common Brown Rat sometimes also presents $A l$ bino characters, that is to say, it is occasionally to be found of a white color, with red eyes. It is not my intention, neither would it suit the purpose of the present work, to enter at any length into the natural history of these animals; a brief description will therefore suffice.

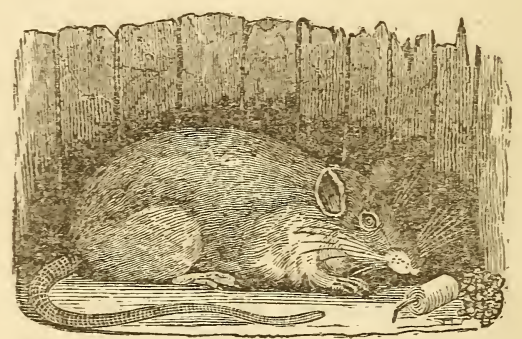

THE COMMON BROWN RAT.

The most formidable is the common Brown Rat (mus decumanus), an animal for whose importation we are indebted to the Norwegians, and which has now almost wholly extirpated our indigenous rariety, the Black Rat (mus rattus). These animals require no description;- - very little to our satisfaction, we are too well acquainted with their appearance. The Black Rat is smaller than the now common variety ; its color is a slaty blue, sometimes a jet black, and its tail is longer and more scaly than that of its Norwegian conqueror. The White Rat is rare, and is merely an accidental variety of the Brown. These animals are all equally mischierous, and resemble each other in their habits, so that the same mode of destruction will answer for all. Various plans for the destruction of rats have been suggested, but I confess that I am not a little surprised that the adoption of some effectual means should be so little general as it is; for I am prepared to assert that were all who 
suffer from the ravages of these pests to apply themselves energetically to the task of getting rid of them, they would-not, certainly, be wholly exterminated, but would become so reduced in numbers as to be no longer formidable-cease, in short, to occupy a position among the "Pests of the Farm."

There are two methods by which rats can be effectually destroyed -TRAPS and POISON. Some writers have recommended the former; others have been in favor of the latter. My own experience induces me to state, that neither is to be adopted to the exclusion of the other, both being equally good under certain circumstances; it must, however, be admitted, that trapping is only suited to instances where the vermin are few in number; where they swarm, wholesale measures must be resorted to, and the trapping of individuals would be idle and useless. When traps are to be employed a small steel spring-trap, similar to that which I have described when treating of the wild cat, \&c., but of course much smaller, is that to be preferred. It must be washed after each capture, and the person who sets it should disguise the natural odor

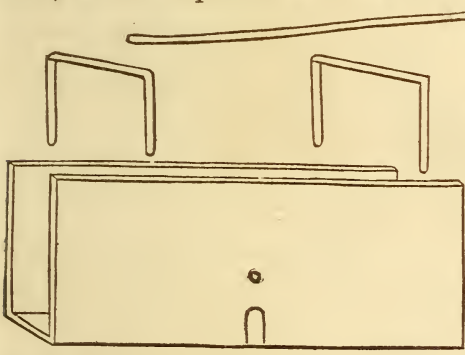
of his person, by using a little malt, impregnated slightly with a mixture of equal parts of the oils of rhodium and caraway. The proportions are 1 part of the mixed oils to 5,000 parts of malt. A portion of this should be rubbed between the hands at each manipulation; this is one of the great secrets of professional rat-catchers. The above is one of the most attractive baits for rats that can be used, and may
be either employed in baiting
traps, or in acting as a vehicle for
using poison. There is another
very good description of trap,
already described, open at both
ends, the doors closing on the
rats running upon a bridge in the
middle. We have endearored
to explain the construction of this 


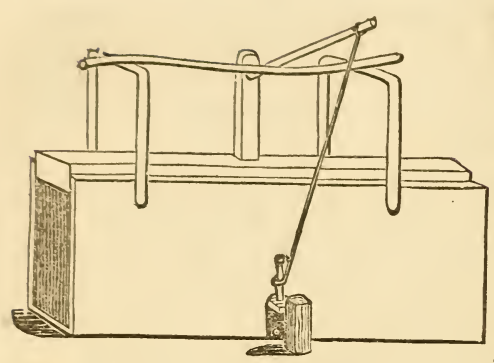

which represent the parts of the trap in a detached statethe third as it appears when set.

There is also a very simple description of trap, which any rustic can make, and which, in the absence of better, may be used with effect: it consists of a long box, open at one end, having the sides grooved. to admit a sliding: door. The better to enable the reader to understand the construction of this trap, we subjoin the accompanying wood-cut:

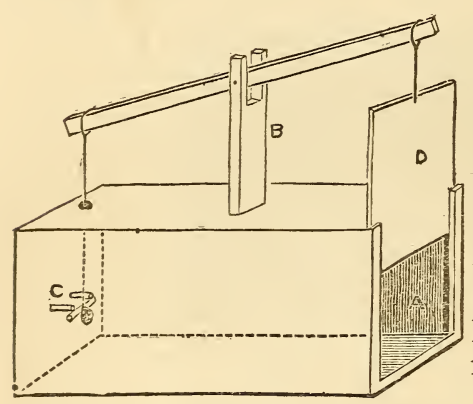

A-Represents the entrance.

B-An upright, supporting a horizontal beam, attached at $\mathrm{C}$ to a string fastened to a bit of meat, which, passing between the two wires represented in the wood-cut, is thus held in that position.

D-Is the door, formed of heary material, and running freely in grooves.

When the horizontal beam is drawn downwards, the bit of meat placed between the wires at $\mathrm{C}$, the door $\mathrm{D}$ rises, and the trap is set. The rat, entering at $\mathrm{D}$, bites the meat at $\mathrm{C}$; the weight of the door, no longer restrained, brings it suddenly down, and the animal is trapped. There cannot be a better trap than this, when the nuisance is confined to a few solitary rats; but, as it only catches one at a time, it is comparatively useless where these pests exist in any number : the fact is, that poison is then the only method to be relied on. There are many objections to the use of poison; amongst others, the obvious one of the danger of poultry, dogs, or other animals, eating the fatal mess, and falling victims to their error. To obviate this and other objections, I shall show how the desired end can be attained by means of a substance fatal to the rats alone-the basis of that substance is phosphorus.

"The following recipe for the destruction of rats has been com- 
municated by Dr. Ure to the Council of the English Agricultural Society, and is highly recommended as the best known means of getting rid of these most obnoxious and destructive vermin. It has been tried by several intelligent persons, and found perfectly effectual. Melt hog's lard in a bottle plunged in water, heated to about 150 degrees of Fahrenheit; introduce into it half an ounce of phosphorus for every pound of lard; then add a pint of proofspirit or whiskey; cork the bottle firmly after its contents hare been heated to 150 degrees, taking it at the same time out of the water, and agitate smartly till the phosphorus becomes uniformly diffused, forming a milky-looking liquid. This liquid, being cooled, will afford a white compound of phosphorus and lard, from which the spirit spontaneously separates, and may be poured off to be used again, for none of it enters into the combination, but it merely serves to comminute the phosphorus, and diffuse it in very fine particles through the lard. This compound, on being warmed very gently, may be poured out into a mixture of wheat flour and sugar incorporated therewith, and then flavored with oil of rhodium, or not, at pleasure. The flavor may be varied with oil of aniseed, \&c. This dough, being made into pellets, is to be laid in ratholes. By its luminousness in the dark, it attracts their notice, and being agreeable to their palates and noses, it is readily eaten, and prores certainly fatal. They soon are seen issuing from their lurking-places to seek for water to quench their burning thirst and bowels, and they commonly die near the water. They continue to eat it as long as it is offered to them, without being deterred by the fate of their fellows, as is known to be the case with arsenical doses. It may be an easy guide for those who are desirous of following Dr. Ure's prescription, and may not hare a thermometer at hand to know that a temperature of 150 degrees of Fahrenheit is equiralent to a degree of heat midway between that at which white of egg coagulates, and white wax melts."

I have little to offer in addition, except to suggest that the vehicle with which the compound of lard and phosphorus is to be used may be fresh malt, instead of a mixture of sugar and wheaten flour; and I would also suggest the following preparation to be added, as an allurement, to induce the rats to eat freely :

$\begin{array}{lllrl}\text { Oil of Rhodium } & \ldots & \ldots & 1 \text { scruple. } \\ \text { Oil of Caraway } & \ldots & \ldots & 1 \text { drachm. } \\ \text { Oil Lavender } & . & \ldots & 5 \text { drops. } \\ \text { Oil of Aniseed } & . & \ldots & 10 \text { drops. } \\ \text { Tincture of Mrusk } & \ldots & & 2 & 2 \text { drops. }\end{array}$


This is to be added to the compost, in the proportion of about 10 drops to the ounce. If kept in a well-stopped bottle, and a bit of bladder tied over the stopper, it will retain its strength for a length of time. The compound of phosphorus and lard was known to professional rat-catchers before Dr. Ure communicated the above formula to the Agricultural Society. A few applications will effect the clearance of the entire premises, and the object then to be desired is to prevent their return. In the "Farmer's Magazine," vol. viii., p. 452, the following receipt is given for this important purpose :- "Take one pound of nitre, and one pound of alum; dissolve them together in two quarts of spring water; get about a bushel of bran, and make a mash thereof, putting in two pints of the above liquid, and mixing all together. When you build your stacks, everr second course, take a handful or two of the mash, and throw upon them till they come to the easing. I have never seen this tried, but an agricultural friend states he has tried it, and found it so successful that he never has a stack put up in any other manner.

Rats may be destroyed in great numbers in a barn, in the following manner :-Before all the grain is remored, get some common iron chafing-dishes, which fill with lighted charcoal, upon this strew a quantity of broken stick brimstone, quit the barn as rapidly as possible, holding rour breath the while, close fast the door, and leave the building shut for the next two dars. On re-entering the barn, you will then find quantities of rats lying dead round the chafing-dishes. Some may have been stifled in their holes, and their bodies might, if no precautions were taken to prevent it, create for some time an unpleasant smell; to prevent this, you have only to stop up all the holes with mortar. Perform this operation again the following harrest, just previous to storing, and you will no longer have any reason to complain of annoyance from the rats. As to the grain in stacks, it will be impossible for rats to injure them, if they be built upon proper staddles or platforms of strne or iron-the former should be built with an orerhanging ledge, which will prevent rermin from ascending-this is unnecessary in the case of the latter, the iron legs presenting a sufficient ol stacle to their ascent.

The water-rat, or more properly, water-ıole, is somewhat larger than the common rat, has a short tail, and small round ears. Tnis animal rarely exists in numbers suffient to do any very great amount of mischief; a ferret and a brace of terriers will, at all 
events, effectually clear a stream of them in a very short time, and the chase will afford exciting amusement of a summer evening.

I shall conclude the subject of the destruction of rats with an amusing account of a novel, but apparently, under the circumstances, a most effective mode of accomplishing this object.

BARRACK FOR RATS.

An extensive bacon-merchant in Limerick, who kills between forty and fifty thousand pigs in a season, has adopted the following successful method to destroy the rats which abound on his premises, where the abundance of food will always occasion a vast collection of these troublesome and destructive animals. $\mathrm{He}$ has erected a quadrangular stone building, eleven feet long, and seven feet wide, with a wall three feet high, having flags laid flat upon the top, but projecting a little over the inside of the wall. All round the wall inside, at the base, are numerous holes, like pigeon holes, which do not go quite through, except a few to allow a free passage to the little animals. Outside of the barrack is a plentiful supply of water and food, such as bones and useless offal. The interior of the walls is occupied by boards, lumber, and strawjust such concealment as these animals are known to prefer, and the whole is covered by a moveable wooden roof. When it is judged proper to destroy them, the passages are stopped at the outside, the roof is lifted off, and the boards are taken out. The frightened animals run up the wall, but their escape is impossible, for they strike against the projecting flags and fall back again. They then run into the small holes below, but these are only just large enough to admit their bodies, whilst the tails remain sticking out, a secure prize to the men who go in orer the wall; and by this unlucky appendage they suddenly drag them out, and fling them to a posse of anxious dogs outside of the fortress, or into a barrel of water, where they are soon destroyed. As there are not holes enough in the wall inside, the noise and uproar soon frighten another division of rats into the racated opening's, and these being treated in the same unceremonious manner, the whole garrison is thus speedily destroyed. As many as seven or eight hundred have been killed in one clearing: Rats being fond of straw, they also become very numerous on the lofts where this article is kept, to be used for singing bacon, and they cut it into short pieces with their teeth, which renders it useless for this purpose. The pro- 
prietor tried the effect of putting a pet fox to mount guard on the lofts, and it was found that he killed such quantities of the rats, that three or four were procured to garrison the place instead of one.

Mrce.-Of this tribe there are several varieties, which some re-

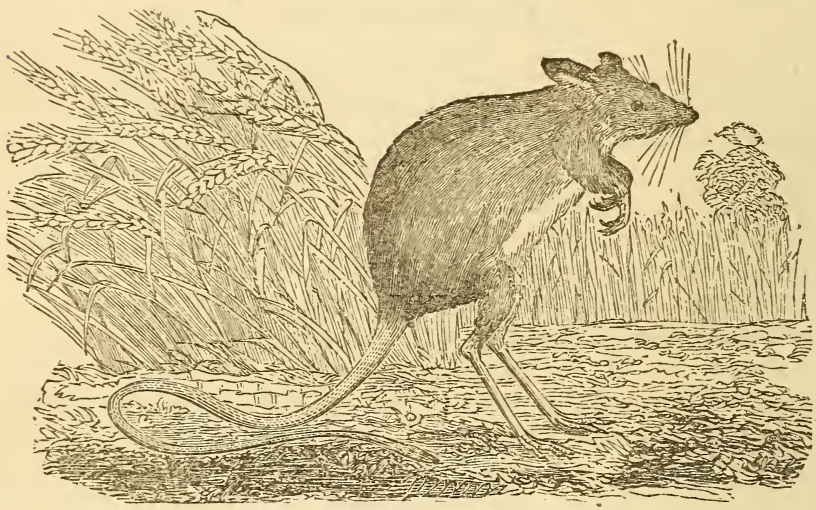

THE JUMPING FIELD MOUSE.

gard as distinct species, while others assert the contrary. I have neither space nor inclination to enter into controversy, and shall confine myself to facts. The common house-mouse, with which all are familiar, is the enemy most to be dreaded in-doors, in the barn, and in the corn-stack. Wherever there are rats, mice will be few in number, the former preying upon the latter. In the field the farmer has both the house-mouse, and two descriptions of fieldmice, or voles (arvicola) to contend with, a long and a short-tailed. These are the principal, and include several sub-varieties. All holes in a dwelling-house should be stopped with lime and pounded glass. The fumigating system will exterminate them from the barn, and if the stacks be built as I have directed, the corn there is safe from their attacks. It is in the field that the battle has to be fought-it is there that mice are really formidable, and require ingenuity to baffle and destroy them. Poison sown in the drills will, of course, destroy mice, but poultry and birds will possibly suffer with them. Our great object, therefore, must be to discover some substance fatal to them, and innoxious to larger animals. 
The small size, and delicate constitution of the mouse, renders this no very difficult matter; and if every farmer will follow my advice, his fields will be soon free. In the first instance, lest farmers should suppose that I exaggerate the havoc which these animals perpetrate, much of it possibly without the knowledge of the proprietor of the soil, who vainly speculates mentally in conjectures as to the cause of his grain-crop having proved so light, I shall present them with the following statement, on the authority of $\mathrm{Mr}$. Maxwell, author of "Wild Sports of the West," who, if I mistake not, quotes from Mr. Jesse.- "An extraordinary instance of the rapid increase of mice, and of the injury they sometimes do, occurred a few years ago in the new plantations made, by order of the crown, in Dean Forest, Gloucestershire, and in the New Forest, Hampshire. Soon after the formation of these plantations, a sudden and rapid increase of mice took place in them, which threatened destruction to the whole of the young plants. Vast numbers of these were killed-the mice having eaten through the roots of five-year old oaks and chesnuts, generally just below the surface of the ground. Hollies, also, which were five and six feet high, were barked round the bottom; and in some instances the mice had crawled up the tree, and were seen feeding on the bark of the upper branches.

"The following account will show the numbers of mice caught in the different enclosures in Dean Forest, in three months, from September to January, with the number of acres, and the proportion between the long and the short-tailed mice:-

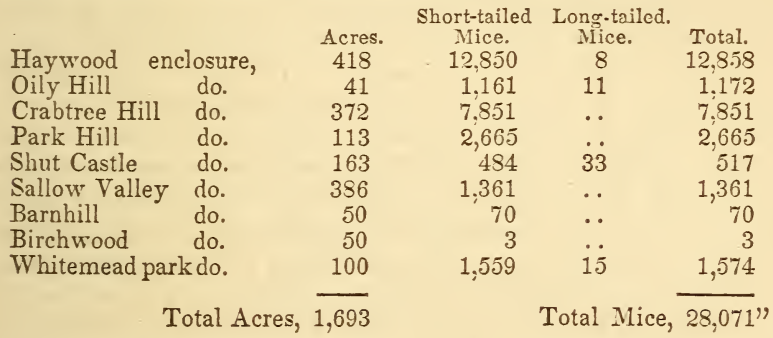

Having now satisfied you of the reality of this nuisance, let us consider some of the modes in which it mav be rernoved.

In "British Husbandry," vol. ii., p. 552 , it is stated that the tops of last year's shoots of furze, chopped small, and sown with the $3^{*}$ 
corn, will prevent their depredations; and it is added, in a note, that their ravages had run to such a height, in some parts of France, as to have mined the farmers! The mode adopted in that country for their destruction is also given :- "At Angerville, whole farms have been giren up to the proprietors, in consequence of their continued devastation; and the only method known of checking them is to defer the sowing any grain until spring, which precaution occasions them to forsake the fields, as it deprives them of the means of winter subsistence." The method adopted in the Forest of Dean, the ravages committed in which we have described above, and which proved efficacious to the fullest extent, after all others had failed, consisted in boring holes in the ground, to the depth of twenty inches, wider at the bottom than at top, in which was dropped some favorite food. The mice willingly entered, and from the form of the hole, being prevented from getting out again, were taken in such numbers as speedily rid the ground of them. One of the best pieces of advice on this subject is the following:"Let the farmer first consider the nature and quality of his ground, and which fields are, from the nature of their soil, most likely to harbor the intruders, also in what places they are most mischievous. Let him never sow these under furrow, $i$. e., until the intruders have been expelled; for that method of cropping deprives him of the power of combating his enemies. They work under ground, as it were, and will never come in the way of his poison. When these fields have been sown otherwise, and harrowed orer, the mice must come upon the surface, and dig down for the corn, and they will then certainly meet with anything he lays on the ground for them." So far, so good. The author proceeds to point out the description of poison to be employed. This is, " a peck of barley meal, a pound of powder of white hellebore root, and four ounces of powder of staves-acre, and when these are all mixed together by sifting through a coarse hair-sieve, add half a pound of honey, and as much milk as will work the whole into a paste. Let this be broken in pieces, and scattered over the field at the time when the mice are known to be coming. They will eat it greedily, and it is certain death to them. There is nothing in any of the ingredients disagreeable to the taste when thus mixed; and every morsel of it will be devoured. The mice will be kept from digging after the corn, and, at the same time, will be killed by the ingredients." I have heard farmers who had tried the above, speak favorably of it. But the most successful remedy of which I have 
yet heard is dropping into the holes, and on different portions of the field, pellets of the phosphoric compound described when treating of the rat. A little trouble of this kind, taken in the heat of summer, when the holes can most easily be seen, will soon greatly diminish the number of the mice, if not wholly extirpate them.

Before leaving this section, I conceive it advisable to say a few words of two valuable aids in the destruction of many of the pests which I have enumerated. I think that a few words of advice as to dogs and ferrets may not be amiss; for, after all, the worst of these four-footed plagues is undeniably the rat. There are three distinct sorts of terrier-the common Scotch, the Skye, and the English. The Scotch is a strong, wire-haired dog, standing moderately high on his legs, with a thick head and a broad muzzle; the Skye is very short on the legs, long in the back, small head, and narrow-muzzled; his hair is also stiff and coarse; the English terrier is short, close-haired, stands high on his legs, has a thickish head, with a long and fine muzzle, and is usually of a black-andtan color. It is not, perhaps, very material as to which of these breeds you have, provided you train them properly to their game.

The proper time for breaking your whelps is at the age of six to eight months; if you do it earlier you may blink or cow them, and if you neglect it to a later period, you may find them unfit, too old for tuition. One great point is to teach your dogs never to mouth-this would prevent them from being rapid killers, and would cause the escape of many a rat: teach them to kill a rat in a single chop, and then to drop the carcase. You will readily effect this by putting him into a corn bin with a dozen or two rats; he will then be in a hurry to get at all, and will not waste his time with any individual.

Ferrets are originally natives of Africa; it will, therefore, be obvious that they require warmth and a perfectly dry hutch. These animals are by no means to be trifled with, as they are only half reclaimed. Goldsmith says they have been known to attack and kill children in the cradle. Mr. Jesse relates an incident that occurred a few years since at Kingston in Surrey, of a ferret attacking a child, and having it nearly killed before it could be removed, and even then perserered in its attacks until its back was broken by repeated kicks, and it perished. I myself was one evening looking for a bitch ferret which I missed from her hutch; it was dark, and I had only a candle to aid me in my search, when she 
suddenly sprang at my face, as I was stooping over her place of concealment-the gloom had prevented my seeing her-and seized me by the cartilage of the nose, to which she hung with all the obstinacy of a bull-dog. I succeeded in getting her off by plunging my face into a tub of water.

When ratting, some ferrets require muzzling, as otherwise they will, if they capture a rat, lie upon the carcase, and, after satiating themselves with the blood, fall asleep there; if they do so, you may get them out by means of smoke, but the use of the muzzle is better. This consists of a little round bit of leather, having a hole in the centre, through which the ferret's nose is passed, and attached with side straps to a collar which encircles the neck. Be careful that there be no loose straps or strings about it, as these might become entangled with roots, \&c., in the hole, and thus keep the ferret prisoner till starved to death.

\section{SECTION II.}

\section{PREDACIOUS BIRDS. \\ EAGLES-KITES AND HAWKS-CROWS, RAVENS, ETC.}

OF all birds, it may be said with truth, that they do more good than harm. Did farmers observe their habits closely, they would know this. Even the crow, detested and destructive as he is, is destructive only for a very few days in each year, and his depredations, in a perceptible manner, are ordinarily confined to the cornfield, just at the season of the sprouting of the seed, and the appearance of the blade above the ground. He somewhat infests newly-sown wheat, oats, and barley. And here ends his depredations. The benefit that his race confers is the destruction of myriads of destroying worms. Did the crow not eat these, they would do far more injury than he does. They cannot be deterred from destroying-he may.. The robin and the woodpecker are pests among the cherries, when ripe, and yet they consume insects, worms, caterpillars, in vast numbers, that living, would destroy far more fruit than the birds. Indeed, it may be said that without birds, we should never grow any fruit. The owl and the hawk, that destroy occasionally a chicken, are mousers, and in the destruction of mice and molss, repay amply the evil they do. 
It may reasonably be doubted if any birds, even the eagle, does as much harm as good. We always observe the evil done, rarely the benefit rendered.

Among the birds, the only pests worthy of being noticed are the eagle, the crow and raven, the hawk (or kite, as he is frequently called), and the owl.

The Eagle.-The eagle is a formidable "pest of the farm," pouncing from time to time upon the various inmates of the poultry-yard, and carrying away the young in its talons, and even occasionally extending its depredations to a young pig or lamb; besides, being, in some instances, known to attack a sickly or dying beast, and to anticipate death by (vulture fashion) pecking out its eyes. Still it must be admitted that the eagle usually behaves in a nobler manner, and, unless when very hard pinched by appetite, contents himself with such prey as he can convey away to his nest, or, as it is called, his eyrie, on the distant cliff.

There are three sorts of eagle whose depredations are most to be feared by farmers: These are, the Bald Eagle or White-Headed Eagle, the Ring-Tailed Eagle, and the Sea Eagle. A few words relative to the destruction of these birds will suffice, and the one set of directions will equally apply to all. The best mode of protection against the ravages of the eagles is to shoot them where seen, and to have their nests annually robbed. This is best managed by offering a bounty for the capture of young ones, or, as they are called, the eaglets.

Bald Eagle or White-Headed Eagle.-This distinguished bird is entitled to particular notice. He has been long known to naturalists, being common to both continents, and occasionally met with from a very high northern latitude, to the borders of the torrid zone, but chiefly in the vicinity of the sea, and along the shores and cliffs of our lakes and large rivers. Formed by nature for braving the severest cold; feeding equally on the produce of the sea and of the land; possessing powers of flight capable of outstripping even the tempests themselves; unawed by anything but man; and, from the ethereal heights to which he soars, looking abroad, at one glance, on an immeasurable expanse of forests, fields, lakes, and ocean, deep below lim, he appears indifferent to the little localities of change of seasons; as, in a few minutes, he can pass from summer to winter, from the lower to the higher regions of the atmosphere, the abode of eternal cold, and thence de- 
scend, at will, to the torrid, or the arctic regions of the earth. $\mathrm{He}$ is, therefore, found, at all seasons, in the countries he inhabits; but prefers such places as have been mentioned above, from the great partiality he has for fish.

In procuring these, he displays, in a very singular manner, the genius and energy of his character, which is fierce, contemplative, daring, and ty rannical,-attributes not exerted but on particular occasions, but, when put forth, overpowering all opposition.

When driven, as he sometimes is, by the combined courage and persererance of the fish hawks, from their neighborhood, and forced to hunt for himself, he retires more inland, in search of young pigs, of which he destroys great numbers. In the lower parts of Virginia and North Carolina, where the inhabitants raise vast herds of those animals, complaints of this kind are very general against him. He also destroys young lambs in the early part of spring; and will sometimes attack old sickly sheep, aiming furiously at their eyes.

His intrepidity of character may be illustrated by the following fact, which occurred a few years ago, near Great Egg Harbor, New Jersey :-A woman, who happened to be weeding in the garden, had set her child down near, to amuse itself while she was at work; when a sudden and extraordinary rushing sound, and a scream from her child, alarmed her, and, starting up, she beheld the infant thrown down, and dragged some few feet, and a large bald eagle bearing off a fragment of its frock, which being the only part seized, and giving way, providentially saved the life of the infant.

The appetite of the bald eagle, though habituated to long fasting, is of the most voracious, and often the most indelicate kind. Fish, when he can obtain them, are preferred to all other fare. Young lambs and pigs are dainty morsels, and made free with on all favorable occasions. Ducks, geese, gulls, and other sea fowl, are also seized with avidity.

The white-headed eagle is three feet long, and seven feet in extent; the bill is of a rich yellow; cere, the same, slightly tinged with green ; mouth, flesh-colored; tip of the tongue, bluish black; the head, chief part of the neck, vent, tail-coverts, and tail, are white in the perfect, or old birds of both sexes, -in those under three years of age these parts are of a gray brown; the rest of the plumage is dark brown, each feather tipped with pale brown, lightest on the shoulder of the wing, and darkest towards its extremities. The conformation of the wing is admirably adapted 
for the support of so large a bird ; it measures two feet in breadth on the greater quills, and sixteen inches on the lesser; the longest primaries are twenty inches in length, and upwards of one inch in circumference where they enter the skin; the broadest secondaries are three inches in breadth across the vane; the scapulars are very large and broad, spreading from the back to the wing, to prevent the air from passing through; another range of broad flat feathers, from three to ten inches in length, also extends from the lower part of the breast to the wing below, for the same purpose; between these lies a deep triangular cavity; the thighs are remarkably thick, strong, and muscular, covered with long feathers pointing backwards, usually called the femoral feathers; the legs, which are covered half way below the knee, before, with dark, brown downy feathers, are of a rich yellow, the color of ripe Indian corn; feet, the same; claws, blue-black, very large and strong, particularly the inner one, which is considerably the largest; soles, very rough and warty ; the eye is sunk under a bony, or cartilaginous projection, of a pale yellow color, and is turned considerably forwards, not standing parallel with the cheeks; the iris is of a bright straw color, pupil black.

The male is generally two or three inches shorter than the female; the white on the head, neck, and tail being more tinged with yellowish, and its whole appearance less formidable; the brown plumage is also lighter, and the bird itself less daring than the female, - a circumstance common to almost all birds of prey.

The eagle is said to live to a great age,-sixty, eighty, and, as some assert, one hundred years. This circumstance is remarkable, when we consider the seeming intemperate habits of the bird, sometimes fasting, through necessity, for several days, and at other times gorging itself with animal food till its craw swells out the plumage of that part, forming a large protuberance on the breast. This, however, is its natural food, and for these habits its whole organization is particularly adapted. Its food is simple, it indulges freely, uses great exercise, breathes the purest air, is healthy, vigorous, and long lived.

The Rivg-Tailed Eagle.-This noble bird, in strength, spirit, and activity, ranks among the first of its tribe. It is found, though sparingly dispersed, over the whole temperate and arctic regions, particularly the latter; breeding on high, precipitous rocks, always preferring a mountainous country.

The ring-tailed eagle measures nearly three feet in length; the 
bill is of a brownish horn color; the cere, sides of the mouth, and feet, yellow ; iris of the eye, reddish hazel, the eye turned considerably forwards; eyebrow, remarkably prominent, projecting over the eye, and giving a peculiar sternness to the aspect of the bird; the crown is that; the plumage of the head, throat, and neck, long and pointed; that on the upper part of the head and neck, very pale lerruginous; fore part of the crown, black; all the pointed feathers are shafted with black; whole upper parts, dark blackish brown; wings, black; tail, rounded, long, of a white, or pale cream color, minutely sprinkled with specks of ash, and dusky, and cnding in a broad band of deep dark brown, of nearly one-third its length; chin, cheeks, and throat, black; whole lower parts, a deep dark brown, except the vent and inside of the thighs, which are white, stained with brown; legs, thickly covered to the feet, with brownish white down, or feathers; claws, black, very large, sharp, and formidable, the hind one full two inches long.

The ring-tailed eagle is found in the northern parts of America.

Sea Eagle or Gray Eagle.-This eagle inhabits the same countries, frequent the same situations, and lives on the same kind of food, as the bald eagle, with whom it is often seen in company. It resembles this last much in figure, size, form of the bill, leg's, and claws, and is often seen associating with it both along the Atlantic coast and in the vicinity of our lakes and large rivers.

The sea eagle is said, by Salerne, to build on the loftiest oaks a very broad nest, into which it drops two large eg's's, that are quite round, exceedingly heavy, and of a dirty white color. Of the precise time of building, we have no account.

The bird measures three feet in length, and upwards of seven feet in extent. The bill formed exactly like that of the bald eagle, but of a dusky brown color; cere and legs, bright yellow ; the latter, as in the bald eagle, feathered a little below the knee; irides, a bright straw color; head above, neck, and back, streaked with light brown, deep brown, and white, the plumage being white, tipped and centred with brown; scapulars, brown; lesser wingcoverts, very pale, intermixed with white; primaries, black, their shafts brownish white; rump, pale brownish white; tail, rounded, somewhat longer than the wings, when shut, brown on the exterior vanes, the inner ones white, sprinkled with dirty brown; throat, breast, and belly, white, dashed and streaked with different tints of brown and pale yellow; vent, brown, tipped with white; femorals, dark brown, tipped with lighter; auriculars, brown, forming a bar 
from below the eye backwards ; plumage of the neck, long, narrow, and pointed, as is usual with eagles, and of a brownish color tipped with white.

The sea eagle is said to hunt at night, as well as during the day, and that, besides fish, it feeds on chickens, birds, hares, and other animals. It is also said to catch fish during the night; and that

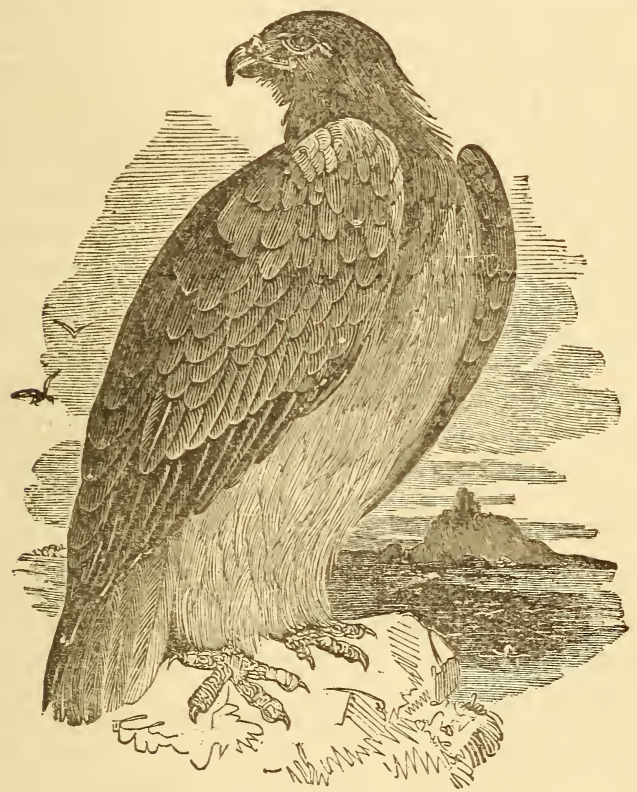

THE SEA EAGLE.

the noisc of its plunging into the water is heard at a great distance. But, in the descriptions of writers, this bird has been so frequently confounded with the osprey, as to leave little doubt that the habits and manners of the one have been often attributed to both, and others added that are common to neither.

The gun, poisoned meats, or traps baited with meat or fish, are the only means of destroying eagles.

The CRow.-This is perhaps the most generally known, and least beloved, of all our land birds ; having neither melody of song, 
nor beauty of plumage, nor excellence of flesh, nor civility of manner's to recommend him; on the contrary, he is branded as a thief and a plunderer-a kind of black-coated vagabond, who hovers over the fields of the industrious, fattening on their labors, and, by his voracity, often blasting their expectations. Hated as he is by the farmer, watched and persecuted by almost every bearer of a gun, who all triumph in his destruction, had not Heaven bestowed on him intelligence and sagacity far beyond common, there is reason to believe that the whole tribe (in these parts at least) would long ago have ceased to exist.

The crow is a constant attendant on agriculture, and a general inhabitant of the cultivated parts of North America. In the interior of the forest he is more rare, unless during the season of breeding. He is particularly attached to low flat corn countries, lying in the neighborhood of the sea, or of large rivers ; and more numerous in the northern than southern states. A strong antipathy, it is said, prevails between the crow and the raven, insomuch, that where the latter is numerous, the former rarely resides.

The usual breeding time of the crow, is in March, April, and May, during which season they are dispersed over the woods in pairs, and roost in the neighborhood of the tree they have selected for their nest. About the middle of March they begin to build, generally choosing a high tree.

It is in the month of May, and until the middle of June. that the crow is most destructive to the corn-fields, digging up the newly planted grains of maize, pulling up by the roots those that have begun to vegetate, and thus frequently obliging the farmer to replant, or lose the benefit of the scil; and this sometimes twice, and even three times, occasioning a considerable additional expense, and inequality of harvest. No mercy is now shown him. The myriads of worms, moles, mice, caterpillars, grubs, and beetles, which he has destroyed, are altogether overlooked on these occasions. Detected in robbing the hens' nests, pulling up the corn, and killing the young chickens, he is considered as an outlaw, and sentenced to destruction. But the great difficulty is, how to put this sentence in execution. In vain the gunner skulks along the hedges and fences; his faithful sentinels, planted on some commanding point, raise the alarm, and disappoint vengeance of its object. The coast again clear, he returns once more in silence, to finish the repast he had begun. Sometimes he approaches the farm-house by stealth, in search of young chickens, which he is in 
the habit of snatching off, when he can elude the vigilance of the mother hen, who often proves too formidable for him.

The crow himself sometimes falls a prey to the superior strength and rapacity of the great owl, whose weapons of offence are by far the more formidable of the two.

Towards the close of summer, the parent crows, with their new families, forsaking their solitary lodgings, collect together, as if by previous agreement, when evening approaches. About an hour before sunset, they are first observed, flying, somewhat in Indian file, in one direction, at a short height above the tops of the trees, silent and steady, keeping the general curvature of the ground, continuing to pass sometimes till after sunset, so that the whole line of march would extend for many miles. This circumstance, so familiar and picturesque, has not been overlooked by the poets, in their descriptions of a rural evening.

Crows form large roosts and dwell in them in immense numbers. A large one appears to be the grand rendezvous, or head-quarters, of the greater part of the crows within forty or fifty miles of the spot. The noise created by these multitudes, both in their evening assembly and reascension in the morning, and the depredations they commit in the immediate neighborhood of a great resort, are almost incredible. Whole fields of corn are sometimes laid waste by thousands alighting on it at once, with appetites whetted by the fast of the preceding night; and the utmost vigilance is unavailing to prevent, at least, a partial destruction of this their favorite grain. Like the stragglers of an immense, undisciplined, and rapacious army, they spread themselves over the fields, to plunder and destroy wherever they alight. It is here that the character of the crow is universally execrated; and to say to the man who has lost his crop of corn by these birds, that crows are exceedingly useful for destroying vermin, would be as consolatory as to tell him who had just lost his house and furniture by the flames, that fires are excellent for destroying bugs.

So universal is the hatred to crows, that few states have neglected to offer rewards for their destruction. In the United States, they have been repeatedly ranked in our laws with the wolves, the panthers, foxes, and squirrels, and a proportionable premium offered for their heads, to be paid by any justice of the peace to whom they are delivered. On all these accounts, various modes have been invented for capturing them. They have been taken in clapnets, commonly used for taking pigeons; two or three live crows 
being previously procured as decoys, or, as they are called, stoolcrows. Corn has been steeped in a strong decoction of hellebore, which, when eaten by them, produces giddiness, and finally, it is said, death. Pieces of paper tormed into the shape of a hollow cone, besmeared within with birdlime, and a grain or two of corn dropped on the bottom, have also been adopted. Numbers of these being placed on the ground, where corn has been planted, the crows attempting to reach the grains, are instantly hoodwinked, fly directly upwards to a great height; but generally descend near the spot whence they rose, and are easily taken. The reeds of their roosting places are sometimes set on fire during a dark night, and the gunners having previously posted themselves around, the crows rise in great uproar, and, amidst the general consternation, by the light of the burnings, hundreds of them are shot down.

Crows have been employed to catch crows, by the following stratagem:-A live crow is pinned by the wings down to the ground on his back, by means of two sharp, forked sticks. Thus situated, his cries are loud and incessant, particularly if any other crows are within view. These, sweeping down about him, are instantly grappled by the prostrate prisoner, by the same instinctive impulse that urges a drowning person to grasp at everything within. his reach. Haring disengaged the game from his clutches, the trap is again ready for another experiment; and by pinning down each captive, successively, as soon as taken, in a short time you will probably have a large flock screaming above you, in concert with the outrageous prisoners below. Many farmers, however, are content with hanging up the skins, or dead carcasses, of crows in their corn-fields, in terrorem; others depend altogether on the gun, keeping one of their people supplied with ammunition, and constantly on the look out.

The habits of the crow in his native state are so generally known as to require little further illustration. His watchfulness, and jealous sagacity in distinguishing a person with a gun, are notorious to every one. In spring, when he makes his appearance among the groves and low thickets, the whole feathered songsters are instantly alarmed, well knowing the depredations and murders he commits on their nests, eggs, and young. Few of them, however, have the courage to attack him, except the king bird, who, on these occasions, teases and pursues him from place to place, diving on his back while high in the air, and harassing him for a great distance. A single pair of these noble-spirited birds, whose nest was built 
near, have been known to protect a whole field of corn from the depredations of the crows, not permitting one to approach it.

The crow is eighteen inches and a halï long, and three feet two inches in extent; the general color is a shining glossy blue black, with purplish reflections; the throat and lower parts are less glossy; the bill and legs, a shining black, the former two inches and a quarter long, very strong, and covered at the base with thick tufts of recumbent feathers; the wings, when shut, reach within an inch and a quarter of the tip of the tail, which is rounded; fourth primary, the longest; secondaries scolloped at the ends, and minutely pointed, by the prolongation of the shaft; iris, dark hazel.

The female differs from the male in being more dull colored, and rather deficient in the glossy and purplish tints and reflections. The difference, however, is not great.

Besides grain, insects, and carrion, they feed on frogs, tadpoles, small fish, lizards, and shell fish; with the latter they frequently mount to a great height, dropping them on the rocks below, and descending after them to pick up the contents. Many other aquatic insects, as well as marine plants, furnish them with food; which accounts for their being so generally found, and so numerous, on the sea shore, and along the banks of our large rivers.

The Ravex.-The raven is a general inhabitant of the United States, but is more common in the interior. It is a remarkable fact, that where they so abound, the common crow seldom makes its appearance; being intimidated, it is conjectured, by the superior size and strength of the former, or by an antipathy which the two species manifest towards each other.

The food of this species is dead animal matter of all kinds, not excepting the most putrid carrion, which it devours in common with the vultures ; worms, grubs, reptiles, and shell fish, the last of which, in the manner of the crow, it drops from a considerable height in the air, on the rocks, in order to break the shells; it is fond of bird's eggs, and is often observed sneaking around the farm-house in search of the eggs of the domestic poultry, which it sucks with eagerness ; it is likewise charged with destroying young ducks and chickens, and lambs which have been yeaned in a sickly state.

The raven measures, from the tip of the bill to the end of the tail, twenty-six inches, and is four feet in extent; the bill is large and strong, of a shining black, notched near the tip, and three in- 
ches long; the setaceous feathers which cover the nostrils extend half its length; the eyes are black; the general color is a deep glossy black, with steel-blue reflections; the lower parts are less glossy ; the tail is rounded, and extends about two inches beyond the wings; the legs are two inches and a half in length, and, with the feet, are strong and black; the claws are long.

This bird is said to attain to a great age; and its plumage to be subject to change from the influence of years and of climate. It is found in Iceland and Greenland entirely white.

The raven may be destroyed in several of the many ways adopted to kill the crow. He is more easily shot than the crow.

OF Hawns there is a great variety in America. Those only are described that are common and diffused enough to be generally troublesome.

American Sparrow Hawk.-This bird is a constant resident in almost every part of the United States, particularly in the states north of Maryland. In the Southern States there is a smaller species found, which is destitute of the black spots on the head; the legs are long and very slender, and the wing's light blue,

The nest of this species is usually built in a hollow tree; generally pretty high up, where the top, or a large limb, has been broken off. The female generally lays four or five eggs, which are of a light brownish yellow color, spotted with a darker tint; the young are fed on grasshoppers, mice, and small birds, the usual food of the parents.

The habits and manners of this bird are well known. It flies rather irregularly, occasionally suspending itself in the air, hovering over a particular spot for a minute or two, and then shooting off in another direction. It perches on the top of a dead tree or pole, in the middle of a field or meadow, and, as it alights, shuts its long wings so suddenly, that they seem instantly to disappear; it sits here in an almost perpendicular position, sometimes for an hour at a time, frequently jerking its tail, and reconnoitring the ground below, in every direction, for mice, lizards, \&c. It approaches the farm-house, particularly in the morning, skulking: about the barn-yard for mice or young chickens. It frequently plunges into a thicket after small birds, as if by random, but always with a particular, and generally a fatal, aim. It is particularly fond of watching along hedge-rows, and in orchards, where those small birds usually resort. When grasshoppers are plenty, they form a considerable part of its food. 
Though small snakes, mice, lizards, \&c., be favorite morsels with this active bird, yet we are not to suppose it altogether destitute of delicacy in feeding. It will seldom or never eat of anything that it has not itself killed, and even that, if not in good eating order, is sometimes rejected.

The female of this species is eleven inches long, and twentythree from tip to tip of the expanded wings. The cere and legs are yellow; bill, blue, tipped with black; space round the eye, greenish blue; iris, deep dusky; head, bluish ash ; crown, rufous ; seven spots of black on a white ground surround the head; whole upper parts reddish bay, transversely streaked with black ; primary and secondary quills, black, spotted on their inner vanes with brownish white; whole lower parts, yellowish white, marked with longitudinal streaks of brown, except the chin, vent, and femoral feathers, which are white; claws, black.

The male sparrow hawk measures about ten inches in length, and twenty-one in extent; the whole upper parts of the head are of a fine slate blue, the shafts of the plumage being black, the crown excepted, which is marked with a spot of bright rufous; the slate tapers to a point on each side of the neck; seven black spots surround the head, as in the female, on a reddish white ground, which also borders each sloping side of the blue; front, lores, line over and under the eye, chin, and throat, white; femoral and ventfeathers, yellowish white; the rest of the lower parts, of the same tint, each feather being streaked down the centre with a long black drop ; those on the breast, slender, on the sides, larger; upper part of the back and scapulars, deep reddish bay, marked with ten or twelve tranverse waves of black; whole wing-coverts and ends of the secondaries, bright slate, spotted with black; primaries and upper half of the secondaries, black, tipped with white, and spotted on their inner vanes with the same; lower part of the back, the rump, and tail-coverts, plain bright bay ; tail rounded, the two exterior feathers white, their inner vanes beautifully spotted with black; the next, bright bay, with a broad band of black near its end, and tipped for half an inch with yellowish white; part of its lower exterior edge, white, spotted with black, and its opposite interior edge, touched with white; the whole of the others are very deep red bay, with a single, broad band of black near the end, and tipped with yellowish white; cere and legs, yellow; orbits, the same; bill, light blue; iris of the eye, dark, almost black; claws, blue-black. 
Red-TAILEd Hawk.-This species inhabits the whole United States, and is not migratory. Among extensive meadows, where flocks of larks, and where mice and moles are in great abundance, many individuals of this hawk spend the greater part of the winter. Others prowl around the plantations, looking out for vagrant chickens; their method of seizing which is, by sweeping swiftly over the spot, and, grappling them with their talons, bearing them away to the woods.

The red-tailed hawk is twenty inches long, and three feet nine inches in extent; bill, blue-black; cere, and sides of the mouth, yellow, tinged with green; lores, and spot on the under eyelid, white, the former marked with fine, radiating hairs; eyebrow, or cartilage, a dull eel-skin color, prominent, projecting over the eye ; a broad streak of dark brown extends from the sides of the mouth backwards ; crown and hind head, dark brown, seamed with white, and ferruginous; sides of the neck, dull ferruginous, streaked with brown; eye, large; iris, pale amber; back and shoulders, deep brown; wings, dusky, barred with blackish; ends of the five first primaries, nearly black; scapulars, barred broadly with white and brown; sides of the tail-coverts, white, barred with ferruginous, middle ones dark, edged with rust; tail, rounded, extending two inches beyond the wings, and of a bright red brown, with a single band of black near the end, and tipped with brownish white; on some of the lateral feathers are slight indications of the remains of other narrow bars; lower parts, brownish white; the breast, ferruginous, streaked with dark brown; rcross the belly, a band of interrupted spots of brown; chin, white; femorals and vent, pale brownish white, the former marked with a few minute heartshaped spots of brown; legs, yellow, feathered half way below the knees.

The gun, or traps baited with mice, toads, \&c., or a dead fowl, are the proper. means to destroy hawks.

Ows.- There is a great variety of owls all orer America. Some are so rare as to be of no account as pests; others are common everywhere. The predacious habits of all are the same. Those that are described will, as far as evil habits are concerned, represent the whole variety.

The BARRed OwL.-This is one of our most common owls. It is very frequently observed flying during day, and certainly sees more distinctly at that time than many of its genus.

These birds sometimes seize on fowls, partridges, and young rab- 
bits; mice and small game are, however, therr most usual food. The difference in size between the male and female of this owl is extraordinary, amounting sometimes to nearly eight inches in the length. Both scream during day, like a hawk.

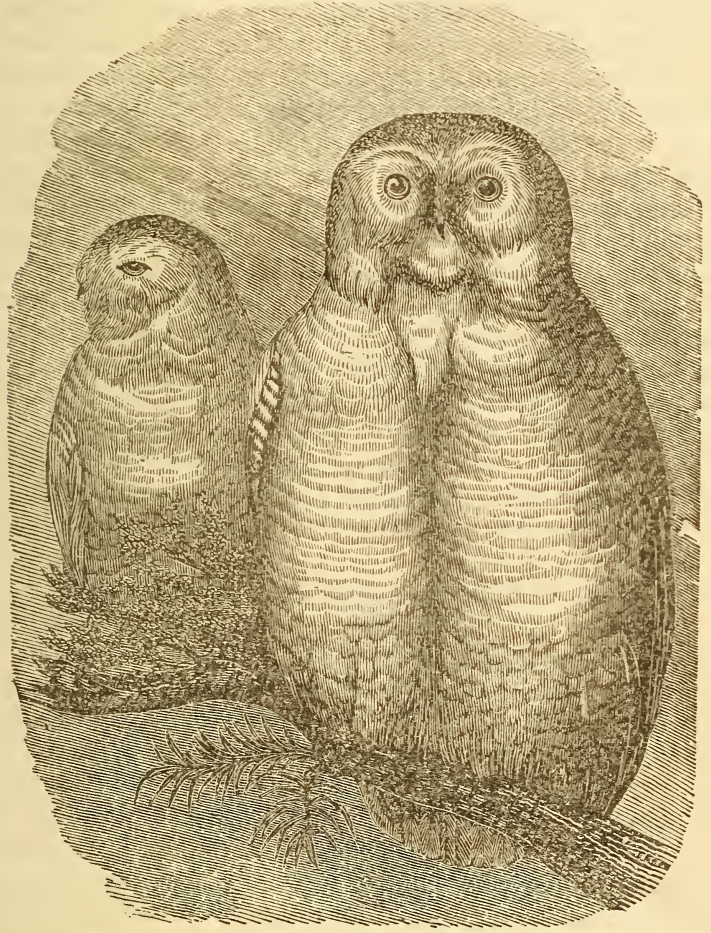

THE OWL.

The male barred owl measures sixteen inches and a half in length, and thirty-eight inches in extent; upper parts a pale brown, marked with transverse spots of white; wings barred with alternate bands of pale brown, and darker; head, smooth, very large, mottled with transverse touches of dark brown, pale brown, and white; eyes, large, deep blue, the pupil not perceivable; face, or radiated circle of the eyes, gray, surrounded by an outline of brown 
and white dots; bill, yellow, tinged with green; breast, barred transversely with rows of brown and white; belly, streaked longitudinally with long stripes of brown, on a yellowish ground; vent, plain yellowish white; thighs and feathered legs, the same, slightly pointed with brown; toes, nearly covered with plumage; claws, dark horn color, very sharp ; tail, rounded, and remarkably concave below, barred with six broad bars of brown, and as many narrow ones of white; the back and shoulders have a cast of chestnut; at each internal angle of the eye, is a broad spot of black; the plumage of the radiated circle round the eye ends in long black hairs; and the bill is encompassed by others of a longer and more bristly kind. These probably serve to guard the eye when any danger approaches it in sweeping hastily through the woods; and those usually found on flycatchers may have the same intention to fulfill ; for, on the slightest touch of the point of any of these hairs, the nicitant membrane was instantly thrown over the eye.

The female is twenty-two inches long, and four feet in extent; the chief difference of color consists in her wings being broadly spotted with white; the shoulder being a plain chocolate brown; the tail extends considerably beyond the tips of the wings ; the bill is much larger, and of a more golden yellow; iris of the eye, the same as that of the male.

Little OwL.-This is one of the least of its whole genus; but, like many other little folks, makes up, in neatness of general form and appearance, for deficiency of size, and is, perhaps, the most shapely of all our owls. Nor are the colors and markings of its plumage inferior in simplicity and effect to most others. It also possesses an eye fully equal in spirit and brilliancy to the best of them.

This species is a general and constant inhabitant of the middle and northern states; but is found most numerous in the neighborhood of the sea-shore, and among woods and swamps of pine trees. It rarely rambles much during day; but, if disturbed, flies a short way, and again takes shelter from the light; at the approach of twilight it is all life and activity, being a noted and dextrous mouse-catcher.

The little owl is seven inches and a half long, and eighteen inches in extent; the upper parts are a plain brown olive, the scapulars and some of the greater and lesser coverts being spotted with white; the first five primaries are crossed obliquely with five bars of white; tail, rounded, rather darker than the body, crossed with 
two rows of white spots, and tipped with white; whole interior vanes of the wings, spotted with the same; auriculars, yellowish brown; crown, upper part of the neck, and circle surrounding the ears, beautifully marked with numerous points of white on an olive brown ground; front, pure white, ending in long blackish hairs; at the internal angle of the eyes, a broad spot of black radiating outwards; irides, pale yellow; bill, a blackish horn color; lower parts, streaked with yellow ochre and reddish bay; thighs, and feathered legs, pale buff; toes, covered to the claws, which are black, large, and sharp-pointed.

RED OWL.-This is another of our nocturnal wanderers, well kuown by its common name, the little screech owl ; and noted for its melancholy quivering kind of wailing in the evenings, particularly towards the latter part of summer and autumn, near the farmhouse. On clear moonlight nights, they answer each other from various parts of the fields or orchards; roost during the day in thick evergreens, such as cedar, pine, or juniper trees, and are rarely seen abroad in sunshine. In May, they construct their nest in the hollow of a tree, often in the orchard in an old apple tree; the nest is composed of some hay and a few feathers; the egg's are four, pure white, and nearly round. The young are at first covered with a whitish down.

This species is found generally over the United States, and is not migratory.

The red owl is eight inches and a half long, and twenty-one inches in extent; general color of the plumage above, a bright nut brown, or tawny red; the shafts, black; exterior edges of the outer row of scapulars, white; bastard wing, the five first primaries, and three or four of the first greater coverts, all spotted with white; whole wing-quills, spotted with dusky on their exterior webs; tail, rounded, transversely barred with dusky and pale brown; chin, breast, and sides, bright reddish brown, streaked laterally with black, intermixed with white; belly and rent, white, spotted with bright brown; leg's, covered to the claws with pale brown hairy down; extremities of the toes and claws, pale bluish, ending in black; bill, a pale bluish horn color; eyes, vivid yellow; inner angles of the eyes, eyebrows, and space surrounding the bill, whitish ; rest of the face, nut brown; head, horned or eared, each horn consisting of nine or ten feathers of a tawny red, shafted with black.

Great Horned OwL-This noted and formidable owl is found 
in almost every quarter of the United States. His favorite residence, however, is in the dark solitudes of deep swamps, covered with a growth of gigantic timber; and here, as soon as evening draws on, and mankind retire to rest, he sends forth such sounds as seem scarcely to belong to this world, startling the solitary pilgrim as he slumbers by his forest fire, "making night hideous."

It preys on young rabbits, squirrels, rats, mice, partridges, and small birds of various kinds. It has been often known to prowl about the farm-house, and carry off chickens from roost.

The owl being nocturnal, is not easily shot, but may be occasionally. He may be taken in traps baited with mice, fowls, or any of his usual food.

\section{SECTION III.}

INSECTS.

It is in the larva state that the ravages of insects are most felt, and this requires a word or two of explanation.

Butterflies, Moths, and many other insects, undergo a succession of changes, or transformations, prior to their assuming their last and frequently gorgeous form, under which we see them fluttering from flower to flower. Of course, I speak now more particularly of the butterfly. The moths are usually, though, no doubt, many of them are extremely beautiful, much more sober in their movements, and less gaudy in their plumage. They are, also, principally of nocturnal habits, and consequently come less frequently, and less strikingly, under our notice.

The female moth or butterfly deposits an egg, which, gradually ripening to maturity, becomes, a maggot, grub, or caterpillar. This is called the larva, and it is in this stage that the insects prove most noxious to the farmer's crops. These larvæ are excessively voracious, and their ravages terminate only with their next transformation into the state of pupa, or chrysalis. Prior to assuming this state, the caterpillar forsakes its food, and seeks some retired and safe retreat, usually burying itself for this purpose underground. The head then gradually bends forward, and the face is embraced by the upper or thoracic feet; the body likewise becomes contracted in its dimensions, more particularly in its length, and 
also gradually becomes covered with a firm and shell-like coat or case. This is a thickening and induration of the skin of the grub, not of the epidermis or cuticle; for that is gradually cast as a slough, in proportion as the work of transformation proceeds. The chrysalis is soon formed; some insects envelop themselves in a web, as the silkworm, \&c. ; others do not. During this stage, the insect is, of course, perfectly harmless. In course of time, the perfect insect is formed within its shelly sheath; it now commences the work of breaking open its prison, having effected which, it emerges in all the beauty of insect perfection.

Caterpillars do not prey indiscriminately on all sorts of herbage or farming produce. Each species has its favorite plant, or plants; and not even starvation will induce it to transgress these limits that instinct has assigned to its appetite, or eat of a plant of another sort.

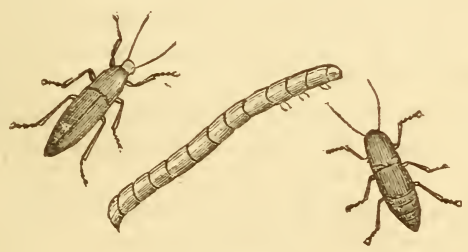

THE WIREWORM, AND PARENT BEETLES, MALE AND FEMALE.

One of the most destructive grubs which infests the fields of the agrieulturist, or renders futile the care and skill of the gardener, is, perhaps, that well-known larva-the Wireworm. I may here observe that the general name of wireworm is given to the larva of many species of beetle, all, however, very similar in habits and appearance, and so equally gifted as to their destructive powers, that it would be difficult, indeed, to draw any distinction in this respect between them.

Scarcely any land is free from the ravages of some one or other of the wireworms; and there is scarcely any description of crop upon which they will not prey with equal greediness. Wherever grass or any sort of herbage will grow, there will the greedy wireworm be found. The beetles, of which the wireworms are the larvæ, are those called the Elaters; also spring-beetles, skip- 
jacks, and click or snip-beetles, from the power they possess of springing up with a click or snap-like noise when placed upon their backs: The eggs of the wireworm are very minute, and are deposited in the earth at the root of the young plants. When first hatched they are invisible to the naked eye, but attain nearly the length of an inch when full grown, and in this state of larvæ they remain for nearly five years. No wonder, therefore, that, between their longevity and rapacity, they should be deemed by farmers so very pestilent a scourge. During the continuance of their larva state, these worms cast their outer skin several times, being white in color, and very tender for a short period after each sloughing; at other times they are covered with a hard and solid coat of a horny consistence, so firm and impenetrable as to render them proof against most of the ordinary remedies that might be used for their destruction.

Wireworms are somewhat more than half an inch in length, and resemble the meal-worm in appearance, but are more angular, less perfectly cylindrical, more flattened above and below. Their head is horny and formed for perforation, and the mouth, though small, is furnished with a most effective pair of very powerful jaws. There are six feet on the upper portion of the thorax, and one at the extremity or tail. The former are called pectoral or thoracic, the latter anal.

When full-grown, the wireworm buries itself in the ground, where it forms a cell, in which it becomes a chrysalis or pupa; this change takes place early in autumn, and in two or three weeks at farthest it becomes a beetle. The beetles are harmless, feeding only on flowers; they can fly well, and when on the ground can run very fast, with their heads down, and drop when approached. The mouth is not the same in appearance with that which existed in the worm, but will, on examination, be found to be formed of the same organs, only perfected.

There are two species of beetle that produce the wireworm, more common in grain-fields than the rest, and therefore the more to be dreaded. These are : the elater appressifrons, and the elater obesus.

The bug parent is familiarly known as the snapping bug. As before said the worm continues five years before its transmutation to the perfect insect state, during which time it feeds on the roots of wheat, barley, oats, corn and grass. Its ravages are sometimes extensive and desolating. 
The wireworms usually eat into the stalks just about the roots, and sometimes separate it from the root altogether; they seldom, however, remain so long engaged upon the one spot or portion of stalk. When they attack potatoes, they penetrate into their very hearts, and thus frequently wholly destroy the seed potatoes when newly planted; to obriate which it has been recommended to plant whole potatoes.

Amongst the green crops, turnips may be regarded as the greatest sufferers, and the tender young plants are, of course, most victimized in autumn. Multitudes of these ravenous grubs may then be found gnawing at the roots of the young turnips, and even biting off their extremities. They also frequently attack the stalk, bite it across, and when the stems fall, attack the leaves. This is, howerer, one of the least formidable of the robberies of this persevering pest, and if the wircuorms were satisfied with the leaves alone, they would not be so injurious.

We should possess some acquaintance with the natural history of such animals as we desire to destror. Such knowledge facilitates our operations, by informing us of their haunts and habits, of their dispositions and predilections, and, consequently, not only of where we are to seek for the pests, but of how we can best set to work to accomplish their destruction. Recollect, I may remark, in passing that the BEETLEs, whence the wireworms are produced, are, although not necessarily mischierous themselves, to be regarded as the grand souree of your annoyances. Let it be your care, therefore, to have these caught and destroyed; they will be chiefly found, during spring and summer, upon nettles, hemlock, fools' parsley, and other such herbs. Let this be one of your cares.

The eggs are chiefly deposited in pastures where the surface has been undisturbed, and in clover layers and fallows. There, thercfore, they make their appearance, you will find it a good plan to have your pasture eaten close by sheep. Rolling, in early spring, is also recommended, and is, in my opinion, very likely to prore serviceable, haring been preceded by a top-dressing of lime. I recommend a top-dressing of lime, salt, and soot. The proportions recommended are as follows :-Lime, 2 parts : soot, 3 parts; salt, 1 part. The salt may be purchased from salt works, or extensive dealers in that article, as spoiled salt-there being accidents which will render it unfit for market as salt, without at all militating against its value as manure, or a top-dressing. The lime should be quicklime pounded, and the mixture should be applied to the land as 
speedily as possible after having been compounded : he it also remembered that this composition will be found a valuable fertilizer, as well as a foe to insects of all sorts. Woad, sweet gale, the refuse of gas-rorks, spirits of tar, chloride of lime, nitrate of soda, mixed with the manure, will be found very serviceable; at all events, effecting a sensible diminution in the numbers of the wireworm, and of course a diminution of their ravages in an equal ratio.

The wireworm is found in great numbers, generally on newly cultivated grounds, or meadows, which have been long in repose; they can be conquered, and should not be suffered to revel on the plants of industrious farmers. Exposure to the frosts of winter will destroy them; therefore, autumn plowing is essential; and the course or remedy suggested to destroy the cutworm, is equally effective on the wireworm.

It has been tried to destroy the wireworm by flooding, but this is only a useless attempt, it being almost impossible to drown this creature, which will be found as lively as ever after a total immersion for three, or even four, days; still, however, such flooding, though it will not destroy the worms, interferes with the laying of the beetles which produce them, and will consequently, in this point of view, be occasionally found useful.

Soda has been used with success. I have known soda tried by practical men, who were most unwilling, unless actually coerced into it, to listen to any novelty, and they have unanimously asserted the success of their experiments with soda.

Let frogs and toads be encouraged on your lands; their entire food consists of insects, of such creatures as you are most anxious to destroy. Call them in, therefore, to your assistance-protect them, regard them as your friends and laborers, and they will aid you most extensively. The robin, blackbird, wagtail, thrush, together with poultry, and crows, \&c., feed on these insects.

ItLes.-In various parts of the country the iules is supposed to be, and often is called, the wireworm; but does not belong to that family; a sketch of the iules is given to correct this erroneous belief. Each segment of the body is furnished with two pairs of legs, whereas the true wireworm has but six. The iules also, when disturbed or alarmed, rolls itself into a coil which the hardness of the wireworm will not admit of. The iules is perfect in itself, and is oviparous; the wireworm is a larva and cannot produce oræ until its transformation to the beetle or perfect state. The iules 


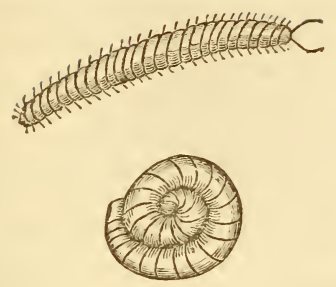

THE IULES.

consumes vegetable substances in a state of decomposition; the wireworm subsists on living roots in healthful vigor.

May-Bugs.-Among the tree-beetles those commonly called dors, chafers, May-bugs, and rose-bugs, are the most interesting to the farmer and gardener, on account of their extensive ravages, both in the winged and larva states. Besides the leaves of fruit-trees, they devour those of various forest-trees and shrubs, with an avidity not much less than that of the locust, so that, in certain seasons, and in particular districts, they become an oppressive scourge, and the source of much misery to the inhabitants.

The May-beetle is our common species. It is of a chestnutbrown color, smooth, but finely punctured, that is, covered with. little impressed dots, as if pricked with the point of a needle; each wing-case has two or three slightly elevated longitudinal lines; the breast is clothed with yellowish down. The knob of its antennæ contains only three leaf-like joints. Its average length is nine-tenths of an inch. In its perfect state it feeds on the leaves of trees, particularly on those of the cherry tree. It flies with a humming noise in the night, from the middle of May to the end of June, and frequently enters houses, attracted by the light. In the course of the spring, these beetles are often thrown from the earth by the spade and plow, in various states of maturity, some being soft and nearly white, their superabundant juices not having evaporated, while others exhibit the true color and texture of the perfect insect. The grubs devour the roots of grass and of other plants, and in many places the turf may be turned up like a carpet in consequence of the destruction of the roots. The grub is a white worm with a brownish head, and, when fully grown, is nearly as thick as the little finger. It is eaten greedily by crows and fowls. The beetles are devoured by the skunk, whose beneficial foraging is detected in $4^{*}$ 
our gardens by its abundant excrement filled with the wing-cases of these insects. The beetles may be effectually exterminated by shaking them from the trees every evening. The best time, however, for shaking trees on which the May-beetles are lodged, is in the morning, when the insects do not attempt to fly. They are most easily collected in a cloth spread under the trees to receive them when they fall, after which, they should be thrown into boiling water, to kill them, and may then be given as food to swine.
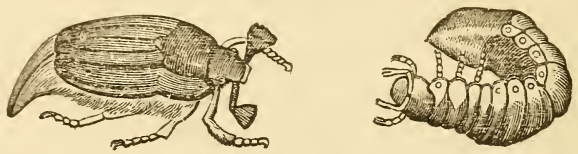

MAY-BUG.

The familiar cock chafer, or May-bug, is the parent of the grub, which is abundant in all pastures or grass fields, especially in soft regetable soils. The grub is a destructive creature, continuing its devastations for a period of three summers before its transformation. The roots of all grasses and grains are acceptable, but the roots of Indian corn furnish a feast from which they will not turn, until disturbed by the crow, who is too often unfairly abused for mischief unknown to him.

Rose Bugs.-For some time after they were first noticed, rosebugs appeared to be confined to their favorite, the blossoms of the rose; but within thirty years they have prodigiously increased in number, have attacked at random various kinds of plants in swarms, and have become notorious for their extensive and deplorable ravages. The grape-vine in particular, the cherry, plum, and apple trees, have annually suffered by their depredations; many other fruit-trees and shrubs, garden vegetables and corn, and even the trees of the forest and the grass of the fields, have been laid under contribution by these indiscriminate feeders, by whom leaves, flowers, and fruits are alike consumed. They come forth from the ground during the second week in June, and remain from thirty to forty days. At the end of this period the males become exhausted, fall to the ground, and perish, while the females enter the earth, lay their eggs, return to the surface, and, after lingering a few days, die also. The eggs laid by each female are about thirty in number, and are deposited from one to four inches beneath the surface 
of the soil; they are nearly globular, whitish and about one thirtieth of an inch in diameter, and are hatched twenty days after they are laid. The young larvæ begin to feed on such tender roots as are within their reach. When not eating, they lie upon the side, with the body curved so that the head and tail are nearly in contact; they move with difficulty on a level surface, and are continually falling over on one side or the other. They attain their full size in the autumn, being then three-quarters of an inch long, and about an eighth of an inch in diameter. They are of a yellowish white color, with a tinge of blue towards the hinder extremity, which is thick and obtuse or rounded; a few short hairs are scattered on the surface of the body; there are six short legs, namely a pair to each of the first three rings behind the head; and the latter is covered with a horny shell of a pale rust color. In October they descend below the reach of frost, and pass the winter in a torpid state. In the spring they approach towards the surface, and each one forms for itself a little cell of an oval shape, by turning round a great many times, so as to compress the earth and render the inside of the cavity hard and smooth. Within this cell the grub is transformed to a pupa, during the month of May, by casting off its skin, which is pushed downwards in folds from the head to the tail. The pupa has somewhat the form of the perfected beetle; but it is of a yellowish white color, and its short stump-like wings, its antennæ, and its legs are folded upon the breast, and its whole body is enclosed in a thin film, that wraps each part separately. During the month of June this filmy skin is rent, the included beetle withdraws from it its body and its limbs, bursts open its earthen cell, and digs its way to the surface of the ground. Thus the various changes, from the eg'g to the full development of the perfected beetle, are completed within the space of one year.

Such being the metamorphoses and habits of these insects, it is evident that we cannot attack them in the egg, the grub, or the pupa state; the enemy, in these stages, is beyond our reach. When they appear as bug's they must be crushed, scalded, or burned, to deprive them of life, for they are not affected by any of the applications usually found destructive to other insects. Experience has proved the utility of gathering them by hand, or of shaking them or brushing them from the plants into tin vessels containing a little water. They should be collected daily during the period of their visitation, and should be committed to the flames, or killed by scalding water. 
Our insect-eating birds undoubtedly devour many of these insects, and descrve to be cherished and protected for their services. Rose-bugs are also eaten greedily by domesticated fowls; and when they become exhausted and fall to the ground, or when they are about to lay their eggs, they are destroyed by moles, insects, and other animals, which lie in wait to seize them.

PEA Bug.- - In the spring of the year we often find, among seedpease, many that have holes in them ; and, if the pease have not been exposed to the light and air, we see a little insect peeping out of each of these holes, and waiting apparently for an opportunity to come forth and make its escape. If we turn out the creature from its cell, we perceive it to be a small oval beetle, rather more than one-tenth of an inch long, of a rusty black color, with a white spot on the hinder part of the thorax, four or five white dots behind the-middle of each wing-cover, and a white spot, shaped like the letter $T$, on the exposed extremity of the body. This little insect is the Bruchus Pisi of Linnæus, the pea-Bruchus, or pea-weevil, but is better known in America by the incorrect name of peabug. The original meaning of the word Bruclus is a devourer, and the insects to which it is applied well deserve this name, for, in the larva state, they devour the interior of seeds, often leaving: but little more than the hull untouched. The body is oval, and slightly convex; the head is bent downwards, so that the broad muzzle, when the insects are not eating, rests upon the breast; the antennæ are short, straight, and. saw-toothed within, and are inserted close to a deep notch in each of the eyes; the feelers, though very small, are visible; the wing-cases do not cover the end of the abdomen; and the hindmost thighs are very thick, and often notched or toothed on the under-side, as is the case in the pea-weevil. These beetles frequent the leguminous or pod-bearing plants, such as the pea, during and immediately after the flowering season; they pierce the tender pods of these plants, and commonly lay only one egg in each seed, the pulp of which suffices for the food of the little maggot-like grub hatched therein.

When the pods are carefully examined, small, discolored spots may be seen within them, each one corresponding to a similar spot on the opposite pea. If this spot in the pea be opened, a minute whitish grub, destitute of feet, will be found therein. It is the weevil in its larva form, which lives upon the marrow of the pea, and arrives at its full size by the time that the pea becomes dry. This larva or grub then bores a round hole from the hollow in the 
centre of the pea quite to the hull, but leaves the latter and generally the germ of the future sprout untouched. Hence these buggy pease, as they are called by seedsmen and gardeners, will frequently sprout and grow when planted. The grub is changed to a pupa within its hole in the pea in the autumn, and before the spring: casts its skin again, becomes a beetle, and gnaws a hole through the thin hull in order to make its escape into the air, which frequently does not happen before the pease are planted for an early crop. After the pea-vines have flowered, and while the pods are young and tender, and the pease witlin them are just beginning to swell, the beetles gather upon them, pierce the pods, and deposit their tiny eggs in the punctures. This is done only during the night, or in cloudy weather. Each egg is always placed opposite to a pea; the grubs, as soon as they are hatched, penetrate the pod and bury themselves in the pease; and the holes through which they pass are so fine as hardly to be perceived, and are soon closed. Sometimes every pea in a pod will be found to contain a weevil grub; and so great has been the injury to the crop in some parts of the country that the inhabitants have been obliged to give up the cultivation of this regetable. These insects diminish the weight of the pease in which they lodge, nearly one-half, and their leavings are fit only for the food of swine. This occasions a great loss, where pease are raised for feeding stock or for family use, as they are in many places. Those persons, who eat whole pease in the winter after they are raised, run the risk of eating the weevils also; but if the pease are kept till they are a year old, the insects will entirely leave them.

One remedy consists merely in keeping seed-pease in tight vessels over one year before planting them, or putting them, just before they are to be planted, into hot water for a minute or two, by which means the weevils will be killed, and the sprouting of the pease will be quickened. The insect is limited to a certain period for depositing its eggs ; late sown pease therefore escape its attacks. Those sown in Pennsylvania as late as the twentieth of May, are entirely free from weevils.

The Apple-Worm.-Among the insects, that have been brought to America with other productions of Europe, may be mentioned the apple-worm, as it is here called, which has become naturalized wherever the apple-tree has been introduced. This mischievous creature has sometimes been mistaken for the plum-weevil (Rhynchanus Conotrachelus Nenuphar), but it may be easily distinguished 
therefrom by its shape, its habits, and its transformations. Although the plum-weevil prefers stone firuit, it is sometimes found in apples also. On the other hand, the apple-worm has never been found here in plums. It is not a grub, but a true caterpillar, belonging to the Tortrix tribe, and in due time, is changed to a moth, called Carpocapsa Pomonella, the codling-moth, or fruit-moth of the apple. This moth is the most beautiful of the beautiful tribe to which it belongs; yet, from its habits not being known, it is seldom seen in the moth state; and the apple-grower knows no more than the man in the moon to what cause he is indebted for his wormeaten windfalls in the stillest weather.
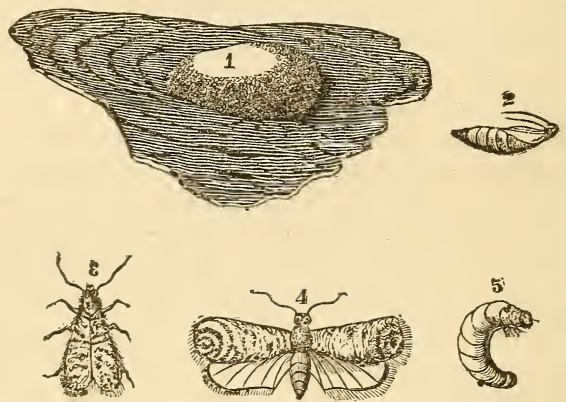

\section{APPLE-MOTH.}

At various times, between the middle of June and the first of July, the apple-worm moths may be found. They are sometimes seen in houses in the evening, trying to get through the windows into the open air, having been brought in with fruit while they were in the caterpillar state. Their fore-wings, when seen at a distance, have somewhat the appearance of brown watered silk; when closely examined they will be found to be crossed by numerous gray and brown lines, scalloped like the plumage of a bird; and near the hind angle there is a large, oval, dark brown spot, the edges of which are of a bright copper color. The head and thorax are brown mingled with gray; and the hind-wings and abdomen are light yellowish brown, with the lustre of satin. Its wings expand three quarters of an inch. This insect is readily distinguished frcm other moths by the large, oval, brown spot, edged with copper color, on the hinder margin of each of the fore-wings. During the latter 
part of June and the month of July, these fruit-moths fly about apple trees every evening, and lay their eggs on the young fruit. They do not puncture the apples, but they drop their eggs, one by one, in the eye or hollow at the blossom-end of the fruit, where the skin is most tender. They seem also to seek for early truit rather than for the late kinds, which we find are not so apt to be wormy as the thin-skinned summer apples. The eggs begin to hatch in it few days after they are laid, and the little apple-worms or caterpillars produced from them immediately burrow into the apples, making their way gradually from the eye towards the core. Commonly only one worm will be found in the same apple; and it is so small at first, that its presence can only be detected by the brownish powder it throws out in eating its way through the eye. The body of the young insect is of a whitish color; its head is heart-shaped and black; the top of the first ring or collar and of the last ring is also black; and there are eight little blackish dots or warts, arranged in pairs, on each of the other rings. As it grows older its body becomes flesh-colored; its head, the collar, and the top of the last wing, turn brown, and the dots are no longer to be seen. In the course of three weeks, or a little more, it comes to its full size, and meanwhile has burrowed to the core and through the apple in various directions. To get rid of the refuse fragments of its food, it gnaws a round hole through the side of the apple, and thrusts them out of the opening. Through this hole also the insect makes its escape after the apple falls to the ground; and the falling of the fruit is well known to be hastened by the injury it has received within, which generally causes it to ripen before its time.

Soon after the half-grown apples drop, and sometimes while they are still hanging, the worms leave them and creep into chinks in the bark of the trees or into other sheltered places, which they hollow out with their teeth to suit their shape. Here each one spins for itself a cocoon or silken case, as thin, delicate, and white as tissue paper. Most of the insects remain in their cocoons through the winter, and are not changed to moths till the following summer. The chrysalis is of a bright mahogany-brown color, and has, as usual, across each of the ring's of its hind body, two rows of prickles, by the help of which it forces its way through the cocoon before the moth comes forth.

As the apple-worms instinctively leare the fruit soon after it falls from the trees, it will be proper to gather up all wind-fallen apples 
daily, and make such immediate use of them as will be sure to kill the insects, before they have time to escape. If any old cloth is wound around or hung in the crotches of the trees, the apple-worms will conceal themselves therein; and by this means thousands of them may be obtained and destroyed, from the time when they first begin to leave the apples, until the fruit is gathered. By carefully scraping off the loose and rugged bark of the trees, in the spring, many chrysalids will be destroyed; and it has been said that the moths, when about laying their eggs, may be smothered or driven away, by the smoke of weeds burned under the trees. The worms, often found in summer pears, appear to be the same as those that affect apples, and are to be kept in check by the same means.

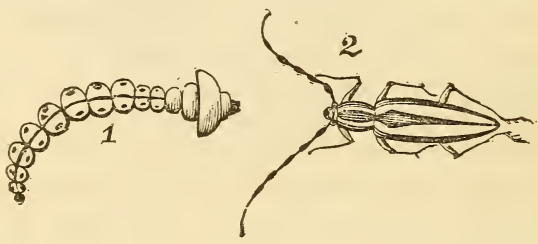

APPLE-TREE BORER.

Apple Tree Borers.-The borers of the apple tree have become notorious for their extensive ravages. They are the larvæ of a beetle called. Saperda bivittata, the two-striped, or the brown and white striped Saperda; the upper side of its body being marked with two longitudinal white stripes between three of a light brown color, while the face, the antennæ, the under-side of the body, and the legs, are white. This beetle varies in length from a little more than one-half to three-quarters of an inch. It comes forth from the trunks of the trees, in its perfected state, early in June, making its escape in the night, during which time only it uses its ample wings in going from tree to tree in search of companions and food. In the day-time it keeps at rest among the leaves of the plants which it devours. Among the trees and shrubs attacked by this borer, are the apple tree, the quince, mountain-ash, hawthorn, and other thorn bushes. In June and July the eggs are deposited, being laid upon the bark near the root, during the night. The larvæ are fleshy whitish grubs, nearly cylindrical, and tapering a little from the first ring to the end of the body. The head is small, horny, and brown; the first ring is much larger than the others, the next 
two are very short, and, with the first, are covered with punctures and very minute hairs; the following rings, to the tenth inclusive, are each furnished, on the upper and under side, with two fleshy warts situated close together, and destitute of the little rasp-like teeth, that are usually found on the grubs of the other Capricornbeetles; the eleventh and twelfth rings are very short; no appearance of legs can be seen, even with a magnifying glass of high power. The grub, with its strong jaws, cuts a cylindrical passage through the bark, and pushes its castings backwards out of the hole from time to time, while it bores upwards into the wood. The larva state continues two or three years, during which the borer will be found to have penetrated eight or ten inches upwards in the trunk of the tree, its burrow at the end approaching to, and being covered only by, the bark. Here its transformation takes place. The final change occurs about the first of June, soon after which, the beetle gnaws through the bark that covers the end of its burrow, and comes out of its place of confinement in the night. Killing it by a wire thrust into the holes it has made, is one of the oldest, safest, and most successful methods. Cutting out the grub, with a knife or gouge, is the most common practice; but it is feared that these tools have sometimes been used without sufficient caution. A third method, which has more than once been suggested, consists in plugging the holes with soft wood. If a little camphor be previously inserted, this practice promises to be more effectual ; but experiments are wanting to confirm its expediency.

Turnip Fly or Beetle.-The wary-striped flea-beetle, Haltica striolata, may be seen in great abundance on the horse-radish, various kinds of cresses, and on the mustard, and turnip, early in May, and indeed at other times throughout the summer. It is very injurious to young plants, destroying their seed-leaves as soon as the latter expand. Should it multiply to any extent, it may, in time, become as great a pest as the European turnip flea-beetle, which it closely resembles in its appearance, and in all its habits. It is considerably less than one-tenth of an inch in length. It is of a polished black color, with a broad wary buff-colored stripe on each wing-cover, and the knees and feet are reddish yellow. Specimens are sometimes found having two buff-yellow spots on each wing-cover instead of the wavy stripe.

In England, where the ravages of the turnip flea-beetle have attracted great attention, and have caused many and various experiments to be tried with a view of checking them, it is thought that 
"the careful and systematic use of lime will obviate, in a great degree, the danger which has been experienced" from this insect. From this and other statements in faror of the use of lime, there is good reason to hope that it will effectually protect plants from the various kinds of tlea-beetles, if dusted over them, when wet with dew, in proper season. Watering plants with alkaline solutions, it is said, will kill the insects without injuring the plants. The solution may be made by dissolving one pound of hard soap in twelve gallons of the soap-suds left after washing. This mixture should be applied twice a day with a water-pot. Köllar very highly recommends watering or wetting the leaves of plants with an infusion or tea of wormwood, which prevents the flea-beetles from touching them. Perhaps a decoction of walnut-leaves might be equally serviceable. Great numbers of the beetles may be caught by the skilful use of a deep bag-net of muslin, which should be swept over the plants infested by the beetles, after which the latter may be easily destroyed. This net cannot be used with safety to catch the insects on very young plants, on account of the risk of bruising or breaking their tender leaves.

Ротато FLY.-Occasionally potato-rines are very much infested by two or three kinds of Cantharides, or blistering flies, swarms of which attack and destroy the leares during midsummer. One of these kinds has thereby obtained the name of the potato-fly. It is the Cantharis vittata, or striped Cantharis. It is of a dull tawny yellow or light yellowish red color abore, with two black spots on the head, and two black stripes on the thorax and on each of the wing-covers. The under-side of the body, the leg's, and the antennæ are black, and corered with a grayish down. Its length is frons five to six tenths of an inch. The thorax is very much narrowed before, and the wing-covers are long and narrow, and cover the whole of the back. The striped Cantharis is comparatively rare in New England ; but in the Middle States it often appears in great numbers, and does much mischief in potato-fields and gardens, eating up not only the leaves of the potato, but those of many other vegetables.

Another kind of blistering fly is the ash-colored Cantharis. When the insect is rubbed, the ash-colored substance comes off, leaving the surface black. It begins to appear in gardens about the twentieth of June, and is very fond of the leaves of the English bean, which it sometimes entirely destroys. It is also occasionally found in considerable numbers on potato-vines ; and it has repeat- 
edly appeared in great profusion upon the honey-locust, which has been entirely stripped of foliage by these roracious insects. In the night, and in rainy weather, they descend from the plants, and burrow in the ground, or under leaves and tufts of grass. Thither also they retire for shelter during the heat of the day, being most actively engaged in eating in the morning and evening. About the first of August they go into the ground and lay their eggs, and these are hatched in the course of one month. The larvæ are slender, somewhat flattened grubs, of a yellowish color, banded with black, with a small reddish head, and six leg's. These grubs are very active in their motions, and appear to live upon fine roots in the ground.

About the middle of August, and during the rest of this and the following month, a jet-black Cantharis may be seen on potatovines, and also on the blossoms and leaves of various kinds of golden-rod, particularly the tall golden-rod (Solidago altissima), which seems to be its farorite food. In some places it is as plentiful in potato fields as the striped and the margined Cantharis, and by its serious ravages has often excited attention. These three kinds, in fact, are often confounded under the common name of potato-flies. These insects are taken, in considerable quantities, by brushing or shaking them from the potato-vines into a broad tin pan, from which they are emptied into a covered pail containing a little water in it, which, by wetting their wings, prevents their flying out when the pail is uncovered. The same method may be employed for taking the other kinds of Cantharides, when they become troublesome and destructire from their numbers; or they may be caught by gently sweeping the plants they frequent with a deep muslin bag-net. They should be killed by throwing them into scalding water, for one or two minutes, after which they may be spread out on sheets of paper to dry, and may be made profitable by selling them to the apothecaries for medical use.

Grasshoppers axd Locests.-Most grasshoppers are of a green color, and âre furnished with wingss and wing-covers, the latter frequently resembling the leaves of trees, upon which, indeed, many of these insects pass the greater part of their lives. Their leaf-like form and green color evidently seem to have been designed for the better concealment of these insects. They commit their egos to the earth, dropping them into holes made for this purpose by their piercers. They lay a large number of eg's at a time, and cover them with a kind of varnish, which, when dry, forms a thin film 
that completely encloses them. Their eges are laid in the autumn, and usually are not hatched till the following spring. They are nocturnal insects, or at least more active by night than by day. When taken between the fingers, they emit from their mouths a considerable quantity of dark-colored fluid, as do also the locusts or diurnal grasshoppers. They devour the leaves of trees, and of other plants, and lead a solitary life, or at least do not associate and migrate from place to place in great swarms, likeg some of the crickets and the locusts.

Locests.-The various insects included under the name of locusts nearly all agree in having their wing-covers rather long and narrow, and placed obliquely along the sides of the body, meeting, and even overlapping for a short distance, at their upper edges, which together form a ridge on the back like a sloping roof. Their antennæ are much shorter than those of most grasshoppers, and do not taper towards the end, but are nearly of equal thickness at both extremities. Their feet have really only three joints; but as the under-side of the first joint is marked by one or two cross lines, the fcet, when seen only from below, seem to be four or five jointed.

Although the ravages of locusts in America are not followed by such serious consequences as in the Eastern continent, yet they are sufficiently formidable to have attracted attention, and not unfrequently have these insects laid waste considerable tracts, and occasioned no little loss to the cultivator of the soil. Our salt-marshes, which are accounted among the most productive and valuable of our natural meadows, are frequented by great numbers of the small red-legged species (Acrydium femur-rubrum), intermingled occasionally with some larger kinds. These, in certain seasons, almost entirely consume the grass of these marshes, from whence they then take their course to the uplands, devouring, in their way, grass, corn, and vegetables, till checked by the early frosts, or by the close of the natural term of their existence. When a scanty crop of hay has been gathered from the grounds which these puny pests have ravaged, it becomes so tainted with the putrescent bodies of the dead locusts contained in it, that it is rejected by horses and cattle. In this country locusts are not distinguished from grasshoppers, and are generally, though incorrectly, comprehended under the same name, or under that of flying grasshoppers. They are, however, if we make allowance for their inferior size, quite as voracious and injurious to vegetation during the young or larva and pupa states, when they are not provided with wings, as they are 
when fully grown. During dry seasons, they often appear in great multitudes, and are the greedy destroyers of the half-parched herbage. In many parts of the United States these locusts appear in myriads, and their devastations in dry seasons are horrible. The locusts may be taken by means of a piece of stout cloth, carried by four persons, two of whom draw it rapidly along, so that the edge may sweep over the surface of the soil, and the two others hold up the cloth behind at an angle of forty-five degrees. This contrivance seems to operate somewhat like a horse-rake, in gathering the insects into winrows or heaps, from which they are speedily transferred to large sacks. When these insects are very prevalent, it will be advisable to mow the grass early, so as to secure a crop before it has suffered much loss. The time for doing this will be determined by the period when the most destructive species come to maturity during the latter part of July. If then, the meadows are mowed about the first of July, the locusts, being at that time small and not provided with wings, will be unable to migrate, and will consequently perish on the ground for the want of food, while a tolerable crop of hay will be secured, and the marshes will suffer less from the insects during the following summer. This, like all other preventive measures, must be generally adopted, in order to prove effectual; for it will avail a farmer but little to take preventive measures on his own land, if his neighbors, who are equally exposed and interested, neglect to do the same. Many birds devour them, particularly our domestic fowls, which eat great numbers of grasshoppers, locusts, and even crickets. Young turkeys, if allowed to go at large during the summer, derive nearly the whole of their subsistence from these insects. The great increase of these and other noxious insects may fairly be attributed to the exterminating war which has wantonly been waged upon our insect-eating biris, and we may expect the evil to increase unless these little friends of the farmer are protected, or left undisturbed to multiply, and follow their natural habits. Meanwhile, some advantage may be derived from encouraging the breed of our domestic fowls. A flock of young chickens or turkeys, if suffered to go at large in a garden, while the mother is confined within their sight and hearing, under a suitable crate or cage, will devour great numbers of destructive insects; and our farmers should be urged to pay more attention than heretofore to the rearing of chickens, young turkeys, and ducks, with a view to the benefits to be derived from their destruction of insects. 
Plaxt Lice.-The Aphidians, in which group we include the insects commonly known by the name of plant-lice, differ remarkably from all the foregoing in their appearance, their formation, and their manner of increase. Their bodies are very soft, and usually more or less oval.

Aphides, or plant-lice as they are usually called, are among the most extraordinary of insects. They are found upon almost all parts of plants, the roots, stems, young shoots, buds, and leaves, and there is scarcely a plant which does not harbor one or two kinds peculiar to itself. They are, moreover, exceedingly prolific, for one individual, in five generations, may become the progenitor of nearly six thousand millions of descendants. It often happens that the succulent extremities and stems of plants will, in an incredibly short space of time, become completely coated with a living mass of these little lice. These are usually wingless, consisting of the young and of the females only; for winged individuals appear only at particular seasons, usually in the autumn, but sometimes in the spring, and these are small males and larger females. After pairing, the latter lay their eggs upon or near the leaf-buds of the plant upon which they live, and, together with the males, soon afterwards perish.

The winged plant-lice provide for a succession of their race by stocking the plants with eggs in the autumn. These are hatched in due time in the spring, and the young lice immediately begin to pump up sap from the tender leaves and shoots, increase rapidly in size, and in a short time come to maturity. In this state, it is found that the brood, without a single exception, consists wholly of females, which are wingless, but are in a condition immediately to continue their kind. Their young, however, are not hatched from eggs, but are produced alive, and each female may be the mother of fifteen or twenty young lice in the course of a single day. The plant-lice of this second generation are also wingless females, which grow up and have their young in due time; and thus brood after brood is produced, even to the seventh generation or more, without the appearance or intervention, throughout the whole season, of a single male. This extraordinary kind of propagation ends in the autumn with the birth of a brood of males and females, which in due time acquire wings and pair ; eggs are then laid by these females, and with the death of these winged individuals, which soon fullows, the race becomes extinct for the season.

The peach-tree suffers very much from the attacks of plant-lice, 
which live under the leaves, causing them by their punctures to become thickened, to curl, or form hollows beneath, and corresponding crispy and reddish swellings above, and finally to perish and drop off prematurely. The depredations of these lice is one of the causes, if not the only cause of the peculiar malady affecting the peach-tree in the early part of summer, and called the blight. Plant-lice produce a blight of apple-trees occasionally.

The injuries occasioned by plant-lice are much greater than would at first be expected from the small size and extreme weakness of the insects; but these make up by their numbers what they want in strength individually, and thus become formidable enemies to vegetation. By their punctures, and the quantity of sap which they draw from the leaves, the functions of these important organs are deranged or interrupted, the food of the plant, which is there elaborated to nourish the stem and mature the fruit, is withdrawn, before it can reach its proper destination, or is contaminated and left in a state unfitted to supply the wints of vegetation. Plants are differently affected by these insects. Some wither and cease to grow, their leaves and stems put on a sickly appearance, and soon die from exhaustion. Others, though not killed, are greatly impeded in their growth, and their tender parts, which are attacked, become stunted, curled, or warped. The punctures of these lice seem to poison some plants, and affect others in a most singular manner, producing warts or swellings, which are sometimes solid and sometimes hollow, and contain in their interior a swarm of lice, the descendants of a single individual, whose punctures were the original cause of the tumor.

When trees are infected, scrape off all the rough bark of the infected trees, and make them perfectly clean and smooth early in the spring; then rub the trunk and limbs with a stiff brush wet with a solution of potash as hereafter recommended for the destruction of bark-lice; after which remove the sods and earth around the bottom of the trunk, and with the scraper, brush, and alkaline liquor cleanse that part as far as the roots can conveniently be uncovered. The earth and sods should immediately be carried away, fresh loam should be placed around the roots, and all cracks and wounds should be filled with grafting cement or clay mortar. Small limbs and extremities of branches, if infected, and beyond reach of the applications, should be cut off and burned.

This insect is mischievous and destructive to well grown and ripening grass plants; its minute character has allowed it to escape 
the notice of the farmers generally, until recently, when its ravages on grass fields, reserved for hay, have exhibited their depredations, brown spots or areas, the herbage having been destroyed by these voracious creatures; these minute insects are countless in number, and need the observance and study of every careful farmer.

BARK-Lice.-These insects vary very much in form; some of them are oval and slightly convex scales, and others have the shape of a muscle; some are quite convex, and either formed like a boat turned bottom upwards, or are kidney shaped, or globular. They live mostly on the bark of the stems of plants, some however, are habitually found upon leaves, and some on roots. Early in the spring the bark-lice are found apparently torpid, situated longitudinally in regard to the branch, the head upwards, and sticking by their flattened inferior surface closely to the bark. On attempting: to remove them they are generally crushed, and there issues from the body a dark colored fluid. By pricking them with a pin, they can be made to quit their hold. A little later the body is more swelled, and, on carefully raising it with a knife, numerous oblong eggs will be discovered beneath it, and the insect appears dried up and dead, and only its outer skin remains, which forms a convex cover to its future progeny. Under this protecting shield the young are hatched, and, on the approach of warm weather, make their escape at the lower end of the shield, which is either slightly el vated or notched at this part. They then move with considerable activity, and disperse themselves over the young shoots or leaves. These young lice insert their beaks into the bark or leaves, and draw from the cellular substance the sap that nourishes them. Young apple trees, and the extremities of the limbs of older trees are very inuch subject to the attacks of a small species of barklouse. The limbs and smooth parts of the trunks are sometimes completely covered with these insects, and present a very singularly wrinkled and rough appearance from the bodies which are crowded closely together. In the winter these insects are torpid, and apparently dead. These insects have now become extremely common, and infest our nurseries and young trees to a very great extent.

The best application for the destruction of the lice is a wash made of two parts of soft soap and eight of water, with which is to be mixed lime enough to bring it to the consistence of thick whitewash. This is to be put upon the trunks and limbs of the trees with a brush, and as high as practicable, so as to cover the whole 
surface, and fill all the cracks in the bark. The proper time for washing over the trees is in the early part of June, when the insects are young and tender. These insects may also be killed by using in the same way a solution of two pounds of potash in seven quarts of water, or a pickle consisting of a quart of common salt in two gallons of water.

Peach Tree Borer.-The permicious borer, which, during many years past, has proved very destructive to peach-trees throughout the United States, is a species of AEgeria, named exitiosa, or the destructive. The eggs, from which these borers are hatched, are deposited, in the course of the summer, upon the trunk of the tree near the root; the borers penetrate the bark, and devour the inner bark and sap-wood. The seat of their operations is known by the castings and gum which issue from the holes in the tree. When these borers are nearly one year old, they make their cocoons either under the bark of the trunk or of the root, or in the earth and gum contiguous to the base of the trees; soon afterwards they are transformed to chrysalids, and finally come forth in the winged state, and lay the eggs for another generation of borers. The last transformation takes place from June to October. Hence borers, of all sizes, will be found in the trees throughout the year, although it seems to be necessary that all of them, whether more or less advanced, should pass through one winter before they appear in the winged state.

As a remedy remove the earth around the base of the tree, crush and destroy the cocoons and borers which may be found in it, and under the bark, cover the wounded parts with common clay composition or mortar, and surround the trunk with a strip of sheathing-paper eight or nine inches wide, which should extend two inches below the level of the soil, and be secured with strings of matting above. Fresh mortar should then be placed around the root, so as to confine the paper and prevent access beneath it, and the remaining cavity may be filled with new or unexhausted loam. This operation should be performed in the spring or during the month of June. In the winter the strings may be removed, and in the following spring the trees should again be examined for any borers that may have escaped search before, and the protecting applications should be renewed. 


\section{CATERPILLARS.}

Yellow Bear Caterpillar.-Of all the hairy caterpillars frequenting our gardens, there are none so common and troublesome in the Northern States as that called the yellow bear by Harris. Like most of its genus it is a very general feeder, devouring almost all kinds of herbaceous plants, with equal relish, from the broadleared plantain at the door-side, the peas, beans, and even the flowers of the garden, and the corn and coarse grasses of the fields, to the leaves of the vine, the currant, and the gooseberry, which it does not refuse when pressed by hunger. This kind of caterpillar varies very much in its colors; it is perhaps most often of a pale yellow or straw color, with a black line along each side of the body, and a transverse line of the same color between each of the segments or rings, and it is covered with long pale yellow hairs. Others are often seen of a rusty or brownish yellow color, with the same black lines on the sides and between the rings, and they are clothed with foxy red or light brown hairs. The head and ends of the feet are ochre-yellow, and the under-side of the body is blackish in all the varieties. They are to be found of different ages and sizes from the first of June till October. When fully grown they are about two inches long, and then creep into some convenient place of shelter, make their cocoons, in which they remain in the chrysalis state during the winter, and are changed to moths in the months of May or June following. Some of the first broods of these caterpillars appear to come to their growth early in summer, and are transformed to moths by the end of July or the beginning: of August, at which time I have repeatedly taken them in the winged state; but the greater part pass through their last change in June. The moth is familiarly known by the name of the white miller, and is often seen about houses. Its scientific name is $A r c-$ tia Virginica. It is white, with a black point on the middle of the fore-wings, and two black dots on the hind-wings, one on the middle and the other near the posterior angle, much more distinct on the under than on the upper side; there is a row of black dots on the top of the back, another on each side, and between these a longitudinal deep yellow stripe ; the hips and thighs of the fore-leg's are also ochre-yellow. It expands from one inch and a half to two inches. Pick off the caterpillars from day to day and crush then, and do not spare "the pretty white millers," frequently found on the fences, or on the plants, laying their golden yellow eggs. 
The Salt-marsh Caterpillar, an insect by far too well known on our sea-board, and now getting to be conmonon in the interior, closely resembles the yellow bear in some of its varieties. These appear toward the end of June, and grow rapidly from that time till the first of August. During this month they come to their full size, and begin to run, as the phrase is, or retreat from the marshes, and disperse through the adjacent uplands, often committing very extensive ravages in their progress. Corn-fields, gardens, and even the rank weeds by the way-side afford them temporary nourishment while wandering in search of a place of security from the tide and weather. They conceal themselves in walls, under stones, in hay-stacks and mows, in wood-piles, and in any other places in the.r way, which will afford them the proper degree of shelter during the winter. Here they make their coarse hairy cocoons, and change to chrysalids, in which form they remain till the following summer, and are transformed to moths in the month of June. In those cases where, from any cause, the caterpillars, when arrived at maturity, have been unable to leave the marshes, they conceal themselves beneath the stubble, and there make their cocoons. Such, for the most part, is the course and duration of the lives of these insects in the Northern States; but in the Middle and Southern States two broods are brought to perfection annually; and even here some of them run through their course sooner, and produce a second brood of caterpillars in the same season. The full-grown caterpillar measures one inch and three quarters or more in length. It is clothed with long hairs, which are sometimes black and sometimes brown on the back and forepart of the body, and of a lighter brown color on the sides. The hairs grow in spreading clusters from warts, which are of a yellowish color in this species. The body, when stripped of the hairs, is yellow, shaded at the sides with black, and there is a blackish line extending along the top of the back. The breathing-holes are white, and very distinct even through the hairs. These caterpillars, when feeding on the marshes, are sometimes overtaken by the tide, and when escape becomes im possible, they roll themselves up in a circular form, and abandon themselves to their fate. The hairs on their bodies seem to have a repelling power, and prevent the water from wetting their skins, so that they float on the surface, and are often carried by the waves to distant places, where they are thrown on shore, and left in winrows with the wash of the sea. After a little time most of them recover from their half-drowned condition, and begin their depre- 
dations anew. In this way these insects seem to have spread from the places where they first appeared to others at a considerable distance.

In order to lessen the ravages of the salt-marsh caterpillars, and to secure a fair crop of hay when these insects abound, the marshes should be mowed early in July, at which time the caterpillars are small and feeble, and being unable to wander far, will die before the crop is gathered in. In defence of early mowing, it may be said that it is the only way by which the grass may be saved in those meadows where the caterpillars have multiplied to any extent; and, if the practice is followed generally, and continued during several years in succession, it will do much towards exterminating these destructive insects. By the practice of late mowing, where the caterpillars abound, a great loss in the crop will be sustained, immense numbers of caterpillars and grasshoppers will be left to grow to maturity and disperse upon the uplands, by which means the evil will go on increasing from year to year; or they will be brought in with the hay to perish in our barns and stacks, where their dead bodies will prove offensive to the cattle, and occasion a waste of fodder. To get rid of "the old fog" or stubble, which becomes much thicker and longer in consequence of early mowing, the marshes should be burnt over in March. The roots of the grass will not be injured by burning the stubble, on the contrary they will be fertilized by the ashes; while great numbers of roung grasshoppers, cocoons of caterpillars, and various kinds of destructive insects, with their eggs, concealed in the stubble, will be destroyed by the fire. In the Province of New Brunswick, the benefit arising from burning the stubble has long been proved.

Of the caterpillars which devour the leaves of trees, the most common and destructive are the little caterpillars known by the name of fall web-worms, whose large webs, sometimes extending over entire branches with their leaves, may be seen on our native elms, and also on apple and other fruit trees, in the latter part of summer. The egos, from which these caterpillars proceed, are laid by the parent moth in a cluster upon a leaf near the extremity of a branch; they are hatched from the last of June till the middle of August, some broods being early and others late, and the young caterpillars immediately begin to provide a shelter for themselves, by covering the upper side of the leaf with a web, which is the result of the united labors of the whole brood. They feed in company beneath this web, devouring only the upper skin and pulpy 
portion of the leaf, leaving the veins and lower skin of the leaf untouched. As they increase in size, they enlarge their web, carrying it over the next lower leaves, all the upper and pulpy parts of which are eaten in the same way, and thus they continue to work downwards, till finally the web covers a large portion of the branch, with its dry, brown, and filmy foliage, reduced to this unseemly condition by these little spoilers. These caterpillars when fully grown, measure rather more than one inch in length; their budies are slender and are very thinly clotherl with hairs of a grayish color, intermingled with a few which are black. The general color of the body is greenish yellow dotted with black; there is a broad blackish stripe along the top of the back, and a bright yellow stripe on each side. The warts, from which the thin bundles of spreading, silky hairs proceed, are black on the back, and rust-yellow or orange on the sides. The head and feet are black. Towards the end of August and during the month of September they leare the trees, disperse, and wander about, eating such plants as happen to lie in their course, till they have found suitable places for shelter and concealment where they make their thin and almost transparent cocoons, composed of a slight web of silk intermingled with a few hairs. They remain in the cocoons in the chrysalis state through the winter, and are transformed to moths in the months of June and July. These moths are white, and without spots; the forethighs are tawny-yellow, and the feet blackish. Their wings expand from one inch and a quarter to one inch and three eighths. Their antennæ and feelers do not differ essentially from those of the majority of the Arctians, the former in the males being doubly feathered beneath, and those of the females having two rows of minute teeth on the under-side. The only time in which we can attempt to exterminate these destructive insects with any prospect of success, is when they are young and just beginning to make their webs on the trees. So soon, then, as the webs begin to appear on the extremities of the branches, they should be stripped off, with the few leares which they corer, and the caterpillars contained therein, at one grasp, and should be crushed under foot.

Apple-Tree Caterpillars.-During the months of July and August, there may be found on apple-trees and rose-bushes little slender caterpillars of a bright yellow color, sparingly clothed with long and fine yellow hairs on the sides of the body, and having four short and thick brush-like yellowish tufts on the back, that is on the fourth and three following rings, two long black plumes or 
peneils extending forwards from the first ring, and a single plume on the top of the eleventh ring. The head, and the two little retractile warts on the ninth and tenth rings are coral red; there is a narrow black or brownish stripe along the top of the back, and a wider dusky stripe on each side of the body. These pretty caterpillars do not ordinarily herd together, but sometimes our appletrees are much infested by them. When they have done eating, they spin their cocoons on the leaves, or on the branches or trunks of the trees, or on fences in the vicinity. The chrysalis is not only beset with little hairs or down, but has three oval clusters of branny scales on the back. In about eleven days after the change to the chrysalis is effected, the last transformation follows, and the insects come forth in the adult state, the females wingless, and the males with large ashen-gray wings, crossed by wary darker bands on the upper pair, on which, moreover, is a small black spot near the tip, and a minute white crescent near the outer hind angle. The body of the male is small and slender, with a row of little tufts along the back, and the wings expand one inch and three eighths. The females are of a lighter gray color than the males, their bodies are very thick, and of an oblong oval shape, and, though seemingly wingless, upon close examination two little scales, or stinted winglets, can be discovered on each shoulder. These females lay their egg's upon the top of their cocoons, and cover them with a large quantity of frothy matter, which on drying becomes white and brittle. Different broods of these insects appear at various times in the course of the summer, but the greater number come to maturity and lay their eggs in the latter part of August, and the beginning of September; and these eggs are not hatched till the following summer. The name of this moth is Orgyia leucostigma, the white-marked Orgyia or tussock-moth. In Hovey's Gardener's Magazine Mr. Ires states, that on passing through an apple orchard in February, he "perceived nearly all the trees speckled with occasional dead leaves, adhering so firmly to the branches as to require considerable force to dislodge them. Each leaf covered a smail patch of from one to two hundred egg's, united together, as well as to the leaf, by a gummy and silken fibre, peculiar to the moth." In March he "visited the same orchard, and, as an experiment, cleared three trees, from which he took twenty-one bunches of eggs. The remainder of the trees he left untouched until the tenth of May, when he found the caterpillars were hatched from the eggs, and had commenced their slow but sure ravages. He watched them from 
time to time, until many branches had been spoiled of their leaves, and in the autumn were entirely destitute of firuit; while the three trees, which had been stripped of the eggss, were flush with foliage, each limb, without exception, ripening its fruit." These pertinent remarks point out the nature and extent of the evil, and suggest the proper remedy to be used against the ravages of these insects.

LACKEY CATERPILLAR. - There is a kind of caterpillars that swarm in the unpruned nurseries and neglected orchards of the slovenly husbandman, and hang their many-coated webs upon the wild cherry trees that are suffered to spring up unchecked by the way-side and encroach upon the borders of our pastures and fields. The eggs from which they are hatched, are placed around the ends of the branches, forming a wide kind of ring or bracelet, consisting of three or four hundred eggs, in the form of short cylinders standing on their ends close together, and corered with a thick coat of brownish water-proof varnish. The caterpillars come forth, with the unfolding of the leaves of the apple and cherry tree, during the latter part of April or the beginning of May. The first signs of their activity appear in the formation of a little angular web or tent, somewhat resembling a spider's web, stretched between the forks of the branches a little below the cluster of eggs. Under the shelter of these tents, in making which they all work together, the caterpillars remain concealed at all times when not engaged in eating. In crawling from twig to twig and from leaf to leaf, they spin from their mouths a slender silken thread, which is a clue to conduct them back to their tents; and as they go forth and return in files, one after another, their pathways in time become well carpeted with silk, which serves to render their footing secure during their frequent and periodical journeys in rarious directions, to and from their common habitation. As they increase in age and size, they enlarge their tent, surrounding it, from time to time, with new layers or webs, till, at length, it acquires a diameter of eight or ten inches. They come out together at certain stated hours to eat, and all retire at once when their regular meals are finished; during bad weather, however, they fast, and do not venture from their shelter. These caterpillars are of a kind called lackeys. When fully grown they measure about two inches in length. Their heads are black; extending along the top of the back, from one end to the other, is a whitish line, on each side of which, on a yellow ground, are numerous short and fine crinkled black lines, that, lower down, become mingled together, and form a broad longitu- 
dinal black stripe, or rather a row of long black spots, one on each ring, in the middle of each of which is a small blue spot; below this is a narrow wary yellow line, and lower still the sides are variegated with fine intermingled black and yellow lines, which are lost at last in the general dusky color of the under-side of the body; on the top of the eleventh ring is a small blackish and hairy wart, and the whole body is very sparingly clothed with short and soft hairs, rather thicker and longer upon the sides than elsewhere. From the first to the middle of June they begin to leave the trees upon which they have hitherto lived in company, separate from each other, wander about awhile, and finally get into some crevice or other place of shelter, and make their cocoons. These are of a regular long oval form, composed of a thin and very loosely woven web of silk, the meshes of which are filled with a thin paste, that on drying is changed to a yellow powder, like flour of sulphur in appearance. Some of the caterpillars, either from weakness or some other cause, do not leave their nests with the rest of the swarm, but make their cocoons there, and when the webs are opened these cocoons may be seen intermixed with a mass of blackish grains, like gunpowder, excreted by the caterpillars during their stay. From fourteen to seventeen days after the insect has made its cocoon and changed to a chrysalis, it bursts its chrysalis skin, forces its way through the wet and softened end of its cocoon, and appears in the winged or miller form.

The moth of the lackey-caterpillar is of a rusty or reddish brown color, more or less mingled with gray on the middle and base of the fore-wings, which, besides, are crossed by two oblique, straight, dirty white lines. It expands from one inch and a quarter, to one inch and a half, or a little more. The moths appear in great numbers in July, flying about and often entering houses by night. At this time they lay their eggs, selecting the wild cherry, in preference to all other trees, for this purpose, and, next to these, appletrees. These insects, because they are the most common and most abundant in all parts of our country, and have obtained such notoriety that in common language they are almost exclusively known among us by the name of the catcrpillars, are the worst enemies of the orchard. Where proper attention has not been paid to the destruction of them, they prevail to such an extent as almost entirely to strip the apple and cherry trees of their foliage, by their attacks continued during the seven weeks of their life in the caterpillar form. The trees, in those orchards and gardens where they 
have been suffered to breed for a succession of years, become prematurely old, in consequence of the efforts they are obliged to make to repair, at an unseasonable time, the loss of their foliage, and are rendered unfruitful, and consequently unprofitable. But this is not all; these pernicious insects spread in every direction, from the trees of the careless and indolent, to those of their more careful and industrious neighbors, whose labors are thereby greatly increased, and have to be followed up year after year, without any prospect of permanent relief.

Many methods and receipts for the destruction of these insects have been published and recommended, but have failed to exterminate them, and indeed have done but little to lessen their numbers. The great difficulty is the neglect to do any thing, till after the caterpillars have covered the trees with their nests. Then the labors of the sluggard commence, and one tree, let his receipt be ever so perfect and powerful, will cost him as much time and labor as ten trees would have required three weeks sooner. The means to be employed may be stated under three heads. The first is, the collection and destruction of the eggs. These should be sought for in the winter and the early part of spring, when there are no leaves on the trees. They are easily discorered at this time, and may be removed with the thumb-nail and fore-finger. Nurseries and the lower limbs of large trees may thus be entirely cleared of the clusters of eggs during a few visits made at the proper season. If a liberal bounty for the collection of the eggs were to be offered, and continued for the space of ten years, these destructive caterpillars would be nearly exterminated at the end of that time. Under the second head are to be mentioned the most approved plans for destroying the caterpillars after they are hatched, and have begun to make their nests or tents. It is well known that the caterpillars come out to feed twice during the day-time, namely, in the forenoon and afternoon, and that they rarely leave their nests before nine in the morning, and return to them again at noon: During the early part of the season, while the nests are small, and the caterpillars young and tender, and at those hours when the insects are gathered together within their common habitation, they may be effectually destroyed by crushing them by hand in the nests. A brush, somewhat like a bottle-brush, fixed to a long handle, a dried mullein head and its stalk fastened to a pole, will be useful to remove the nests, with the caterpillars contained therein, from those branches which are too high to be reached by hand. In5 * 
stead of the brush, we may use, with nearly equal success, a smal] mop or sponge, dipped as often as necessary into a pailful of refuse soap-suds, strong white-wash, or cheap oil. The mop should be thrust into the nest and turned round a little, so as to wet the caterpillars with the liquid, which will kill every one that it touches. These means, to be effectual, should be employed during the proper hours, that is, early in the morning, at mid-day, or at night, and as soon in the spring as the caterpillars begin to make their nests; and they should be repeated as often at least, as once a week, till the insects leave the trees. Early attention and perseverance in the use of these remedies will, in time, save the farmer hundreds of dollars, and abundance of mortification and disappointment, besides rewarding him with the grateful sight of the verdant foliage, snowy blossoms, and rich fruits of his orchard in their proper seasons. Under the third head, declare war against these caterpillars, a war of extermination, to be waged annually during the month of May and the beginning of June. Let every able-bodied citizen, who is the owner of an apple or cherry tree, cultivated or wild, within our borders, open the campaig'n in May, and give battle to the common enemy. If every man is prompt to do his duty, the enemy will be completely conquered.

Locust-Tree Borers. - The locust-tree, Robinia pseudacacia, is preyed upon by three different kinds of wood-eaters or borers, whose unchecked ravages seem to threaten the entire destruction and extermination of this valuable tree within this part of the United States. One of these borers is a little reddish caterpillar, whose operations are confined to the small branches and to very young trees, in the pith of which it lives; and by its irritation it causes the twig to swell around the part attacked. These swellings, being spongy and also perforated by the caterpillar, are weaker than the rest of the stem, which therefore easily breaks off at these places.

The second kind of borer of the locust-tree is larger than the foregoing, is a grub, and not a caterpillar, which finally turns to the betle named Clytus pictus, the painted Clytus. In the month of September these beetles gather on the locust-trees. Having paired, the female creeps over the bark, searching the crevices with her antennæ, and dropping therein her snow-white eggs, in clusters of seven or eight together, and at intervals of five or six minutes, till her whole stock is safely stored. The eggrs are soon hatched, and the grubs immediately burrow into the bark, devouring the soft inner substance that suffices for their nourishment till the approach 
of winter, during which they remain at rest in a torpid state. In the spring they bore through the sap-wood, more or less deeply into the trunk, the general course of their winding and irregular passages being in an upward direction from the place of their entrance. For a time they cast their chips out of their holes as fast as they are made, but after a while the passage becomes clogged and the burrow more or less filled with the coarse and fibrous fragments of wood, to get rid of which the grubs are often obliged to open new holes through the bark. The seat of their operations is known by the oozing of the sap and the dropping of the saw-dust from the holes. The bark around the part attacked begins to swell, and in a few years the trunks and limbs will become disfigured and weakened by large porous tumors, caused by the efforts of the trees to repair the injuries they have suffered. The grubs attain their full size by the twentieth of July, soon become pupæ, and are changed to beetles and leave the trees early in September. Thus the existence of this species is limited to one year.

White-washing, and covering the trunks of the trees with grafting composition, may prevent the female from depositing her eggs upon them ; but this practice cannot be carried to any great extent in plantations or large nurseries of the trees. Perhaps it will be useful to head or cut down young trees to the ground, with the view of destroying the grubs contained in them, as well as to promote a more vigorous growth. Much evil might be prevented by employing children to collect the beetles while in the act of providing for the continuation of their kind. A common black bottle, containing a little water, would be a suitable vessel to receive the beetles as fast as they were gathered, and should be emptied into the fire in order to destroy the insects. The gathering should be begun as soon as the beetles first appear, and should be continued as long as any are found on the trees, and furthermore should be made a general business for several years in succession. I have no doubt, should this be done, that, by devoting one hour every day to this object, we may, in the course of a few years, rid ourselves of this destructive insect.

The third of the wood-eaters, to which the locust-tree is exposed, though less common than the others, and not so universally destructive to the tree as the painted Clytus, is a very much larger borer, and is occasionally productive of great injury, especially to full-grown and old trees, for which it appears to have a preference. It is a true caterpillar, belonging to the tribe of moths under con- 
sideration, is reddish above, and white beneath, with the head and top of the first ring brown and shelly, and there are a few short hairs arising from minute warts thinly scattered over the surface of the body. When fully grown, it measures two inches and a half, or more, in length, and is nearly as thick as the end of the little finger. These caterpillars bore the tree in various directio:s, but for the most part obliquely upwards and downwards through the solid wood, enlarging the holes as they increase in size, and continuing them through the bark to the outside of the trunk. Before transforming, they line these passages with a web of silk, and, retiring to some distance from the orifice, they spin around their bodies a closer web, or cocoon, within which they assume the chrysalis form. The chrysalis measures one inch and a half or two inches in length, is of an amber color, changing to brown on the forepart of the body; and, on the upper side of each abdominal ring, are two transverse rows of tooth-like projections. By the help of these, the insect, when ready for its last transformation, works its way to the mouth of its burrow, where it remains while the chrysalis skin is rent, upon which it comes forth on the trunk of the tree a winged moth. In this its perfected state, it is of a gray color; the fore-wings are thickly covered with dusky netted lines and irregular spots, the hind-wings are more uniformly dusky, and the shoulder-covers are edged with black on the inside. It expands about three inches. The male, which is much smaller, and has been mistaken for another species, is much darker than the female, from which it differs also in having a large ochre-yellow spot on the hind-wings, contiguous to their posterior margin. Professor Peck, who first made public the history of this insect, named it Cossus Rcbinice, the Cossus of the locust-tree. It is supposed by Professor Peck to remain three years in the caterpillar state. The moth comes forth about the middle of July.

Our fruit-trees seem to be peculiarly subject to the ravages of insects, probably because the native trees of the forest, which originally yielded the insects an abundance of food, have been destroyed to a great extent, and their places supplied only partially by orchards, gardens, and nurseries. Numerous as are the kinds of caterpillars now found on cultivated trees, some are far more abundant than others, and therefore more often fall under our observation, and come to be better known. Such, for instance, are certain gregarious caterpillars that swarm on the apple, cherry, and plum-trees towards the end of summer, stripping whole branches of their 
leaves, and not unfrequently despoiling our rose-bushes and thornhedges also. These caterpillars are of two kinds, very different in appearance, but alike in habits and destructive propensities. The first of these may be called the red-humped, a name that will probably bring these insects to the remembrance of those persons who have ever observed them. Different broods make their appearance at various times during August and September. The eggs, from which they proceed, are laid, in the course of the month of July, in clusters on the under-side of a leaf, generally near the end of a branch. When first hatched they eat only the substance of the under-side of the leaf, leaving the skin of the upper-side and all the veins untouched; but as they grow larger and stronger they devour whole leaves from the point to the stalk, and go from leaf to leaf down the twig's and branches. The young caterpillars are lighter colored than the old ones, which are yellowish-brown, paler on the sides, and longitudinally striped with slender black lines; the head is red; on the top of the fourt? ring there is a bunch or hump, also of a red color; along the back are several short black prickles; and the hinder extremity tapers somewhat, and is always elevated at an angle with the rest of the body, when the insect is not crawling. The full-grown caterpillars measure one inch and a quarter, or rather more, in length. The rest close together on the twigs, when not eating, and sometimes entirely cover the small twigs and ends of the branches. The early broods come to their growth and leave the trees by the middle of August, and the others between this time and the latter part of September. All the caterpillars of the same brood descend at one time, and disappear in the night. They conceal themselves under leaves, or just beneath the surface of the soil, and make their cocoons. They remain a long time in their cocoons before changing to chrysalids, and are transformed to moths towards the end of June or the beginning of July. Mr. Abbot states that in Georgia these insects breed twice a year, the first broods making their cocoons towards the end of May, and appearing in the winged form fifteen days afterwards. This, a Notodonta, is a neat and trim looking moth, and is of a light brown color; the fore-wings are dark brown along the inner margin, and more or less tinged with gray before; there is a dark brown dot near the middle, a spot of the same color near each angle, a very small triangular whitish spot near the shoulders, and several dark brown longitudinal streaks on the outer hind margin; the hind-wings of the male are brownish or dirty white, with a 
brown spot on the inner hind angle; those of the other sex are dusky brown; the body is light brown, with the thorax rather darker. The wings expand from one inch to one inch and threeeighths.

The second kind grow to a greater size, are longer in coming to their growth, their swarms are more numerous, and consequently they do much more injury than the red-humped kind. Entire branches of the apple-trees are frequently stripped of their leaves by them, and are loaded with these caterpillars in thickly crowded swarms. The eggrs from which they are hatched will be found in patches, of about a hundred together, fastened to the under-side of leaves near the ends of the twigs. Some of them begin to be hatched about the twentieth of July, and new broods make their appearance in succession for the space of a month or more. At first they eat only the under-side and pulpy part of the leaves, leaving the upper-side and veins untouched; but afterwards they consume the whole of the leaves except their stems. These caterpillars are sparingly covered with soft whitish hairs; the young ones are brown, and striped with white; but as they grow older, their colors become darker every time they cast their skins. They come to their full size in about five weeks or a little more, and then measure from an inch and three quarters to two inches and a quarter in extent. The head is large, and of a black color; the body is nearly cylindrical, with a spot on the top of the first ring and the legs dull orange-yellow, a black stripe along the top of the back, and three of the same color alternating with four yellow stripes on each side. The posture of these caterpillars, when at rest, is viry odd; both extremities are raised, the body being bent, and resting only on the four intermediate pairs of legs. If touched or otherwise disturbed, they throw up their heads and tails with a jerk, at the same time bending the body semicircularly till the two extremities almost meet over the back. They all eat together, and, after they have done, arrange themselves side by side along the twigs and branches which they have stripped. Beginning at the ends of the branches they eat all the leaves successively from thence towards the trunk, and if one branch does not afford food enoigh they betake themselves to another. When ready to transform, all the individuals of the same brood quit the tree at once, descending by night, and burrow into the ground to the depth of three or four inches, and, within twenty-four hours afterwards, cast their caterpillar-skins, and become chrysalids without making cocoons. They 
remain in the ground in this state all winter, and are changed to moths and come out between the middle and end of July. These moths belong to the genus Pygcera, so named because the caterpillar sits with its tail raised up. The antennæ are rather long, those of the males fringed beneath, in a double row, with very short hairs nearly to the tips, which, however, as well as the whole of the stalk of the antennæ in the other sex, are bare; the thorax is generally marked with a large dark-colored spot, the hairs of which can be raised up so as to form a ridge or kind of crest; the hinder margin of the fore-wings is slightly notched ; and the forelegs are stretched out before the body in repose. Our Pygoera was named, by Drury, ministra, the attendant or servant. It is of a light brown color; the head and a large square spot on the thorax are dark chestnut-brown; on the fore-wing's are four or five transverse lines, one or two spots near the middle, and a short oblique line near the tip, all of which, with the outer hind margin, are dark chestnut-brown. One and sometimes both of the dark-brown spots are wanting on the fore-wings in the males, and the females, which are larger than the other sex, frequently have five instead of four transverse brown lines. It expands from one inch and three quarters to two inches and a half.

There are seen on the oak, the birch, the black walnut, and the hickory trees, swarms of caterpillars slightly differing in color from each other and from those that live on the apple and cherry trees; they are more hairy than the latter, but their postures and habits appear to be the saine. They are probably only varieties of the ministra, arising from the difference of food.

Corn Caterpillar.-Indian corn often suffers severely from the depredations of one of the genus Nonagrians, known to our farmers by the name of the spindle-worm. This insect receives its common name from its destroying the spindle of the Indian corn; but its ravages generally begin while the corn-stalk is young, and before the spindle rises much above the tuft of leaves in which it is embosomed. The mischief is discovered by the withering of the leaves, and, when these are taken hold of, they may often be drawn out with the included spindle. On examining the corn, a small hole may be seen in the side of the leafy stalk, near the ground, penetrating into the soft centre of the stalk, which, when cut open, will be found to be perforated, both upwards and downwards, by a slender worm-like caterpillar, whose excrementitious casting's surround the orifice of the hole. This caterpillar grows to the length of an 
inch, or more, and to the thickness of a goose-quill. It is smooth, and apparently naked, yellowish, with the head, the top of the first and of the last rings black, and with a band across each of the other rings, consisting of small, smooth, siightly elevated, shining black dots, arranged in a double row. The chrysalis, which is lodged in the burrow formed by the spindle-worm, is slender, but not quite so long in proportion to its thickness as are those of most of the Nonagrians. It is shining mahogany-brown, with the anterior edges of four of the rings of the back roughened with little points, and four short spines or hooks, turned upwards, on the hinder extremity of the body. The fore-wings are rust-red; they are mottled with gray, almost in bands, uniting with the ordinary spots, which are also gray and indistinct; there is an irregular tawny spot near the tip, and on the veins there are a few black dots. The hind-wings are yellowish gray, with a central dusky spot, behind which are two faint, dusky bands. The head and thorax are rust-red, with an elevated tawny tuft on each. The abdomen is pale brown, with a row of tawny tufts on the back. The wings expand nearly one inch and a half.

In order to check the ravages of these insects they must be destroyed while in the caterpillar state. As soon as our corn-fields begin to show, by the withering of the leaves, the usual signs that the enemy is at work in the stalks, the spindle-worms should be sought for and killed; for, if allowed to remain undisturbed until they turn to moths, they will make their escape, and we shall not be able to prevent them from laying their eggs for another brood of these pestilent insects.

Cut Woris.-Numerous complaints have been made of the ravages of cut-worms among corn, wheat, grass, and other vegetables, in various parts of the country. These insects and their history are not yet known to some of the very persons who are said to have suffered from their depredations. Various cut-worms, or more properly subterranean caterpillars, wire-worms and grubworms, or the young of May-beetles, are often confounded together or mistaken for each other; sometimes their names are interchanged, and sometimes the same name is given to each and all of these different animals. Hence the remedies that are successful in some instances are entirely useless in others. The name of cutworm seems originally to have been given to certain caterpillars that live in the ground about the roots of plants, but come up in the night, and cut off and devour the tender stems and lower leaves 

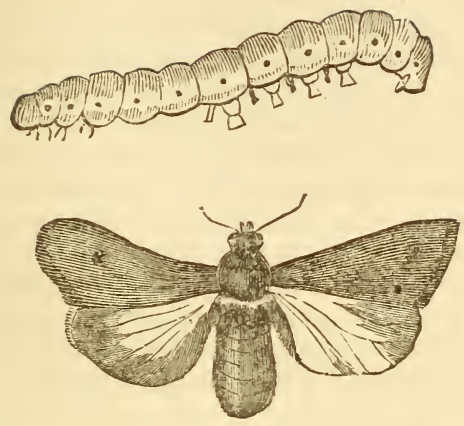

THE CUT WORM.

of young cabbages, beans, corn, and other herbaceous plants. These subterranean caterpillars are finally transformed to moths belonging to a group which may be called Agrotidians (AGROTIDID $x$ ), from a word signifying rustic, or pertaining to the fields. Some of these rustic moths fly by day, and may be found in the fields, especially in the autumn, sucking the honey of flowers; others are on the wing only at night, and during the day lie concealed in chinks of walls and other dark places. Their wings are nearly horizontal when closed, the upper pair completely covering the lower wings, and often overlapping a little on their inner edres, thus favoring these insects in their attempts to obtain shelter and concealment. The thorax is slightly convex, but smooth or not crested. The antennæ of the males are generally beset with two rows of short points, like fine teeth, on the under-side, nearly to the tips. The fore-legs are often quite spiny. Most of these moths come forth in July and August, and soon afterwards lay their eggs in the ground, in plowed fields, gardens, and meadows. In Europe it is found that the eggs are hatched early in the autumn, at which time the little subterranean caterpillars live chiefly on the roots and tender sprouts of herbaceous plants. On the approach of winter they descend deeper into the ground, and, curling themselves up, remain in a torpid state till the following spring, when they ascend towards the suriace, and renew their devastations. The caterpillars of the Agrotidians are smooth, shining, naked, and dark-colored, with longitudinal pale and blackish stripes, and a few black dots on each 
ring; some of them also have a shining, horny, black spot, on the top of the first ring. They are of a cylindrical form, tapering a little at each end, rather thick in proportion to their length, and are provided with sixteen leg's. They are changed to chrysalids in the ground, without previously making silken cocoons.

It is chiefly during the months of June and July that they are found to be most destructive. Whole grain-fields are sometimes laid waste by them. Cabbage-plants, till they are grown to a considerable size, are very apt to be cut off and destroyed by them. Potato-vines, beans, beets, and various other culinary plants suffer in the same way. The products of our flower-gardens are not spared ; asters, balsams, pinks, and many other kinds of flowers are often shorn of their leaves and of their central buds, by these concealed spoilers.

There are several species of Agrotis, the larvæ of which are injurious to culinary plants; but the chief culprit is the same as that which is destructive to young corn. The corn-cut worms make their appearance in great numbers at irregular periods, and confine themselves in their devastations to no particular vegetables, all that are succulent being relished by these indiscriminate devourers; but, if their choice is not limited, they prefer corn-plants when not more than a few inches above the earth, early sown buckwheat, young pumpkin plants, young beans, cabbage-plants, and many other field and garden regetables. When first disclosed from the eggs they subsist on the various grasses. They descend in the ground on the approach of severe frosts, and reappear in the spring about half grown. They seek their food in the night or in cloudy weather, and retire before sunrise into the ground, or beneath stones or any substance which can shelter them from the rays of the sun; here they remain coiled up during the day, except while devouring the food which they generally drag into their places of concealment. Their transformation to pupæ occurs at different periods, sometimes earlier, sometimes later, according to the forwardness of the season, but usually not much later than the middle of July. The moths, as well as the larvæ, vary much in the depth of their color, from a pale ash to a deep or obscure brown. The ordinary spots of the upper wings of the moth are always connected by a blackish line; where the color is of the deepest shade these spots are scarcely visible, but when the color is lighter they are very obvious. This moth is very abundant in the New England States, from the middle of June till the middle or end of August. The fore-wings are 
generally of a dark ash-color, with only a very faint trace of the double transverse wavy bands that are found in most species of Agrotis; the two ordinary spots are small and narrow, the anterior spot being oblong oval, and connected with the oblique kidneyshaped spot, by a longitudinal black line. The lind wings are dirty brownish white, somewhat darker behind. The head, the collar, and the abdomen are chestnut-colored. It expands one inch and three quarters. The wings, when shut, overlap on their imner edges, and cover the top of the back so flatly and closely that these moths can get into very narrow crevices. During the day they lie hidden under the bark of trees, in the chinks of fences, and even under the loose clapboards of buildings. When the blinds of our houses are opened in the morning, a little swarm of these insects, which had crept behind them for concealment, is sometimes exposed, and suddenly aroused from their daily slumber.

Among the various remedies that have been proposed for preventing the ravages of cut-worms in wheat and corn-fields, may be mentioned the soaking of grain, before planting, in copperas-water and other solutions supposed to be disagreeable to the insects; rolling the seed in lime or ashes; and mixing salt with the manure. These may prevent wire-worms and some insects from destroying the seed; but cut-worms prey only on the sprouts and young stalks, and do not eat the seeds. Such stimulating applications may be of some benefit, by promoting a more rapid and vigorous growth of the grain, by which means the sprouts will the sooner become so strong and rank as to resist or escape the attacks of the young cut-worms. Fall-plowing of sward-lands, which are intended to be sown with wheat or planted with corn the year following, will turn up and expose the insects to the inclemency of winter, whereby many of them will be killed, and will also bring them within reach of insect-eating birds. But this seems to be a doubtful remedy, against which many objections have been urged. The most effectual, and not a laborious remedy, even in field-culture, is to go round every morning, and open the earth at the foot of the plant, and you will never fail to find the worm at the root, within four inches. Kill him, and you will save not only the other plants of your field, but, probably, many thousands in future years.

Plem Weevil or Curculio.- It is now well known that the falling of umripe plums, apricots, peaches and cherries, is caused by little whitish grubs, which bore into these fruits. The loss of fruit, occasioned by insects of this kind, is frequently very great; and, 
in some of our gardens and orchards, the crop of plums is often entirely ruined by the depredations of grubs, which are the larvæ or young of a small beetle called the Nenuphar or plum-weevil, or Curculio. These beetles are found as early as the thirtieth of March, and as late as the tenth of June, and at various intermediate times, according with the forwardness or backwardness of vegetation in the spring, and have frequently been caught flying in the middle of the day. They are from three twentieths to one fifth of an inch long, exclusive of the curved snout, which is rather longer than the thorax, and is bent under the breast, between the forelegs, when at rest. Their color is a dark brown, variegated with spots of white, ochre-yellow, and black. The thorax is uneven; the wing-covers have several short ridges upon them, those on the middle of the back forming two considerable humps, of a black color, behind which there is a wide band of ochre-yellow and white. Each of the thighs has two little teeth on the under-side. They begin to sting the plums as soon as the fruit is set, and, as some say, continue their operations till the first of August. After making a suitable puncture with their snouts, they lay one egg in each plum thus stung, and go over the fruit on the tree in this way till their store is exhausted; so that, where these beetles abound, not a plum will escape being punctured. The irritation arising from these punctures, and from the gnawings of the grubs after they are hatched, causes the young fruit to become gummy, diseased, and finally to drop before it is ripe. Meanwhile the grub comes to its growth, and, immediately after the fruit falls, burrows into the ground. This may occur at various times between the middle of June and of August; and, in the space of a little more than three weeks afterwards, the insect completes its transformations, and comes out of the ground in the beetle form.

This same weevil attacks all our common stone-fruits, such as plums, peaches, nectarines, apricots, cherries and apples; and it is not at all improbable that the transformations of some of the grubs may be-retarded till the winter has passed, analogous cases being of frequent occurrence. The plum, still more than the cherry tree, is subject to a disease of the small limbs, which shows itself in the form of large irregular warts, of a black color, as if charred. Grubs, apparently the same as those that are found in plums, have often been detected in these warts, which are now generally supposed to be produced by the punctures of the beetles, and the residence of the grubs. The seat of the disease is in the bark. The sap is di- 
verted from its regular course, and is absorbed entirely by the bark, which is very much increased in thickness; the cuticle bursts, the swelling becomes irregular, and is formed into black lumps, with a cracked, uneven, granulated surface. The wood, besides being deprived of its nutriment, is very much compressed, and the branch above the tumor perishes.

The final transformation of the grubs, living in the fruit, appears to take place at various times during the latter part of summer and the beginning of autumn, when the weevil, finding no young fruit, is probably obliged to lay its eggs in the small branches. The larvæ or grubs from these eggs live in the branches during the winter, and are not perfected till near the last of the following June. Should the fall of the fruit occur late in the autumn, the development of the beetles will be retarded till the next spring; and this is supposed to be the origin of the brood which stings the fruit.

The following, among other remedies that have been suggested, may be found useful in checking the ravages of the plum-weevil. Let the trees be briskly shaken or suddenly jarred every morning: and evening during the time that the insects appear in the beetle form, and are engaged in laying their eggs. When thus disturbe 1 they contract their legs and fall; and, as they do not immediately attempt to fly or crawl away, they may be caught in a sheet spread under the tree, from which they should be gathered into a large wide-mouthed bottle or other tight ressel, and be thrown into the fire. All the fallen wormy plums should be immediately gathered, and, after they are boiled or steamed, to kill the enclosed grubs, they may be given as food to swine. The diseased excrescences should be cut out and burned every year before the last of June. The moose plum-tree (Prunus Americana), seems to escape the attacks of insects, for no warts are found upon it, even when growing in the immediate vicinity of diseased foreign trees. It would, therefore, be the best of stocks for budding or engrafting upon. It can easily be raised from the stone, and grows rapidly, but does not attain a great size.

This plum-weevil, an insect unknown in Europe, when arrived at maturity, is a little, rough, dark brown or blackish beetle, looking like a dried bud, when it is shaken from the trees, which resemblance is increased by its habit of drawing up its legs and bending its snout close to the lower side of its body, and remaining for a time without motion and seemingly lifeless. In stinging the fruit, 
before laying its eggs, it uses its short curved snout, which is armed at the tip with a pair of very small nippers; and by means of this weapon, it makes, in the tender skin of the young plum or apple, a cresient-shaped incision, similar to what would be formed by indenting the fruit with the finger nail. Very rarely is there more than one incision made in the same fruit; and in the wound, the weevil lays only a single egg. The insect hatched from this egg is a little whitish grub, destitute of feet, and very much like a maggot in appearance, except that it has a distinct, rounded, light brown head. It appears, furthermore, that the tumors on plum and on cherry trees are infested not only by these insects, but also by another kind 'of grub, provided with leg's, and occasionally by the wood-eating caterpillars of the AEgeria exitiosa, or peach-tree borer. When the grubs of the plum-weevil are fully grown, they go into the ground, and are there changed to chrysalids of a white color, having the legs and wings free and capable of some motion; and finally they leave the ground in the form of little beetles, exactly like those which had previously stung the fruit. Further observation seems to be wanting before it can be proved that the cankerous warts on plum and cherry trees arise from the irritating punctures of the plum-weevils and of the other insects that occasionally make these warts their places of abode; although it must be allowed that the well-known production of galls by insects on oak-trees and on other plants, would lead us to suppose that those of the plum-tree have a similar origin.

CANKER-WORMS.-The insects called canker-worms are of a kind called Span-worms, or Geometers, and of the group Hybernians. The moths, from which they are produced, belong to the genus Anisopteryx.

It was formerly supposed that the canker-worm moths came out of the ground only in the spring. It is now known that many of them rise in the autumn and in the early part of the winter, and in mild and open winters in every month from October to March. They begin to make their appearance after the first hard frosts in the autumn, usually towards the end of October, and they continue to come forth, in greater or smaller numbers, according to the mildness or severity of the weather after the frosts have begun. Their general time of rising is in the spring, beginning about the middle of March, but sometimes before, and sometimes after this time; and they continue to come forth for the space of about three weeks. It has been observed that there are more females 
than males among those that appear in the autumn and winter, and that the males are most abundant in the spring. The sluggish females instinctively make their way towards the nearest trees, and creep slowly up their trunks. In a few days afterwards they are followed by the winged and active males, which flutter about and accompany them in their ascent, during which the insects pair. Soon after this, the females lay their egg's upon the branches of the trees, placing them on their ends, close together in rows, forming clusters of from sixty to one hundred eggs or more, which is the number usually laid by each female. The eggs are glued to each other, and to the bark, by a grayish varnisb, which is impervious to water; and the clusters are thus securely fastened in the forks of the small branches, or close to the young twig's and buds. Immediately after the insects have thus provided for a succession of their kind, they begin to languish, and soon die. The eggs are usually hatched between the first and the middle of May, or about the time that the red currant is in blossom, and the young leaves of the apple-tree begin to start from the bud and grow. The little canker-worms, upon making their escape from the eggs, gather upon the tender leaves, and, on the occurrence of cold and wet weather, creep for shelter into the bosom of the bud, or into the flowers, when the latter appear. Where these insects prevail, they are most abundant on apple and elm trees; but cherry, plum, and lime trees, and some other cultivated and native trees, as well as many shrubs, often suffer severely from their voracity. The leaves first attacked will be found pierced with small holes; these become larger and more irregular when the canker-worms increase in size; and, at last, the latter eat nearly all the pulpy parts of the leaves, leaving little more than the midrib and veins. A very great difference of color is observable among canker-worms of different ages, and even among those of the same age and size. It is possible that some of these variations may arise from a difference of species; but it is also true that the same species varies much in color. When very young, they have two minute warts on the top of the last ring; and they are generally of a blackish or dusky brown color, with a yellowish stripe on each side of the body; there are two whitish bands across the head; and the belly is also whitish. When fully grown, these individuals become ash-colored on the back, and black on the sides, below which the pale yellowish line remains. Some are found of a dull greenish yellow and others of a clay color, with slender interrupted blackish lines on the sides, and small spots 
of the same color on the back. Some are green, with two white stripes on the back. The head and the feet partake of the general color of the body; the belly is paler. When not eating, they remain stretched out at full length, and resting on their fore and hind legs, beneath the leaves. When fully grown and well fed, they measure nearly or quite one inch in length. They leave off eating when about four weeks old, and begin to quit the trees; some creep down by the trunk, but great numbers let themselves down by their threads from the branches, their instincts prompting them to get to the ground by the most tirect and easiest course. When thus descending, and suspended in great numbers under the limbs of trees overhanging the road, they are often swept off by passing carriages, and are thus conveyed to other places. After reaching the ground, they immediately burrow in the earth, to the depth of from two to six inches, unless prevented by weakness or the nature of the soil. In the latter case, they die, or undergo their transformations on the surface. In the former, they make little carities or cells in the ground, by turning round repeatedly and fastening the loose grains of earth about them with a few silken threads. Within twentyfour hours afterwards, they are changed to chrysalids in their cells. The chrysalis is of a light brown color, and varies in size according to the sex of the insect contained in it; that of the female being the largest, and being destitute of a covering for wings, which is found in the chrysalis of the males. The occurrence of mild weather after a severe frost stimulates some of these insects to burst their chrysalis skins and come forth in the perfected state; and this last transformation, as before stated, may take place in the autumn, or in the course of the winter, as well as in the spring; it is also retarded, in some individuals, for a year or more beyond the usual time. They come out of the ground mostly in the night, when they may be seen struggling through the grass as far as the limbs extend from the body of the trees under which they had been buried. As the females are destitute of wings, they are not able to wander far from the trees upon which they had lived in the caterpillar state. Canker-worms are therefore naturally confined to a very limited space.

In order to protect our trees from the ravages of canker-worms, where these looping spoilers abound, it should be our aim, if possible, to prevent the wingless females from ascending the trees to deposit their eggs. This can be done by the application of tar around the body of the tree, either directly on the bark, as has 
been the most common practice, or, what is better, over a broad belt of clay-mortar, or on strips of old canvass or of strong paper, from six to twelve inches wide, fastened around the trunk with strings. The tar must be applied as early as the first of November, and perhaps in October, and it should be renewed daily as long as the insects continue rising; after which the bands may be removed, and the tar should be entirely scraped from the bark. When all this has been properly and seasonably done, it has proved effectual. The time, labor, and expense attending the use of tar, and the injury that it does to the trees when allowed to run and remain on the bark, have caused many persons to neglect this method, and some to try various modifications of it, and other expedients. Among the modifications may be mentioned a horizontal and close-fitting collar of boards, fastened around the trunk, and smeared beneath with tar; or four boards, nailed together, like a box without top or bottom, around the base of the tree, to receive the tar on the outside. These can be used to protect a few choice trees in a garden, or around a house or a public square, but will be found too expensive to be applied to any great extent. Collars of tin-plate, fastened around the trees, and sloping downwards like an inverted tunnel, have been proposed, upon the supposition that the moths would not be able to creep in an inverted position, beneath the smooth and sloping surface. This method will also prove too expensive for general adoption, even should it be found to answer the purpose. A belt of cotton-wool, which it has been thought would entangle the feet of the insects, and thus keep them from ascending the trees, has not proved an effectual bar to them. Little square or circular troughs of tin or of lead, filled with cheap fish oil, and placed around the trees, three feet or more above the surface of the ground, with a stuffing of cloth, hay, or sea-weed between them and the trunk, have long been used with good success; and the only objections to them are the cost of the troughs, the difficulty of fixing and keeping them in their places, and the injury suffered by the trees when the oil is washed or blown out and falls upon the bark. These troughs ought not to be nailed to the trees, but should be supported by a few wooden wedges driven between them and the trunks. A stuffing of cloth, cotton, or tow, should never be used; sea-weed and fine hay, which will not absorb the oil, are much better. Before the troughs are fastened and filled, the body of the tree should be well coated with clay-paint or white-wash, to absorb the oil that may fall upon it. Care should be taken to renew the 
oil as often as it escapes or becomes filled with the insects. These troughs will be found more economical and less troublesome than the application of tar, and may safely be recommended and employed, if proper attention is given to the precautions above named. Some persons fasten similar troughs, to contain oil, around the outer sides of an open box enclosing the base of the tree, and a projecting ledge is nailed on the edge of the box to shed the rain; by this contrivance, all danger of hurting the tree with the oil is entirely avoided. Let a piece of India rubber be burnt over a gallipot, into which it will gradually drop in the condition of a viscid juice, which state, it appears, it will always retain. Having melted the India rubber, let a piece of cord or worsted be smeared with it, and then 'tied several times round the trunk. The melted substance is so very sticky, that the insects will be prevented, and generally captured, in their attempts to pass over it. It has been suggested that the melted rubber might be applied immediately to the bark without injuring the trees. A little conical mound of sand surrounding the base of the tree is found to be impassable to the moths, so long' as the sand remains dry; but they easily pass over it when the sand is wet, and they come out of the ground in wet, as often as in dry weather.

Some attempts have been made to destroy the canker-worms after they were hatched from the eggs, and were dispersed over the leaves of the trees. It is said that some persons have saved their trees from these insects by freely dusting air-slacked lime over them while the leaves were wot with dew. Showering the trees with mixtures that are found useful to destroy other insects, has been tried by a few, and, although attended with a good deal of trouble and expense, it may be worth our while to apply such remedies upon small and choice trees. A mixture of water and oil-soap (an article to be procured from the manufactories where whale oil is purified,) in the proportion of one pound of the soap to seven gallons of water has been used; this liquor, when thrown on the trees with a garden engine, will destroy the canker-worm and many other insects, without injuring the foliage of the fruit. Jarring or shaking the limbs of the trees will disturb the canker-worms, and cause many of them to spin down, when their threads may be broken off with a pole; and if the troughs around the trees are at the same time replenished with oil, or the tar is again applied, the insects will be caught in their attempts to creep up the trunks. In the same way, also, those that are coming down the trunks to go into 
the ground will be caught and killed. If greater pains were to be taken to destroy the insects in the caterpillar state, their numbers would soon greatly diminish.

Even after they have left the trees, have gone into the ground, and have changed their forms, they are not wholly beyond the reach of means for destroying them. In orchards, in the autumn, root up and kill great numbers of the chrysalids of the cankerworms. Some persons have recommended digging or plowing: under the trees, in the autumn, with the hope of crushing some of the chrysalids by so doing, and of exposing others to perish with the cold of the following winter. If hogs are then allowed to go among the trees, and a few grains of corn are scattered on the loosened soil, these animals will eat many of the chrysalids as well as the corn, and will crush others with their feet.

Apple, elm, and lime-trees, are sometimes injured a good deal by another kind of span-worm, larger than the canker-worm, and very different from it in appearance. It is of a bright yellow color, with ten crinkled black lines along the top of the back; the head is rust-colored; and the belly is paler than the rest of the body. When fully grown, it measures about one inch and a quarter in length. It often rests with the middle of the body curved upwards a little, and sometimes even without the support of its fore-legs. The leaves of the lime seem to be its natural and favorite food, for it may be found on this tree every year; but is seen in considerable abundance, with common canker-worms, on other trees. It is hatched rather later, and does not leave the trees quite so soon as the latter. About or soon after the middle of June it spins down from the trees, goes into the ground, and changes to a chrysalis in a little cell five or six inches below the surface; and from this it comes out in the moth state towards the end of October or during the month of November. More rarely its last transformation is retarded till the spring. The females are wingless and grub-like, with slender thread-shaped antennæ. As soon as they leave the ground they creep up the trees, and lay their egg's in little clusters, here and there on the branches.

As these span-worms appear at the same time as canker-worms, resemble them in their habits, and often live on the same trees, they can be kept in check by such means as are found useful when employed against canker-worms.

The Hop Caterpillar.-The hop-vine is often infested by great numbers of caterpillars called Herminians, of the group Pyralides. 
They eat large holes in the leaves, and thereby sometimes greatly injure the plant. Caterpillars of this kind have also been observed on the hop in Europe, from whence ours may have been introduced; but until specimens from Europe and this country are compared together, in all their states, it will be well to consider the latter as distinct. Our hop-vine caterpillars are false-loopers, bending up the back a little when they creep, because the first pair of prop-legs, found in other caterpillars, is wanting in them. The rings of their bodies are rather prominent, the cross-lines between them being deep. They are of a green color, with two longitudinal white lines along the back, a dark green line in the middle between them, and an indistinct whitish line on each side of the body. The head is green, and very regularly spotted with minute black dots, from each of which arises a very short hair. There are similar dots and hairs arranged in two transverse rows on each of the rings. When disturbed they bend their bodies suddenly and with a jerk, first on one side and then on the other, each time leaping to a considerable distance, so that it is difficult to catch or hold them. They make no webs on the leaves, and do not suspend themselves by silken threads like the Geometers; but they are very active, creep fast, and soon get upon the leaves again after leaping off. When fully grown they are about eight-tenths of an inch long. They then form a thin, imperfect, silky cocoon within a folded leaf, or in some crevice or sheltered spot, and are changed to brownish chrysalids, which present nothing remarkable in their appearance. Three weeks afterwards the moths come forth from these cocoons. There are two broods of these insects in the course of the summer. The caterpillars of the first brood appear in May and June, and are transformed to moths towards the end of June, and during the early part of July. Those of the second brood appear in July and August, and are changed to moths in September. The insects of the second brood are much the most numerous usually, and do much more damage to the hop-vine than the others.

The means for destroying the hop-vine caterpillars are showering or syringing the plants with strong soap-suds, or with a solution of oil-soap in water, in the proportion of two pounds of the soap to fourteen or fifteen gallons of water.

The BeE-Мотн.- The bee-moth belongs to the group of Crambians of the Tineæ. Doubtless it was first brought to this country, with the common hive-bee, from Europe, where it is very abundant, and does much mischief in hives. Very few of the Tinece exceed 
or even equal it in size. In its perfect or adult state it is a winged moth or miller, measuring, from the head to the tip of the clnsed wings, from five eighths to three quarters of an inch in length, and its wings expand from one inch and one tenth to one inch and four tenths. The feelers are two in number; and the tongue is very short, and hardly visible. The fore-wings shut together flatly on the top of the back, slope steeply downwards at the sides, and are turned up at the end, somewhat like the tail of a fowl. The male is of a dusty gray color; his fore-wings are more or less glossed and streaked with purple-brown on the outer edge, they have a few dark brown spots near the inner margin, and they are scalloped or notehed inwardly at the end; his hind-wings are light yellowishgray, with whitish fringes. The female is much larger than the male, and much darker colored; her fore-wings are proportionally longer, not so deeply notched on the outer hind margin, and not so much turned up at the end ; they are more tinged with purplebrown, sprinkled with darker spots; and the hind-wings are dirty or grayish white. There are two broods of these insects in the course of a year. Some winged moths of the first brood begin to appear towards the end of April, or early in May; those of the second brood are most abundant in August; but between these periods, and even later, others come to perfection, and consequently some of them may be found during the greater part of the summer. By day they remain quiet on the sides or in the crevices of the beehouse; but, if disturbed at this time, they open their wings a little, and spring or glide swiftly away, so that it is very difficult to seize or to hold them. In the evening they take wing, when the bees are at rest, and hover around the hive, till, having found the door, they go in and lay their eggs. Those that are prevented by the crowd, or by any other cause, from getting within the hive, lay their eggs on the outside, or on the stand, and the little worm-like caterpillars hatched therefrom easily creep into the hive through the cracks, or gnaw a passage for themselves under the edges of it. These caterpillars, at first, are not thicker than a thread. They have sixteen legs. Their bodies are soft and tender, and of a yellowish white color, sprinkled with a few little brownish dots, from each of which proceeds a short hair; their heads are brown and shelly, and there are two brown spots on the top of the first ring. Weak as they are, and unprovided with any natural means of defence, destined, too, to dwell in the midst of the populous hive, surrounded by watchful and well-armed enemies, at whose expense 
they live, they are taught how to shield themselves against the vengeance of the bees, and pass safely and unseen in every direction through the waxen cells, which they break down and destroy. Beeswax is their only food, and they prefer the old to the new comb, and are always found most numerous in the upper part of the hive, where the oldest honeycomb is lodged. It is not a little wonderful, that these insects should be able to get any nourishment from wax, a substance which other animals cannot digest at all ; but they are created with an appetite for it, and with such extraordinary powers of digestion, that they thrive well upon this kind of food. As soon as they are hatched they begin to spin; and each one makes for itself a tough silken tube, wherein it can easily turn around and move backwards or forwards at pleasure. During the day they remain concealed in their silken tubes; but at night, when the bees cannot see them, they come partly out, and devour the wax within their reach. As they increase in size, they lengthen and enlarge their dwelling's, and cover them on the outside with a coating of grains of wax mixed with their own castings, which resemble gunpowder. Protected by this coating from the stings of the bees, they work their way through the combs, gnaw them to pieces, and fill the hive with their filthy webs; till at last the discouraged bees, whose diligence and skill are of no more use to them in contending with their unseen foes, than their superior size and powerful weapons, are compelled to abandon their perishing brood and their wasted stores, and leave the desolated hive to the sole possession of the miserable spoilers. These caterpillars grow to the length of an inch or a little more, and come to their full size in about three weeks. They then spin their cocoons, which are strong silken pods, of an oblong oval shape, and about one inch in length, and are often clustered together in great numbers in the top of the hive. Some time afterwards, the insects in these cocoons change to chrysalids of a light brown color, rough on the back, and with an elevated dark brown line upon it from one end to the other. When this transformation happens in the autumn, the insects remain without fnrther change till the spring, and then burst open their cocoons, and come forth with wings. Those which become chrysalids in the early part of summer are transformed to winged moths fourteen days afterwards, and immediately pair, lay their egges, and die.

Bees suffer most from the depredations of these insects in hot and dry summers. Strong and healthy swarms, provided with a con- 
stant supply of food near home, more often escape than small and weak ones. When the moth-worms have established themselves in a hive, their presence is made known to us by the little fragments of wax and the black grains seattered by them over the floor. Means should then be taken, without delay, to dislodge the depredators and invigorate the swarm. Köllar states that there is but one sure method of clearing bee-hives of the moth, and this is to look for and destroy the caterpillars or moth-worms and the chrysalids; and he advises that the hives should be examined, for this purpose, once a week, and that all the webs and cocoons, with the insects in them, should be taken out and destroyed. At all events, the examination ought to be made every year, early in September, when the cocoons will be found in greater numbers than at any other time, and should be carefully removed and burned. The winged moths are very fond of sweets; and if shaliow vessels, containing a mixture of honey or sugar, with vinegar and water, are placed near the bee-house in the evening, the moths will get into them and be drowned. In this way great numbers may be caught every night. Several kinds of hives and bee-houses have been contrived and recommended, for the purpose of keeping out the beemoth; but it does not appear that any of them entirely supersede the necessity for the measures above recommended.

GraIN Moths.-The various kinds of destructive moths, found in houses, stores, barns, granaries, breweries, and mills, are mostly very small insects; the largest of them, when arrived at maturity, expanding their wings only about eight tenths of an inch. The ravages of some of these little creatures are too well known to need a particular description. Among them may be mentioned the grainmoth ( $T$. grunella), with some others belonging to a group, which may be called Tineans (Tireades), and the Angoumois grain-moth (Anacampsis cerealella, ) both of which are to be included among the Yponomeutians.

Stored grain is exposed to much injury from the depredations of two little moths, in Europe, and is attacked in the same way, and apparently by the same insects, in this country.

The European grain-moth (Tinea granella), in its perfected state, is a winged insect, between three and four tenths of an inch long from the head to the tip of its wings, and expands six tenths of an inch. It has a whitish tuft on its forehead; its long and narrow wings cover its back like a sloping roof, are a little turned up behind, and are edged with a wide fringe. Its fore-wings are glossy 
like satin, and are marbled with white or gray, light brown, and dark brown or blackish spots, and there is always one dark square spot near the middle of the outer edge. Its hind-wings are blackish. Some of these winged moths appear in May, others in July and August, at which times they lay their eggs; for there are two broods of them in the course of the year. The young from the first laid eggs come to their growth and finish their transformations in six weeks or two months; the others live through the winter, and turn to winged moths in the following spring. The young moth-worms do not burrow into the grain, as has been asserted by some writers, who seem to have confounded them with the Angoumois grain-worms ; but, as soon as they are hatched, they begin to gnaw the grain and cover themselves with the fragments, which they line with a silken web. As they increase in size they fasten together several grains with their webs, so as to make a larger cavity, wherein they live. After a while, becoming uneasy in their confined habitations, they come out, and wander over the grain, spinning their threads as they go, till they have found a suitable place wherein to make their cocoons. Thus, wheat, rye, barley, and oats, all of which they attack, will be found full of lumps of grains cemented together by these grain-worms; and when they are very numerous, the whole surface of the grain in the bin will be covered with a thick crust of webs and of adhering grains. These destructive grain-worms are really soft and naked caterpillars, of a cylindrical shape, tapering a little at each end, and are provided with sixteen legs, the first three pairs of which are conical and jointed, and the others fleshy and wart-like. When fully grown, they measure four or five tenths of an inch in length, and are of a light ochre or buff color, with a reddish head. When about six weeks old they leave the grain, and get into cracks, or around the sides of corn-bins, and each one then makes itself a little oval pod or cocoon, about as large as a grain of wheat. The insects of the first brood, as before said, come out of their cocoons, in the winged form, in July and August, and lay their eggs for another brood: the others remain unchanged in their cocoons, through the winter, and take the chrysalis form in March or April following. Three weeks afterwards, the shining brown chrysalis forces itself part way out of the cocoon, by the help of some little sharp points on its tail, and bursts open at the other end, so as to allow the moth therein confined to come forth.

There is another grain-moth, which, at various times, has been 
found to be more destructive in granaries, in some provinces of France, than the preceding kind. It is the Angoumois moth (Anacampsis? cerealella), an insect evidently belonging to the family of Yponomeutians. The winged moths of this group have only two visible feelers, and these are generally long, slender, and curved over their heads. Their narrow wings most often overlap each other, and cover their backs horizontally when shut. The Angoumois grain-moth probably belongs to the modern genus Anacampsis. In the year 1768, Colonel Landon Carter, of Sabine Hall, Virginia, communicated to the American Philosophical Society at Philadelphia, some interesting "Observations concerning the Fly-weevil that destroys wheat." The Angoumois moth, or Anacampsis cerealella, in its perfected state, is a four-winged insect, about three eighths of an inch long, when its wings are shut. It has a pair of tapering curved feelers, turned over its head. Its upper wings are narrow, of a light brown color, without spots, and have the lustre of satin; they cover the body horizontally above, but droop a little at the sides. The lower wings and the rest of the body are ash-colored. This moth lays its egg's, which vary in number from sixty to ninety, in clusters, on the ears of wheat, rye, and barley, most often while these plants are growing in the field, and the ears are young and tender; sometimes also on stored grain in the autumn. Hence it appears that they breed twice a year; the insects from the eggs laid in the early part of summer, coming to perfection and providing for another brood of moth-worms in the autumn. The little worm-like caterpillars, as soon as they are hatched, disperse, and each one selects a single grain, into which it burrows immediately at the most tender part, and remains concealed therein after the grain is harvested. It devours the mealy substance within the hull ; and this destruction goes on so secretly, that it can only be detected by the softness of the grain or the loss of its weight. When fully grown this caterpillar is not more than one fifth of an inch long: It is of a white color, with a brownish head; and it has six small jointed legs, and ten extremely small wart-like proplegs. Duhamel has represented it as having two little horns just behind the head, and two short bristles at the end of its tapering body. Having eaten out the heart of the grain, which is just enough for all its wants, it spins a silken web or curtain to divide the hollow, lengthwise, into two unequal parts, the smaller containing the rejected fragments of its food, and the larger cavity serving instead of a cocoon, wherein the insect undergoes its transformations. Before turning to a chry- 
salis it gnaws a small hole nearly or quite through the hull, and sometimes also through the chaffy covering of the grain, through which it can make its escape easily when it becomes a winged moth. The insects of the first, or summer brood, come to maturity in about three weeks, remain but a short time in the chrysalis state, and turn to winged moths in the autumn, and at this time may be found, in the evening, in great numbers, laying their eggs on the grain stored in barns and granaries. The moth-worins of the second brood remain in the grain through the winter, and do not change to winged insects till the following summer, when they come out, fly into the fields in the night, and lay their eggs on the young ear's of the growing grain. When damaged grain is sown it comes up very thin; the infected kernels never sprout, but the insects lodged in them remain alive, finish their transformations in the field, and in due time come out of the ground in the winged form.

It has been proved by experience that the ravages of the two kinds of grain-moths, whose history has been now given, can be effectually checked by drying the damaged grain in an oven or kiln; and that a heat of one hundred and sixty-seven degrees, by Fahrenheit's thermometer, continued during twelve hours, will kill the insects in all their forms. Indeed the heat may be reduced to one hundred and four degrees, with the same effect, but the grain must then be exposed to it for the space of two days. The other means, that have been employed for the preservation of grain from these destructive moths, it is unnecessary to describe; they are probably well known to most of our farmers and millers, and are rarely so effectual as the process above mentioned.

Hessiax Fly.-Under the name of Diptera, signifying twowinged, are included all the insects that have only two wings, and are provided with two little knobbed threads in the place of hindwings, and a mouth formed for sucking or lapping. Various kinds of gnats and of flies are therefore the insects belonging to this order. The proboscis or sucker, wherewith they take their food, is placed under the head, and sometimes can be drawn up and concealed, partly or wholly, within the cavity of the mouth.

The young insects, hatched from the eggs of gnats and of flies, are fleshy larvæ, usually of a whitish color, and without leg's. They are commonly called maggots, and sometimes are mistaken for worms. They vary a good deal in their forms, structure, habits, and transformations, so that it is somewhat difficult to give any general description of them. Most insects are hatched from egg's 
which are laid by the mother on the substances that are to serve for the food of her young.

The far-famed Hessian fly and the wheat-fly of Europe, and of this country, are small gnats or midges, and belong to the family called CECidomiad E, or gall-gnats. The insects of this family are very numerous, and most of them, in the maggot state, live in galls or unnatural enlargements of the stems, leaves, and buds of plants, caused by the punctures of the winged insects in laying their eggs. The Hessian fly, wheat-fly, and some others differ from the majority in not producing such alterations in plants. The proboscis of these insects is very short, and does not contain the piercing bristles found in the long proboscis of the biting gnats and musquitos. Their antennæ are long, composed of many little, bead-like joints, which are larger in the males than in the other sex; and each joint is surrounded with short hairs. Their eyes are kidney-shaped. Their legs are rather long and very slender. Their wings have only two, three, or four veins in them, and are fringed with little hairs around the edges; when not in use, they are generally carried flat on the back. The hind-body of the females often ends with a retractile, conical tube, wherewith they deposit their eggs. Their young are little, footless maggots, tapering at each end, and generally of a deep yellow or orange color. They live on the juices of plants, and undergo their transformations either in these plants, or in the ground.

The Hessian fly was scientifically described by Mr. Say, in 1817, under the name of Cecidomyia destructor. It obtained its common name from a supposition that it was brought to this country, in some straw, by the Hessian troops under the command of Sir William Howe in the war of the Revolution.

The head and thorax of this fly are black. The hind-body is tawny, and covered with fine grayish hairs. The wings are blackish, but are more or less tinged with yellow at the base, where also they are very narrow; they are fringed with short hairs, and are rounded at the end. The body measures about one tenth of an inch in length, and the wings expand one quarter of an inch, or more. It is a true Cecidomyia, differing from Lasioptera in the shortness of the first joint of its feet, and in the greater length of its antennæ, the bead-like swellings whereof are also most distant from each other. Two broods or generations are brought to maturity in the course of a year, and the flies appear in the spring and autumn, but rather earlier in the Southern and Middle States than 
in New England. The transformations of some in each brood appear to be retarded beyond the usual time, as is found to be the case with many other insects; so that the life of these individuals, from the egg to the winged state, extends to a year or more in length, whereby the continuation of the species in after years is made more sure. It has frequently been asserted that the flies lay their eggs on the grain in the ear; but whether this be true or not, it is certain that they do lay their eggs on the young plants, and long before the grain is ripe; for many persons liave witnessed and testified to this fact. In the New England States and New York, winter wheat is usually sown about the first of September. Towards the end of this month, and in October, when the grain has sprouted, and begins to show a leaf or two, the flies appear in the fields, and, having paired, begin to lay their egg's, in which business they are occupied for several weeks. The Hessian fly lays her eggs in the small creases of the young leaves of the wheat. If the weather be warm, the eggs commonly hatch in four days after they are laid. The maggots, when they first come out of the shells, are of a pale red color. Forthwith they crawl down the leaf, and work their way between it and the main stalk, passing downwards till they come to a joint, just above which they remain, a little below the surface of the ground, with the head towards the root of the plant. Having thus fixed themselves upon the stalk, they become stationary, and never move from the place till their transformations are completed. They do not eat the stalk, neither do they penetrate within it, as some persons have supposed, but they lie lengthwise upon its surface, covered by the lower part of the leaves, and are nourished wholly by the sap, which they appear to take by suction. They soon lose their reddish color, turn pale, and will be found to be clouded with whitish spots; and through their transparent skins a greenish stripe may be seen in the middle of their bodies. As they increase in size, and grow plump and firm, they become imbedded in the side of the stem, by the pressure of their bodies upon the growing plant. One maggot thus placed seldom destroys the plant; but, when two or three are fixed in this manner around the stem, they weaken and impoverish the plant, and cause it to fall down, or to wither and die. They usually come to their full size in five or six weeks, and then measure about three twentieths of an inch in length. Their skin now gradually hardens, becomes brownish, and soon changes to a bright chestnut color. This change usually happens about the first of December, when the 
insect may be said to enter on the pupa state, for after this time it takes no more nourishment. The brown and leathery skin, within which the maggot has changed to a pupa or chrysalis, is long eggshaped, smooth, and marked with eleven transverse lines, and measures one eighth of an inch in length. In this form it has been commonly likened to a flax-seed. The maggots of the Hessian fly do not cast off their skins in order to become pupx, wherein they differ from the larvæ of most other gnats, and agree with those of common flies; neither do they spin cocoons, as some of the Cecidomyians are supposed to do. 'The pupa gradually cleaves from the dried skin of the larva, and, in the course of two or three weeks, is wholly detached from it. Still inclosed within this skin, which thus becomes a kind of cocoon or shell for the pupa, it remains throughout the winter, safely lodged in its bed on the side of the stem, near the root of the plant, and protected from the cold by the dead leaves. Towards the end of April and in the forepart of May, or as soon as the weather becomes warm enough in the spring, the insects are transformed to flies. They make their escape from their winter quarters by breaking through one end of their shells and the remains of the leaves around them. Very soon after the flies come forth in the spring, they are prepared to lay their eggs on the leaves of the wheat sown in the autumn before, and also on the spring-sown wheat, that begins, at this time, to appear above the surface of the ground. They continue to come forth and lay their eggs for the space of three weeks, after which they entirely disappear from the fields. The maggots hatched from these eggs, pass along the stems of the wheat, nearly to the roots, become stationary, and turn to pupæe in June and July. In this state they are found at the time of harvest, and, when the grain is gathered, they remain in the stubble in the fields. To this, however, as $\mathrm{Mr}$. Havens remarks, there are some exceptions ; for a few of the insects do not pass so far down the side of the stems as to be out of the way of the sickle when the grain is reaped, and consequently will be gathered and carried away with the straw. Most of them are transformed to flies in the autumn, but others remain unchanged in the stubble or straw till the next spring. In the winged state, these flies, or more properly gnats, are very active, and, though evry small and seemingly feeble, are able to fly to a considerable distance in search of fields of young grain. Their principal migrations take place in August and September in the Middle States, where they undergo their final transformations earlier than in New 
England. There, too, they sometimes take wing in immense swarms, and, being probably aided by the wind, are not stopped in their course either by mountains or rivers. On their first appearance in Pemnsylvania they were seen to pass the Delaware like a cloud. Being attracted by light, they have been known, during the wheat harrest, to enter louses in the evening in such numbers as seriously to annoy the inhabitants.

The old discussion, concerning the place where the Hessian fly lars her eggs, has lately been revived by Miss Margaretta H. Morris, of Germantown, Pennsylvania. Miss Morris believes she has established that the ovum (egg) of this destructive insect is deposited in the seed of the wheat, and not in the stalk or culm. She has watched the progress of the animal since June, 1836, and has satisfied herself that she has frequently seen the larva within the seed. She has also detected the larva, at various stages of its progress, from the seed to between the body of the stalk and the sheath of the leares. According to her observations, the recently hatched. larva penetrates to the centre of the straw, where it may be found of a pale greenish white semitransparent appearance, in form somewhat resembling a silk worm. From one to six of these have been found at various heights from the seed to the third joint. From the foregoing, we are led to infer, that the egg, being sowed with the grain, is hatched in the ground, and that the maggot afterwards mounts from the seed through the middle of the stem, and, having: reached a proper height, escapes from the hollow of the straw to the outside, where it takes the pupa or flax-seed state. The fact that the Hessian fly does ordinarily lay her egg's on the young: leaves of wheat, barley, and rye, both in the spring and in the autumn, is too well authenticated to admit of any doubt. If, therefore, the observations of Miss Morris are found to be equally correct, they will serve to show, still more than the foregoing history, how variable and extraordinary is the economy of this insect, and how great are the resources wherewith it is provided for the continuation of its kind.

Various means have been recommended for preventing or lessening the ravages of the Hessian fly ; but they have hitherto failed, either because they have not been adapted to the end in view, or because they have not been universally adopted; and it appears doubtful whether any of them will ever entirely exterminate the insect. Miss Morris advises obtaining "fresh seed from localities in which the fly has not made its appearance," and that "by this 
means the crop of the following year will be uninjured; but in order to aroid the introduction of straggling insects of the kind from adjacent fields, it is requisite that a whole neighborhood should persevere in this precaution for two or more years in succession." The stouter varieties of wheat ought alwars to be chosen, and the land should be kept in good condition. If fall wheat is sown late, some of the eggs will be avoided, but risk of winter-killing the plants will be incurred. If cattle are permitted to graze the wheat fields during the fall, they will devour many of the eggs. A large number of the pupæ may be destroyed by burning the wheat-stubble immediately after harvest, and then plowing and harrowing the land. This method will undoubtedly do much good. As the Hessian fly also lays its eggs, to some extent, on rye and barley, these crops should be treated in a similar manner. It is found that luxuriant crops more often escape injury than those that are thin and light. Steeping the grain and rolling it in plaster or lime tends to promote a rapid and vigorous growth, and will therefore prove beneficial. Sowing the fields with wood ashes, in the proportion of two bushels to an acre, in the autumn, and again in the first and last weeks in April, and as late in the month of May as the sower can pass over the wheat without injury to it, has been found useful. Farorable reports have been made upon the practice of allowing sheep to feed off the crop late in the autumn, and it has also been recommended to turn them into the fields again in the spring; in order to retard the growth of the plant till after the fly has disappeared. Too much cannot be said in favor of a judicious management of the soil, feeding off the crop by cattle in the autumn, and burning the stubble after harvest; a proper and general attention to which will materially lessen the evils arising from the dep. redations of this noxious insect. 


\section{SAXTON'S RURAL HAND BOOKS.}

\section{SAXTON'S HAND BOOKS OF RURAL AND DOMESTIC ECONOMY.}

All Arranged and Adapted to the Use of American Farmers.

Price 25 Cents each.

Hogs ;

Their Origin and Varieties; Management, with a view to Profit, and Treatment under Disease; also Plain Directions relative to the most approved methods of preserving their flesh. By H. D. Richardson, author of "The Hive and the Honey Bee," \&c., \&c. With Illustrations-12mo.

The Hive and Honey Bee;

With plain directions for obtaining a considerable Annual Income from this branch of Rural Economy; also an account of the Diseases of Bees, and their Remedies, and Remarks as to their Enemies, and the best mode of protecting the Hives from their attacks. By H.D. Richardson. With Illustrations. Domestic Fowls ;

Their Natural History, Breeding, Rearing and General Management. By H. D. Richardson, author of "The Natural History of the Fossil Deer," \&c. With Illustrations.

\section{The Horse ;}

Their Origin and Varieties-with Plain Directions as to the Breeding, Rearing and General Management, with Instructions as to the Treatment of Disease. Handsomely Illustrated-12mo. By H. D. Richardson.

\section{The Rose ;}

The American Rose Culturist-being a Practical Treatise on the Propagation, Cultivation and Management in all Seasons, etc. With full directions for the Treatment of the Dahlia.

The Pests of the Farm;

With Instructions for their Extirpation; being a Manual of Plain Directions for the certain Destruction of every description of Vermin. With numerous Illustrations on Wood.

\section{An Essay on Manures ;}

Submitted to the Trustees of the Massachusetts Society for Promoting Agriculture, for their Premium. By Samuel H. Uana.

The American Bird Fancier ;

Considered with Reference to the Breeding, Rearing, Feeding, Management and Peculiarities of Cage and House Birds. Illustrated with Engravings. By D. Jay Browne.

Chemistry Made Easy:

For the Use of Farmers. By J. Topham.

Elements of Agriculture;

Translated from the French, and Adapted to the Use of American Farmers. By F. G. Skinner.

Milburn on the Cow; edited by Richardson.

With Illustrations.

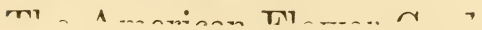




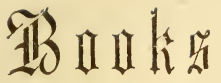

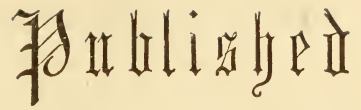 \\ BY

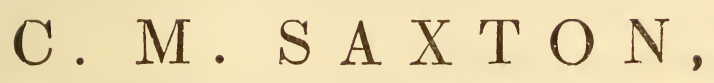 \\ 152 FULTUN STREET, NEW YORK,}

SUITABLE FOR

\section{S CH $00 \mathrm{~L}$, T $0 \mathrm{WN}$, A GRIUULTURAL。}

AND

\section{P २IVATE LIBRARIES.}

\section{'The American Farm Book;}

The Americ.n Farm Book; or, a Compend of American Agriculture, being a Practical Treatise on Scils, Manures, Draining, Irrigation, Grisses, Grain, Roots, Fruits, Cotton Tobacco, Sugar-Cane, Rice, and every staple product of the United States; with tho best methods of Planting, Cultivating, and Preparation for Market. Illustrated by more than 100 engravings. By R. L. Allen. Cloth, $\$ 1$; mail edition, paper, $75 \mathrm{cts}$.

\section{American Poultry Yard;}

The American Poultry Yard; comprising the Origin, History and Description of the different Breeds of Domestic Poultry, with complete directions for their Breeding, Crossing, Rearing, Fattening, and Preparation for Market; including specific directions for Caponizing Fowls, and for the Treatment of the Princ:pal Diseases to which they are subject; drawn from authentic sources and personalobservation. Illustrated with numerous engravings By D. J. Browne. Cloth or sheep, $\$ 1$; mail edition, paper, 75 cts.

\section{The Diseases of Domestic Animals;}

Being a History and Description of the Horse, Mule, Cattle, Sheep. Swine, Poultry, and Farm Dogs, with Directions for their Management, Breeding, Crossing, Rearing, Feeding, and Preparation for a profitable Market; also, their Diseases and Remedies ; together with full Directions for the Management of the Dairy, and the Comparative Ficonomy and Advantages of Working Animals, the Horse, Mule, Oxen, \&c. By R. L. Allen. Cloth or sheep, 75 cts.; mail edition, paper, $50 \mathrm{cts}$.

\section{American Bee Keeper's Manual;}

Being a Practical Treatise on the History and Domestic Economy of the Honey Bee, embracing a full illustration of the whole subject, with the most approved methods of Managing this Insect, through every branch of its Culture, the result of many years' experience. Illustrated with many engravings. By T. B. Miner. Cloth or sheep, $\$ 1$.

\section{The Modern Stair Builder's Guide :}

Deing a Plain, Practical System of Hand Railing, embracing all its necessary Details, and Geometrically Illustrated by Twenty-two Steel Engravings; together with the Uso of the most important Principles of Practical Geometry. By simen De Graff, Archi. tect. $\$ 2$.

\section{Prize Essay on Manures.}

An Essay on Manures, submitted to the Trustees of the Massachnsetts Srniotw fn- $n$ moting Agriculture, for their Premium. By Samuel L. Dar 


\section{American Bird Fancier.}

Considered with reference to the Breeding, Rearing, Feeding, Management, \&c., of Cago and House Birds. 1llustrated with engravings. B.y D. J. Brcwne. Cloth, 50 cts.; mail edition, paper, $25 \mathrm{cts}$.

\section{American Architect.}

Tns American Architect; comprising Original Designs of cheap Cruntry and Village Residences, with Details, Specifications, Plans, and Directions, and an estimate of the Cost of each Design. By John W. Ritch, Architect. Firs and second Series ouarto, bound in 2 vols., sheep, $\$ 6$. Ma:d thition, paper, $\$ \bar{J}$.

\section{Domestic Medicine.}

Gunn's Domestic Medicine ; or, Poor Man's Friend in the Hours of Affliction, Pain, and Sickness. Raymond's new revised edition, improved and enlarged by John C. Gunn. 8vo. Sheep. \$3.

\section{Saxton's American Farmer's Almanac for 1852.}

Per $100, \$ 3$.

\section{Family Kitchen Gardener.}

Containing Plain and Accurate Descriptions of ali the Different Species and Varieties of Culinary Vegetables; with their Botanical, English. French, and German names, alphabeticaliy arranged, and the best mode of cultivating them in the garden, or undes glass; also, Descriptions and Character of the most Select Fruits, their Management. Propagation, \&c. By Robert Buist. author of the American Flower Garden Directory, \&c. cloth or sheep, $75 \mathrm{cts}$; mail edition, paper, $50 \mathrm{cts}$

\section{Practical Agriculture.}

Being a Treatise on the General Relations which Science bears to Agriculture. Delivered before the New York State Agriculturad Society, by James F. W. Johnston, F.R.S.S.S. and F., Professor of Agricultural Chemistry in Durham University, and author of Lectures on Agricultural Chemistry, with Notes and Explanations by an American Farmer. Cloth, $75 \mathrm{cts}$.; mail edition, paper, $50 \mathrm{cts}$.

\section{Elements of Agricultural Chemistry and Geology}

By J. F. W. Johnston, M.A., F.R.S. $50 \mathrm{cts}$.

\section{Youatt and Martin on Cattle:}

Being a Treatise on their Breeds, Management, and Diseases ; comprising a full History of the Various Races; their Origin, Breeding, and Merits; their capacity for Beef and Milk. By W. Youatt and W. C. L. Martin. The whole forming a complete Guide for the Farmer, the Amateur, and the Veterinary Surgeon, with 100 illustrations. Edited by Ambrose Stevens. $\$ 125$.

\section{Youatt on the Horse.}

Youatt on the Structure and Diseases of the Horse, with their Remedies. Also, Practical Rules for Buyers, Breeders, Breakers, Smiths, \&c. Edited by W. C. Spuoner, M R.C.V.S. With an account of the Breeds in the United States, by Henry $S$ Randall. $\$ 125$.

\section{Youatt on Sheep :}

Their Breed, Management. and Diseases, with illustrative engravings; to which are alded Remarks on the Breeds and Management of Sheep in the United States, and on the Culture of Fine Wool in Silesia. By Wm. Youatt. $75 \mathrm{cts}$.

\section{Hoare on the Grape Vine.}

A Practical Treatise on the Cultivation of the Grape Vino on open Walls, with a Descriptive Account of an improved method of Planting and Mlanaging the Rocts of Grapo Vines. By Clement Hoare. With an Appasdix on the Cultivation of the same in the United States. $50 \mathrm{cts}$. 


\section{Books Published by C. M. Saxton.}

\section{The American Agriculturist:}

Being a Collection of Original Articles on the Various Subjects connected with the Farm, in ten vols. 8vo., containing nearly four thousand pages. \$i0.

\section{Johnston's Agricultural Chemistry.}

Lectures on the Application of Chemistry and Geology to Agriculture. New edition, with an Appendix. $\$ 125$.

\section{Stephens' Book of the Farm.}

A Complete Guide to the Farmer, Steward, Plowman, Cattleman, Shepherd, FieldWorker, and Dairy MIaid. By Henry Stephens. With Four Hundred and Fifty Illustrations; to which are added Explanatory Notes, Remarks. \&ce, by J. S. Skinner. Really one of the best books for a Farmer to possess. Cloth, $\$ \$$; leather, $\$ 150$.

\section{'The Complete Farmer and American Gardener,}

Rural Economist, and New American Gardener, containing a Compendious Epitome of the most Important Branches of Agricultural and Rural Economy; with Pracical Directions or the Cultivation of Fruits and Vegetahles ; including Landscape and Orna mental Gardening. By Thomas G. Fessenden. "y ruls. in one. \$1 25.

Chemistry Made Easy,

For the Use of Farmers. Ey J. Topham, M.A. $25 \mathrm{cts}$.

\section{Brandy and Salt,}

A Remedy for various Internal as well as External Diseases, Inflammation and I ocal Injuries. By Rev. Samuel Fenton. $12 \frac{1}{2} \mathrm{cts}$.

\section{Southern Agriculture.}

Comprising Essays on the Cultivation of Corn, Hemp, Tobacco, Wheat, \&c. $\$ 1$.

\section{The Cottage and Farm Bee Keeper:}

A Practical Work, by a Courtry Curate. $50 \mathrm{cts}$.

\section{A Book for Every Boy in the Country.}

Elements of Agriculture. Translated from the French, and adapted to General Use, by F. G. Skinner. $25 \mathrm{cts}$.

\section{Rural Architecture;}

Comprising Farm Houses, Cottages, Carriage Houses, Sheep and Dove Cotes, Pigeries, Barns, \&c. \&c. By Lewis F. Allen. \$1 25.

\section{The American Muck Book.}

The American Nuck Bool:; treating of the Nature, Properties, Sources, History, and Operations of all the principal Fertilizers and Manures in Common Use, with Specific Directions for their Preservation, and Application to the Soil and to Crrps; drawn from Authentic Sources. Actual Experience, and Perssnal Observation, as Combined with the leading Principles of Practical and scientific Agriculture. By J. D. Browne. \$1.

Youatt on the Pig.

A Trextise on the Breeds, Management, and Medical Treatment of Swine ; with direc. t:on for Sslting Pork, Curing Bacon and Hams. By Wm. Youatt, R.S. Illustrated vitt engravings drawn from life. $60 \mathrm{cts}$.

Youatt on the Dog.

By Wm. Youatt, Splendidly illustrated. Edited, with Aiditions, by E, J. Lewis, M.D $\$ 150$.

The Poultry Book,

By $\therefore$ : hn C. Bennett, M.D. 84 cts. 
The American Poulterer's Companion,

With illustrations. By C N. Bement. \$1.

American Poultry Book.

By Micajah Cock. 33 cts,

The Rose Culturist.

A Practical Treatise on its Cultivation and Nanagement. $33 \mathrm{cts}$.

A Practical Treatise on Honey Bees,

Their Management, \&c. By Edward Townley. 50 cts.

The American Fruit Book.

By S. W. Cole, $50 \mathrm{cts}$.

The American Veterinarian.

By S. W. Cole. 50 cts.

The Gardener's Text Book.

By Peter Adam Schenck. 50 cts.

The American Gardener.

By William Cobbett. $50 \mathrm{cts}$.

The Farmer's Land Measurer.

By James Pedder. $50 \mathrm{cts}$.

New England Fruit Book.

By John M. Ives. 56 cts.

Practical Treatise on Fruits,

Adapted to New England Culture. By George Faques. $50 \mathrm{cts}$

Farmer and Emigrant's Hand Book.

A Guide to Clearing the Forest and Prairie Land, \&c., \&c. By Josiah T. Marshall, 75 cts.

Farmer's Barn Book.

By Youatt, Clater, Skinner and Mills. \$1 25.

Hind's Farriery and Stud Book.

Edited by J. S. Skinner. \$1.

Mason's Farrier and Stud Book.

E'dited by J. S. Skinner. $\$ 125$.

Stewart's Stable Economy.

A Treatise on the Management of Horses. Edited by A. B. Allen. \$1.

Sugar Planter's Manual.

By W. S. Evar.s, MI D. \$1 25.

Treatise on Hothouses and Ventilation. 


\section{Books for Sale by C. M. Saxton.}

Ornamental and Domestic Poultry.

By Rev. Edmund Saul Dixon, A.M. With Large Addiuons by J. J. Kerr, M.D. With illustrations. \$1.

\section{Canfield on Sheep,}

Their Breeds, Management, Structure, and Diseases. Witt: [llustrative Engravings and an Appendix. Edited by H. J. Canfield. $\$ 1$.

\section{Book of Flowers,}

In which are described the various Hardy Hervaceous Jerennials, Annuals, Shrubbr Plants and Evergreen Trees desirable for Ornamental Purposes. By Jos. Breck. 75 cts.

Experimental Researches on the Fnod of Animals, The Fattening of Cattle, and Remarks on the Food of MIan. By Robert Dandas Thompson, M.D. $75 \mathrm{cts}$.

\section{The American Flower Garden Companion,}

Revised and enlarged. By Edward Sayres, $75 \mathrm{cts}$,

The Farmer's Treasure.

A Treatise on the Natnre and Value of Manures, and Productive Farming. By F. Faulkner and Joseph A. Smith. $75 \mathrm{cts}$.

The Practical Farrier.

By Richard Mason. 75 cts.

The American Farrier.

By Barnum. $75 \mathrm{cts}$.

Principles of Practical Gardening.

By Ġeo. W. Johnston, Esq. \$1 25.

The American Fruit Garden Companion.

A Treatise on the Propagation and Culture of Fruit. By S. Sayres. $38 \mathrm{cts}$

Spooner on the Grape.

The Cultivation of American Grape Vines, and making of Wine. By Alden Spooner $38 \mathrm{cts}$.

The Young Gardener's Assistarit.

By Thomas bridgeman. \$1 50.

The Florist's Guide.

By Thos. Bridgeman. 50 cts.

The Kitchen Gardener's Instructor.

By Bridgeman. 50 crs.

The Fruit Cultivator's Manual.

The Horse,

By Bridgeman. $50 \mathrm{cts}$.

Its Habit, Diseases and Managerr $3 n t$, in the Stable and or the Rurad, \&ce. 25 cts. 
The Fruit, Flower, and Kitchen Garden.

By Patrick Neill, LL.D., F.R.S., adapted to the United States. \$1 25.

Ladies' Companion to the Flower Garden.

By Mrs. Loudon. Edited by A. J. Downing. \$1 25.

The Fruits and Fruit Trees of America.

$\begin{array}{lll}\text { Do. do. } & \text { do. } & \text { By A. J. Downing. } \$ 150 .\end{array}$

Dictionary of Modern Gardening.

By Geo. W. Johnston. Edited by David Landreth. $\$ 150$.

The Rose Fancier's Manual.

By Mrs. Gore. $\$ 150$.

Parsons on the Rose.

The Rose : its History, Poetry, Culture, and Classification. By S. B. Parsons. \$1 50.

Hovey's Fruits of America.

Containing richly colored Figures and full Descriptions of all the Choicest Varieties cultivated in the United States, in 12 numbers. $\$ 12$.

History, 'Treatment and Diseases of the Horse, With a Treatise on Draught, and Copious Index. \$2.

Rural Economy,

In its Relations with Chemistry, Physics, and Meteorology. By J. B. Boussingault. Translated, \&c., by George Law. \$1.

Liebig's Agricultural Chemistry.

Edited by Lyon Playfair, Ph.D, F.G.S, and William Gregory, M.D.. P.R.S.E. \$1.

The Modern System of Farriery,

As Practised at the Present Time at the Royal Veterinary College, and from Twenty Years' Practice of the Author, George Skevington, M.R.V C. $\$ 5$.

\section{Ewbank's Hydraulics:}

A Descriptive and Historical Account of Hydraulic and other Machines for Raising Water. \$2 50.

The Fruit Garden.

By P. Barry. $\$ 125$.

The American Fruit Culturist;

Containing Directions for the Culture of Fruit Trees in the Nursery, Orchard, and Gar. den. By John J. Thomas. \$1.

\section{The Rose Manual.}

By Robert Buist. $75 \mathrm{cts}$.

The Plants o: Boston and Vicinity.

By Jacob Bigelow, M.ID, $\$ 150$ 
The Indian Meal Book;

Comprising the bess Receipts for the Preparation of that Article. By Miss Leslie. 25 ct.

The Horse's Foot,

And How to Keep it Sound. By William: Miles. $25 \mathrm{cts}$.

Catechism of Agricultural Chemistry and Geology. By J. F. W. Johnston. $25 \mathrm{cts}$.

Chemistry Applied to Agriculture.

By Le Count Chaptal. 50 cts

British Husbandry.

Three Vols. and Supplement. \$5.

Loudon's Arboretum.

Eight Vols. \$25.

Loudon on Gardening.

Loudon's Encyclopedia of Gardening. $\$ 10$.

Loudon on Agriculture.

Loudon's Encyclopedia of Agriculture. $\$ 10$.

Loudon on Trees, \&c.

Loudon's Encyclopedia of Trees, Shrubs \&c.

Loudon on Plants, \&c.

Loudon's Encyclopedia of Plants, \&c.

The Farmer's Library.

Two vols. 8vo. English. \$5.

The Farmer's Dictionary.

By D. P. Gardner. $\$ 150$.

Practical Treatise on the Grape Vine.

By J. Fisk Allen. Boards, $\$ 1$; paper, 88 ots.

Practical Treatise on the Veterinary Art.

By J. Bridds. $75 \mathrm{cts}$.

Sheep Husbandry.

By Henry S. Randall. $\$ 125$.

Agricultural Chemistry.

By Justus Liebig. Cloth, $\$ 1$; cheap edition, 25 cts.

Animal Chemistry.

By J. Liebig. Cloth, 50 cts. ; cheap ed. paper, 25 ets.

Liebig's Complete Works, 


\title{
AGRICULTURAL IMPLEMENTS AND MACHINERY,
}

\author{
Suited to all Countries.
}

\section{FIELD AND GARDEN SEEDS.}

\author{
FAR IIE IE, PLAN'TERSANDMELCHANTS
}

WILL FIND AT THE

\section{AGRICULTURAL WAREHOUSE}

or

\section{A. B. ALLEN \& Co.,}

\section{9 \& 191 WATER STREET, New York,}

The largest assortment in America of tools and machines suited to general culture: Most of the implements sold by them, are manufactured in their own machine shop, under the direct supervision of one of the firm, where the best of seasoned timber only is used, with iron, steel and other materials of the first quality.

Plows.-Of these we keep constantly on hand upwards of ONE HUNDRED different patterns, suitable for breaking up new ground, meadows, swamps, stubble, corn, cotton, rice and sugar lands. Also, a great variety of harrows, cultivators, cotton sweeps, rollers, seed soweirs, corn planters, grain cradles, hay and straw cutters, corn shellers, grain mills, shovels spades, hoes, scythes, rakes, wheels, wagons, carts. wheelbarrows, pumps, road scrapers, axes, chains, \&c.

Horse Powers. - The Railway or Endless Chain, Taplin's Circular, and other kinds, suitable for one to eightthorses. Threshers, Fan Mills, and Smut Machines.

Steam Engines, for farm and other purposes.

Sugar IIills, Rice and Coffee Hullers, Rice Threshers, and Cotton Gins.

rapioca Machines, for grating the Yuca, Mtandioca and other farinaceous roots for making sago, tapioca, starch, \&ce.

Portable Sav Mrills, Wind Mills, Grain Mills, Pumps for WVells, Mines, and Irivating.

Reaping and MYtring. Machines, Horse and hand Hay Rakes.

Castings for Plows and all Agricultural Machinery.

Horticultural Tools, embracing all suitable for the kitchen, and flower garden, trimming shrubbery, mowing lawns, \&c.

\section{SEEDS FOR THE FIELD AND GARDEN.}

These are imported directly from Europe, or grown expressly for us in the United States. They are fresh and of the best nualities.

Fertilisers.-Peruvian Guano, Poudrette, Plaster of Paris, Bone Dust, and Phosphate of Lime.

\section{IMFROVED STOCK.}

Durham, Devon, and other cattle ; Cotswold, Leicester, Southdown, Merino and Saxon Sheep; Suffolk, Lincoln, and Berkshire Swine.

A Descriptive, Pictorial Catalogue of over 100 pages, will be given, on application from customers, or sent to them by mail, on enclosing four letter stamps, to pre-pay postage, as requirted by the present post-office law.

A. B. ALLEN \& Co., 189 and 191 Water st. New York. 


$$
\text { - }
$$






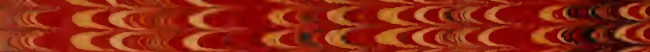

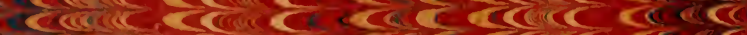

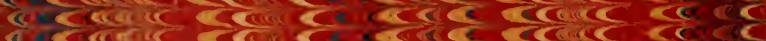
a cumb एक

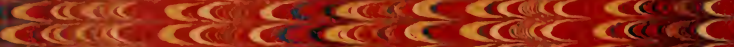

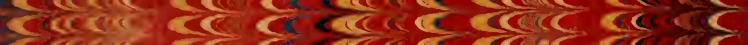

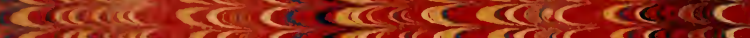

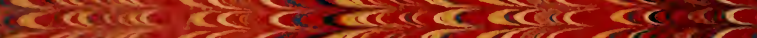

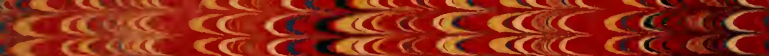

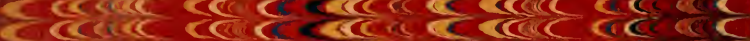

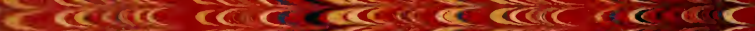

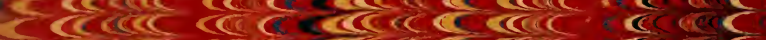

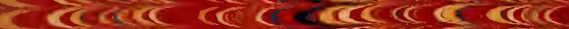

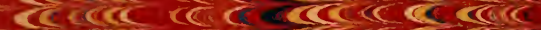

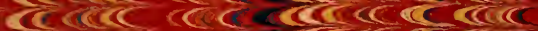

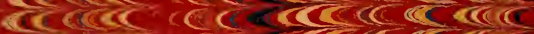

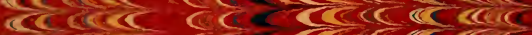
ce core

तC बतs

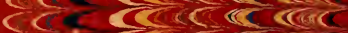

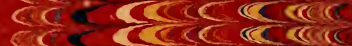

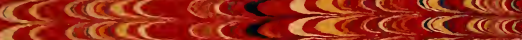

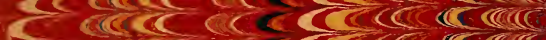

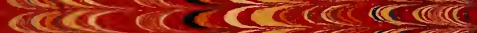

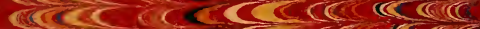

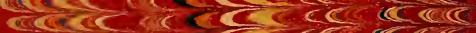

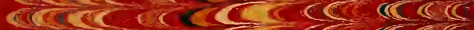
बत्व

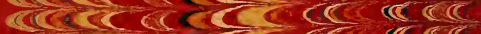

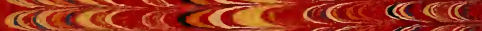

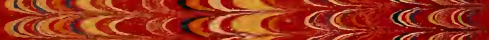

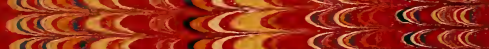

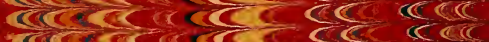

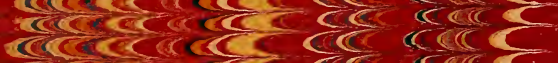

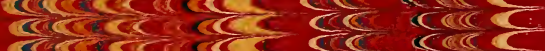

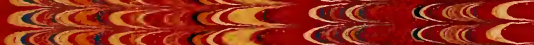

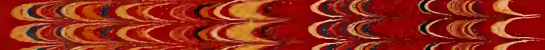

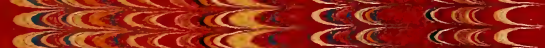

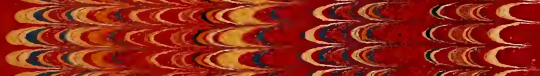

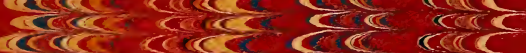

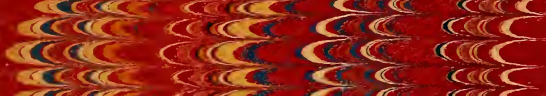
स्वर्त

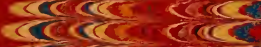
दलare बare

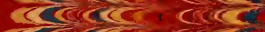
लencerent

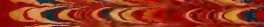
cerere ciré

करerere ense

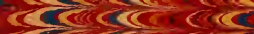

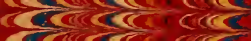

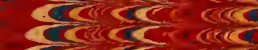
खं बह ए

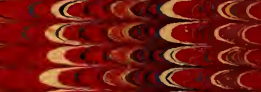
तs

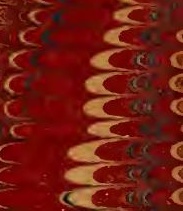
बंर है: esicts

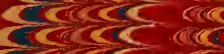
तicse

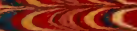
(ख)

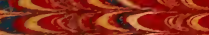
cerces (t) होicter क्वेत्रता है। mar सर

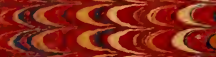

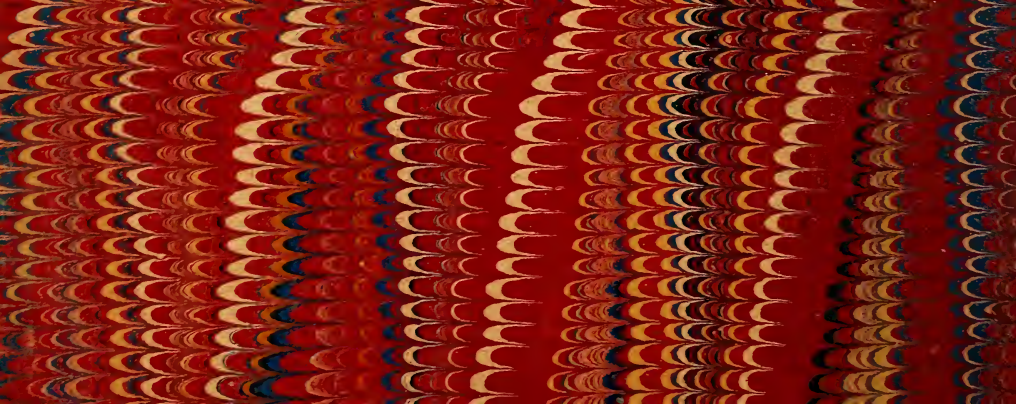
cres CR tre can

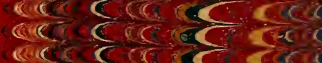

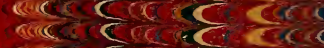

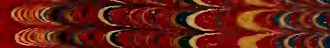
बतes $c$ हरें

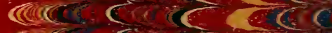

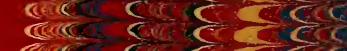

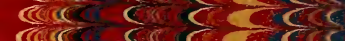

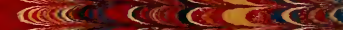
बलe cत करे है। बare Sce ST sere coses

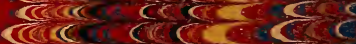
बices तecce

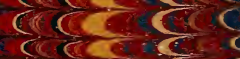
बलिख कार $15 \frac{c}{5}$ caresces बलmencen कencesen $\frac{1}{2}$ त्वलeri

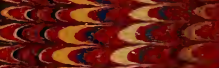
है 


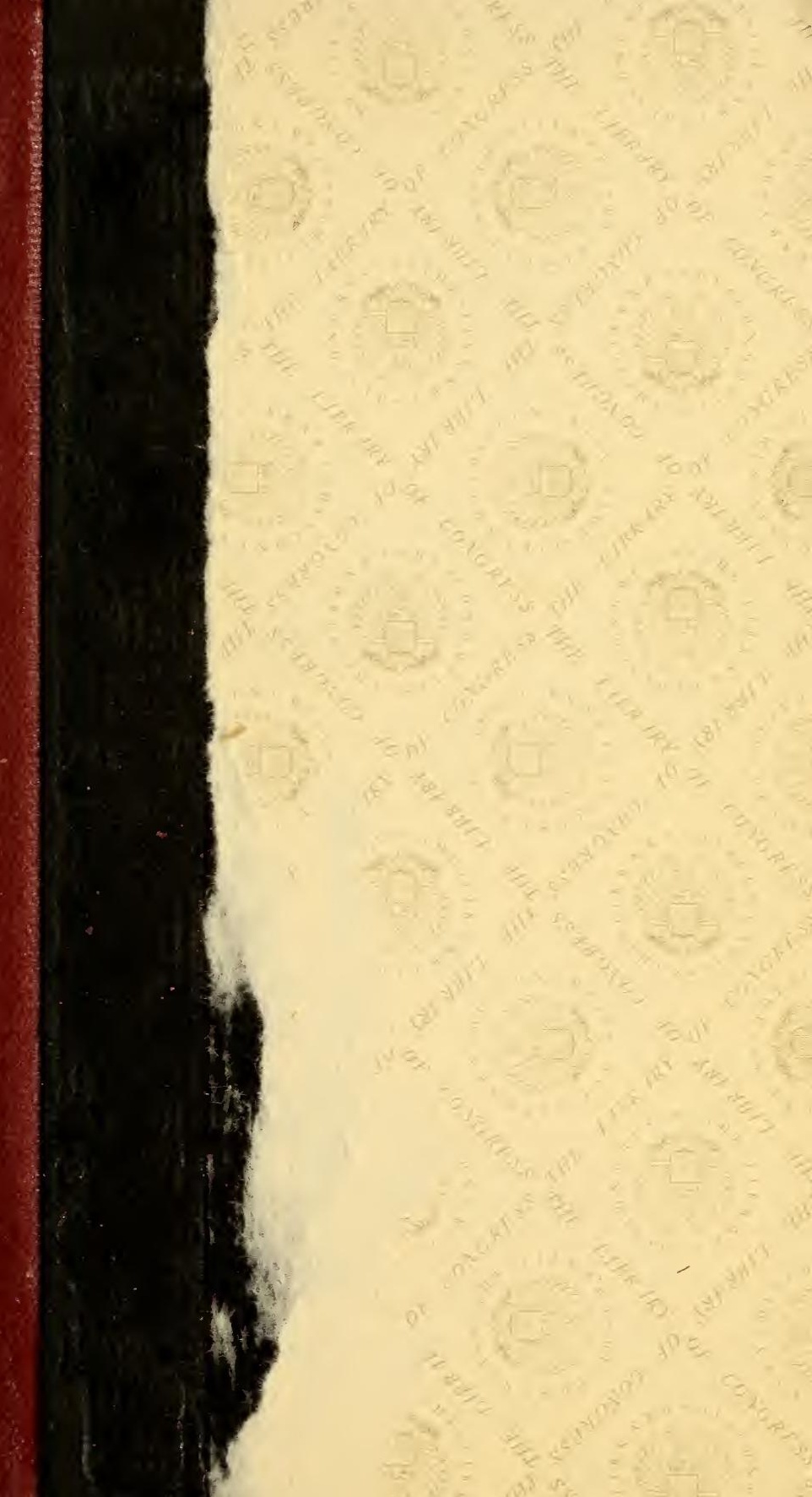




\section{LIBRARY OF CONGRESS \\ |||||||||||||||||||||||||||||||||||||||||||||||||||||||

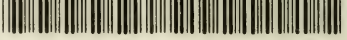

\section{6}

